UNIVERSIDADE DE SÃO PAULO

FACULDADE DE FILOSOFIA, LETRAS E CIÊNCIAS HUMANAS

DEPARTAMENTO DE CIÊNCIA POLÍTICA

PROGRAMA DE PÓS-GRADUAÇÃO EM CIÊNCIA POLÍTICA

CRISTIANE RACHEL PIRONI

Igualdade política e financiamento de campanhas eleitorais

v.1

São Paulo

2008 
UNIVERSIDADE DE SÃO PAULO

FACULDADE DE FILOSOFIA, LETRAS E CIÊNCIAS HUMANAS

DEPARTAMENTO DE CIÊNCIA POLÍTICA

PROGRAMA DE PÓS-GRADUAÇÃO EM CIÊNCIA POLÍTICA

\section{Igualdade política e financiamento de campanhas eleitorais}

Cristiane Rachel Pironi

Dissertação apresentada ao Programa de PósGraduação em Teoria Política do Departamento de Ciência Política da Faculdade de Filosofia, Letras e Ciências Humanas da Universidade de São Paulo, para a obtenção do título de mestre em Ciência Política.

Orientador: Prof. Dr. Álvaro de Vita

v.1

São Paulo

2008 
AUTORIZO A REPRODUÇÃO E DIVULGAÇÃO TOTAL OU PARCIAL DESTE TRABALHO, POR QUALQUER MEIO CONVENCIONAL OU ELETRÔNICO, PARA FINS DE ESTUDO E PESQUISA, DESDE QUE CITADA A FONTE.

Ficha de catalogação 


\section{FOLHA DE APROVAÇÃO}

Cristiane Rachel Pironi

Igualdade política e financiamento de campanhas eleitorais

Dissertação apresentada ao Departamento de Ciência Política da Universidade de São Paulo para obtenção de título de mestre.

Área de concentração: Teoria Política

Aprovado em

Banca examinadora

Prof. Dr.

Instituição Assinatura

Prof. Dr.

Instituição Assinatura 
Ao meu pai, por ter me ensinado a virtude da força.

Á minha mãe, por toda a compreensão.

Á tia Zélia pelo apoio incondicional. 


\section{Agradecimentos}

O trabalho acadêmico parece ser extremamente solitário. No entanto, sem o apoio de todos que convivem com o pesquisador, a realização de um estudo satisfatório se faz praticamente impossível.

Agradeço, especialmente, ao Prof. Dr. Álvaro de Vita, por ter sido orientador no que a palavra pode carregar de mais nobre, por toda a compreensão, respeito e humanidade com que sempre tratou seus orientandos. Agradeço por toda a confiança depositada em meu trabalho, por estar pronto a responder todas as dúvidas e questionamentos e por apontar novos horizontes e desafios, essenciais para a qualidade deste trabalho e para meu desenvolvimento como pesquisadora. Muito obrigada.

Agradeço ao Prof. Dr. Cícero Araújo e ao Prof. Dr. Wagner Pralon Mancuso, ambos da Universidade de São Paulo, pela leitura atenta de meu trabalho e pelas sugestões de extrema importância, tanto durante as disciplinas por eles ministradas quanto por ocasião de suas participações em minha banca de qualificação.

Agradeço, também, ao Prof. Dr. Bruno Wilhelm Speck, da Universidade de Campinas, e à colega Adla Bourdoukan, da Universidade de São Paulo, pela indicação de bibliografia ao longo de meu trabalho. Agradeço ao Prof. Dr. Denilson Luís Werle, da Universidade São 
Judas Tadeu, pela leitura atenta de meu trabalho e pelas sugestões dadas por ocasião do V Simpósio da Pós-graduação em Ciência Política da Universidade de São Paulo.

Agradeço, do fundo do meu coração, aos meus pais, José e Alice Pironi por absolutamente tudo em que me tornei e tudo que conquistei.

Agradeço à tia Zélia por ter sempre acreditado em meu potencial; à minha irmã Iná, pelo companheirismo e apoio de sempre; e ao tio Chico, à minha sobrinha Nathália e ao meu sobrinho Marcelo, por fazerem minha vida mais feliz. Agradeço ao tio João e à tia Hélia pelo estímulo e força.

Agradeço à Cida e à Catarina pelo suporte. Sem a ajuda delas para organizar minha vida pessoal, sobretudo nesta reta final, tudo teria se tornado muito mais difícil.

Agradeço aos meus queridos amigos Alexsander da Silva, Alysson Juliati, Ana Fernandes, Ana Paula Edington, Anna Cláudia Guirro, Anna Paula Greca, Andréia de Castro, Cássio Ferreira, Cristiane Borges, Daiane Vieira, Débora Veiga, Edemilson Mello, Elisete Neves, Fernando Santhiago, Gustavo Santos, Luciana Hoff, Marcio Barreto, Márcio Siqueira, Maria Monteiro, Rosely Guarnieri, Sabrina Galvão, Samuel Vidilli, Thiago Passos e Wesley de Almeida pelos momentos de diversão, leveza e alegria e pelo apoio em todas as minhas escolhas.

Agradeço à San Assumpção e Cláudia Marconi pela amizade acadêmica e pelo apoio. 
Agradeço aos amigos José dos Santos, Iria Melo, Marcel Carrilo, Bete Haga e Paulo Levi de Castro pelo apoio profissional.

Agradeço, também, ao pessoal do Departamento de Ciência Política da USP e, em especial à Rai e Vivian por estarem sempre a postos, com um sorriso no rosto e muita competência.

Agradeço ao Conselho Nacional de Desenvolvimento Científico e Tecnológico (CNPq) pela bolsa a mim concedida.

Muito obrigada a todos.

Cristiane Rachel Pironi 
PIRONI, C. R. Igualdade política e financiamento de campanhas eleitorais. 2008.

Dissertação (mestrado). Departamento de Ciência Política da Universidade de São Paulo, São Paulo, 2008.

\section{Resumo}

A delicada relação entre economia e política contida na questão do financiamento de partidos políticos e campanhas eleitorais vem ocupando um lugar central na agenda política das democracias de todo o mundo, e com a América Latina não poderia ser diferente.

Tomando como base as teorias da democracia e da justiça, esta dissertação procura analisar as formas de financiamento político existentes (público, privado e misto), tendo em vista a ameaça que a interferência do dinheiro na política pode acarretar à democracia e à manutenção do valor eqüitativo das liberdades políticas, no contexto das democracias contemporâneas.

Palavras-chave: teoria da justiça; democracia; financiamento político; valor eqüitativo das liberdades políticas, representação. 
PIRONI, C. R. Political equality and electoral campaign financing. 2008. Dissertação (mestrado). Departamento de Ciência Política da Universidade de São Paulo, São Paulo, 2008.

\begin{abstract}
The difficult relationship between economic power and democratic politics as it can be seen in political parties and electoral campaign financing issues, has been filling a central place in the political agenda of the democracies all over the world and it couldn't be different regarding Latin America.
\end{abstract}

Based on theories of democracy and justice, this dissertation analyses arrangements of political financing (public, private and mixed), dealing with the threat that the interference of money in politics might bring to democracy and to the maintenance of fair value of the equal political liberties, in the context of contemporary democracies.

Key-words: theory of justice; democracy; political financineg; equitative value of political liberties; representation. 


\section{SUMÁRIO}

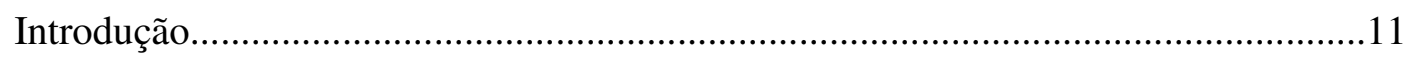

Capítulo 1: A discussão no campo da teoria da justiça..............................................19

1.1. A teoria da justiça de John Rawls e os dois princípios de justiça.......19

1.2. A importância da democracia para as liberdades políticas..................35

1.3. Participação política, democracia e distribuição....................................41

Capítulo 2: Representação e teoria democrática.......................................................50

2.1. Reflexões acerca da Representação Política e da Democracia Representativa

- há uma crise da representação?............................................................51

2.2. Democracia, poliarquia e igualdade política......................................91

Capítulo 3: O financiamento de partidos políticos e campanhas eleitorais................109

3.1. A influência dos grupos de interesse..............................................111

3.2. O financiamento político no Brasil e na América Latina...................119

3.3. O financiamento no Brasil - algumas características........................125

3.4. O problema do "caixa dois" e o "Mensalão".......................................133

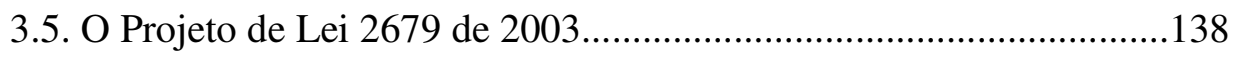


3.6. Argumentos contra e a favor de cada uma das formas de financiamento político...... 139

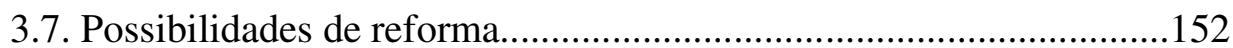

Considerações finais. 158

Referências bibliográficas. 167 


\section{Introdução}

"O maior problema é que, hoje, as campanhas eleitorais são feitas de um jeito que torna praticamente impossível não haver alguma ilicitude', comenta um assessor petista. As campanhas são imensamente caras. A maior parte dos deputados gasta mais de R\$ 1 milhão para se eleger. Nem tudo é registrado. Todos os escândalos recentes na política de alguma forma têm a ver com o financiamento de campanhas. O impeachment do presidente Fernando Collor ocorreu como desdobramento de uma investigação sobre Paulo César Farias, tesoureiro da sua campanha. O ex-ministro da Agricultura José Eduardo Andrade Vieira acusou a existência de um caixa dois na campanha do presidente Fernando Henrique Cardoso. A ex-governadora do Maranhão Roseana Sarney desistiu de ser a candidata do PFL à Presidência da República depois que a Polícia Federal descobriu R \$ 1,3 milhão arrecadados de forma irregular para a sua campanha. E o candidato do PSDB, José Serra, vê-se às voltas com problemas envolvendo o tesoureiro de suas campanhas anteriores e ex-diretor do Banco do Brasil Ricardo Sérgio de Oliveira. (LAGO, 2002)

Foi na campanha de Azeredo ao governo de Minas em 1998 que Marcos Valério criou o engenhoso esquema de camuflar com empréstimos bancários as doações de 'caixa dois' de empreiteiras, assim como dinheiro desviado de contratos de publicidade de órgãos públicos. Canalizados para sua empresa, a SMP\&B, esses recursos pagaram a caríssima campanha do PSDB e seus aliados. Quatro anos depois, Marcos Valério proporia o mesmo esquema à coalizão PT-PL para financiar a campanha de 2002. (KUCINSKI, 2007).

Uma tese de doutorado defendida na USP (Universidade de São Paulo) neste mês [outubro de 2007] pelo cientista político Leonardo Sakamotto vê uma 
relação entre a morosidade na apreciação dos projetos anti-escravagistas e as doações de campanha eleitoral. Segundo ele, empresas agropecuárias acusadas de trabalho escravo, seus donos e parentes fizeram doações nas eleições de 2002 e 2004 que ajudaram a eleger dois governadores, cinco deputados federais, três deputados estaduais, três prefeitos e um vereador. Ele apontou ainda três deputados federais, um estadual e três prefeitos entre proprietários ou parentes de donos de fazendas autuadas por suposto trabalho escravo. (VALENTE, 2007)

Líderes políticos do chamado Primeiro Mundo que fizeram história na década de 90 foram contaminados, como o ex-primeiro-ministro alemão Helmut Kohl (Partido Democrata-Cristão, CDU), conhecido como o "pai da reunificação" da Alemanha após a queda do muro de Berlim. Kohl foi acusado e acabou admitindo ter recebido para o caixa do CDU a bolada de US\$ 1,2 milhão - uma contribuição não computada na prestação de contas de seu partido. Na França, o presidente Jacques Chirac teve seu nome envolvido em um escândalo de financiamento de campanha, em 1996, protagonizado por Jean-Claude Méry, arrecadador de contribuições para o partido gaullista (RPR). Nos Estados Unidos, o escândalo da gigante Enron acabou revelando sua atuação suspeita como grande financiadora em campanhas políticas. A influência do dinheiro em eleições nos EUA sempre foi notória e esse escândalo acabou forçando o governo a promover mudanças na legislação eleitoral. Por isso, o presidente George W. Bush promulgou, em 2002, uma lei que reforma o financiamento das campanhas com o intuito de diminuir a força das verdinhas na eleição, implementando limitações às doações privadas. (COSTA; VILAS, 2004)

Os trechos acima, publicados na mídia impressa, apontam um tema cada vez mais debatido nas democracias contemporâneas: o financiamento de partidos políticos e campanhas eleitorais. São poucos os países que não têm em sua história algum escândalo 
relacionado ao financiamento político "seja em função da suspeita de recursos de origem ilícita, da violação de limites estabelecidos para o financiamento, da prática de doações não registradas ou, em casos mais graves, da suspeita de que as doações estejam vinculadas a favores por parte dos representantes políticos" (SPECK, 2005, p.123). De fato, como podemos observar nos excertos apresentados, as questões relacionadas às irregularidades encontradas neste terreno não são privilégio do Brasil: democracias de países considerados de primeiro mundo, como Alemanha, França e Estados Unidos, também têm sofrido sérios golpes no que se refere à lisura de seus processos de financiamento político, colocando a questão no centro de suas agendas políticas.

O debate acerca da questão do financiamento político passa pela questão da representação política e dos partidos. No período anterior ao surgimento dos partidos políticos, os próprios candidatos financiavam suas campanhas, reduzindo a participação política a uma pequena parcela economicamente privilegiada da população não favorecendo, assim, a igualdade no campo político. Ainda hoje esta forma de financiamento ocupa importante espaço nas campanhas de diversos países, porém, com o surgimento dos partidos políticos esta modalidade de financiamento teve de dividir espaço com outras modalidades de financiamento. Num primeiro momento os partidos políticos arrecadavam fundos junto aos seus membros (SPECK, 2005, p.125), e a sua única fonte de receita era o financiamento privado.

A partir do século XX, começaram a surgir debates sobre os perigos do financiamento exclusivamente privado, no que se refere à dependência dos representantes políticos em relação ao poder econômico, implicando uma maior representação, por parte dos eleitos, dos interesses de seus financiadores do que dos cidadãos de uma maneira geral. No período pós Segunda Guerra Mundial, diversas constituições alçaram os partidos 
políticos à posição de "instituição fundamental da democracia", e esta constitucionalização dos partidos políticos implicou a obrigação do Estado para com a garantia do bom funcionamento e manutenção desta instituição. Deste modo, o financiamento político público originou-se no inicio do século XX - mais especificamente em 1928, no Uruguai e disseminou-se durante a segunda metade do século $\mathrm{XX}$, sobretudo dentre países da América do Sul e da Europa. No caso do Brasil, o financiamento público surgiu em 1965, sob a forma do fundo partidário. (BRAGA; BOURDOUKAN, 2008). Junto ao surgimento do financiamento público surgiu, também, o financiamento misto (RUBIO, 2005).

Haja vista os escândalos associados ao financiamento privado de campanhas, recentemente o debate acerca da proposta de um financiamento de campanhas integralmente público tem ganho força no cenário político. Sobre isso, observemos este trecho de reportagem do jornal Folha de São Paulo, de 25 de janeiro de 2009, sobre o aniversário de 25 anos das Diretas Já:

O autor de História no Brasil, o cientista político Jairo Marconi Nicolau diz que o principal desafio do futuro é a questão do financiamento e da falta de transparência nas contas. "O desafio que afeta a democracia é o controle de gastos, o papel do dinheiro na política. E há uma visão reducionista de que a única alternativa seria o financiamento público exclusivo", afirma Nicolau. Nos últimos anos, grandes escândalos tiveram vinculação direta ou indireta com o financiamento das campanhas, entre eles o impeachment de Collor e o mensalão, em 2005, quando o presidente Lula insinuou que o caixa dois eleitoral ocorre "sistematicamente". (MELLO; BOMBIG, 2009, p.A4)

A proposta do financiamento público exclusivo encontra subsídio no trabalho de alguns importantes teóricos políticos, em especial John Rawls. De acordo com Rawls, a influência da economia na política deve ser limitada a fim de se garantir o valor eqüitativo 
das liberdades políticas, associado ao primeiro ${ }^{1}$ princípio de justiça. Segundo o autor, esta garantia permite que o valor das liberdades políticas seja igual para todos os cidadãos, independentemente de sua posição socioeconômica, permitindo que todos possuam oportunidade eqüitativa de ocupar cargos públicos e afetar o resultado das eleições. Sem esta garantia os detentores de mais meios sócio-econômicos poderiam unir-se e excluir os detentores de menos meios socioeconômicos. O que verificamos em grande parte das democracias ocidentais é a incapacidade dos sistemas constitucionais de assegurar o justo valor das liberdades políticas, sobretudo, devido à concentração de renda. A má distribuição de renda causa diversos males nas sociedades nas quais ela se instala, dentre eles a influência do dinheiro na política ocupa lugar de destaque, com os que dispõem de maior riqueza e melhores posições sociais controlando a vida política e promulgando legislações e políticas sociais que promovam seus interesses particulares (Rawls, 2003).

O financiamento público é visto por Rawls como uma forma de assegurar o valor eqüitativo das liberdades políticas. No entanto, o autor não desenvolve esta idéia. Ele diz em Justiça como eqüidade - uma reformulação:

Não tenho como analisar aqui qual a melhor maneira de realizar esse valor eqüitativo nas instituições políticas. Apenas parto do princípio de que existem modos institucionais viáveis de tornar isso compatível com o âmbito central de aplicação das outras liberdades básicas. Reformas nesse sentido costumam envolver coisas como o uso de fundos públicos para eleições e restrições às

\footnotetext{
${ }^{1}$ Em Justiça como eqüidade - uma reformulação, John Rawls nos apresenta os dois princípios de justiça por ele desenvolvidos de maneira reconfigurada. Friso que nesta dissertação tratarei especificamente do primeiro princípio de justiça:
}

\section{Primeiro princípio}

Cada pessoa tem o mesmo direito irrevogável a um esquema plenamente adequado de liberdades básicas iguais que seja compatível com o mesmo esquema de liberdades para todos. (RAWLS, 2006, p.60). [Grifo meu] 
contribuições de campanhas, a garantia de um acesso eqüitativo aos meios de comunicação, e algumas regulamentações da liberdade de expressão e de imprensa (mas não restrições que afetem o conteúdo da expressão). (...) Um dos objetivos do ajuste dessas liberdades básicas é dar a legisladores e partidos políticos independência em relação a grandes concentrações de poder econômico e social privado numa democracia de propriedade privada. (RAWLS, 2003, p.212) [Grifo meu].

Rawls apenas aponta a questão do financiamento de campanhas, chamando atenção para a importância do tema, mas não aprofunda a discussão.

A questão geral da qual trata esta dissertação é: como podemos assegurar que o método democrático seja empregado de modo a fomentar a justiça social ou reduzir a injustiça social? E, mais especificamente, procurarei traçar um quadro geral do debate acerca do financiamento de partidos políticos e campanhas eleitorais no que se refere à bibliografia empírica sobre o tema. O financiamento público exclusivo seria a melhor alternativa para que se verifique a promoção do valor eqüitativo das liberdades políticas? Em que direção deve seguir uma reforma política que tenha como objetivo, senão anular, pelo menos limitar de maneira satisfatória os efeitos negativos da influência do dinheiro na esfera política, de acordo com esta bibliografia? São estas as questões que esta dissertação procurará responder.

Para tanto, realizarei uma análise da discussão no campo da teoria da justiça sobretudo John Rawls - sobre o tema. Apresentarei a idéia dos dois princípios de justiça formulados por John Rawls, concentrando-me no primeiro princípio de justiça, onde inserem-se as liberdades políticas; procurarei justificar a importância do valor eqüitativo das liberdades políticas e, por fim, tratarei da questão da importância da democracia para as liberdades políticas. Além disso, apresentarei onde o financiamento político insere-se nesta 
bibliografia teórica como um dos pontos importantes a serem trabalhados na trajetória rumo a uma sociedade democrática mais justa.

Em seguida tratarei do debate acerca da teoria da democracia representativa e da representação. Hoje vemos disseminada na sociedade a idéia de que a representação política está passando por uma crise e, para verificar se esta afirmação é verdadeira, analisarei a bibliografia acerca da crise da representação, sobretudo Bernard Manin. Se o que está em curso nas sociedades democráticas contemporâneas for realmente uma crise do governo representativo, evidentemente seria preciso repensar outras formas de governo. Porém, se esta crise não for verificada, podemos considerar que, para que possamos obter resultados mais justos do processo democrático, seja suficiente que pensemos em reformas institucionais que nos permitam alcançar este objetivo. Buscarei respaldo para esta afirmação na reflexão de Robert A. Dahl. Este debate é importante pelo fato de a questão do financiamento de campanhas eleitorais e partidos políticos, abordada nesta dissertação, existir somente porque vivemos numa democracia representativa, onde representantes e partidos políticos - objetos do financiamento - constituem elementos essenciais para a prática da política.

Por fim, tratarei da questão do financiamento de partidos políticos e campanhas eleitorais em si, apresentando o debate atualmente desenvolvido sobre o assunto junto à bibliografia empírica. Focarei no caso brasileiro e da América Latina. Procurarei traçar um quadro do financiamento político na região, apresentando suas e, por fim, apresentarei as formas de financiamento atualmente existentes, seus pontos negativos e positivos e procurarei identificar qual o modelo de financiamento político defendido por alguns dos maiores estudiosos do tema na região, bem como os pontos que devem ser melhor 
trabalhados para que possamos gozar de um financiamento político mais justo e livre de ilegalidades.

Deste modo, pretendo contribuir para o debate acerca da garantia da justiça social e da igualdade política nos sistemas democráticos e, mais especificamente, para a compreensão do valor eqüitativo das liberdades políticas e da melhor configuração dos sistemas de financiamento político para que este valor eqüitativo não seja solapado pela influência do poder econômico na esfera política.

Pelo fato de a questão do financiamento de partidos políticos e campanhas eleitorais estar no centro do debate político atual, e pelo fato de encontrarmos subsídios na obra de um importante teórico como John Rawls sobre a importância do assunto, o objetivo deste estudo se faz de extrema relevância, procurando aprofundar o debate sobre a reforma política, no tocante ao sistema de financiamento político à luz da teoria da justiça. 


\section{Capítulo 1: A discussão no campo da teoria da justiça}

\subsection{A teoria da justiça de John Rawls e os dois princípios de justiça}

Em seu trabalho Uma Teoria da Justiça, publicado em 1971, John Rawls nos apresenta uma teoria da justiça que tem como objetivo ser uma alternativa às concepções utilitarista clássica e intuicionista da justiça ${ }^{2}$, que então dominavam o cenário da tradição filosófica no contexto da filosofia política anglo-saxônica. Rawls deixa claro que a justiça é a "virtude primeira das instituições sociais", sendo sua teoria aplicada às instituições e não aos indivíduos.

A concepção de justiça apresentada por Rawls - a justiça como eqüidade ${ }^{3}$ generaliza e leva a uma concepção superior a teoria do contrato social - desenvolvida, dentre outros, por Locke, Rousseau e Kant -, sendo o objeto do acordo original os princípios de justiça a serem aplicados à estrutura básica ${ }^{4}$ da sociedade (RAWLS, 1993, p.30). Tal acordo seria firmado entre as partes ${ }^{5}$ envolvidas na chamada "posição original”,

\footnotetext{
${ }^{2}$ As concepções utilitarista clássica e intuicionista são desenvolvidas, respectivamente, nos parágrafos 5 e 7 de Uma Teoria da Justiça.

${ }^{3}$ A justiça como equiidade não é uma doutrina religiosa, filosófica ou moral abrangente, que possa ser aplicada a todos os temas e que abarque todos os valores, e nem deve ser compreendida como "a aplicação de uma doutrina desse tipo à estrutura básica da sociedade, como se essa estrutura não tratasse de mais um tema a ser tratado por essa estrutura abrangente" (RAWLS, 2003, p.19). Logo, nem a filosofia política e nem a teoria da justiça como eqüidade são, neste caso, filosofia moral aplicada, pois a primeira possui suas características e problemas distintos, e a segunda "é uma concepção política de justiça para o caso especial de uma estrutura básica de uma sociedade democrática contemporânea" (RAWLS, 2003, p.19), restringindo-se a apenas uma parte do campo da moral: a política.

${ }^{4}$ A estrutura básica da sociedade (ou seja, a forma pela qual as instituições mais importantes da sociedade constituição política e as principais estruturas econômicas e sociais - distribuem direitos e deveres fundamentais e determinam a divisão dos benefícios obtidos através da cooperação social) seria o objeto da justiça pelo fato de suas consequiências serem profundas e estarem presentes desde o início.

${ }_{5}^{5}$ As partes envolvidas neste processo não são indivíduos reais e devem ser interpretadas como pessoas ("hipotéticas") morais livre e iguais que sabem muito pouco sobre si mesmas. (RAWLS, 2000, p.325)
} 
que teria como fim a escolha dos princípios da justiça. Rawls nos diz que a posição original é hipotética e não-histórica e, portanto, não se trata de uma situação histórica concreta ou de um estado cultural primitivo (RAWLS, 2003, p.33). Além disso, a deliberação das partes na posição original não corresponde à aplicação dos princípios resultantes desta numa sociedade real. Isso se dá pelo fato de que

\begin{abstract}
o acordo feito na posição original representa o resultado de um processo racional de deliberação em condições ideais e não-históricas que expressam certas exigências razoáveis. Não existe uma forma praticável de concretizar este processo deliberativo e de assegurar que se conforme às condições impostas. Portanto, quando o resultado é alcançado pela deliberação das partes em ocasiões reais, ele não pode ser corroborado pela justiça procedimental pura. Em vez de se basear em acordos reais, é preciso chegar ao resultado raciocinando-se de forma analítica, isto é, a posição original deve ser caracterizada com exatidão suficiente para que seja possível descobrir, que concepção de justiça é favorecida pelo equilíbrio de razões. O conteúdo da justiça deve ser descoberto pela razão, isto é, pela resolução do problema do acordo que se apresenta na posição original. (RAWLS, 2000, p.326)
\end{abstract}

A escolha dos princípios da justiça deveria ser feita sob certas condições específicas. A condição essencial para o firmamento deste acordo é que as partes nele envolvidas, por um lado, encontrem-se em posição de igualdade a fim de que sejam evitadas posições e decisões que viessem a favorecer os detentores de determinadas características naturais ou sociais e por outro, tenham pleno conhecimento do fato de que a sociedade na qual estão inseridos está submetida ao contexto da justiça e às suas respectivas conseqüências, bem como conheçam fatos gerais, ou seja, compreendam os assuntos políticos, econômicos, a organização social e as leis da psicologia (RAWLS, 1993, p.121; 2000, p.325). Para que esta situação ideal seja garantida, Rawls lança mão do conceito de "véu de ignorância". Este véu permitiria que as partes envolvidas no processo não tivessem

\footnotetext{
${ }^{6}$ A posição original é o status quo que garante que todos os acordos nele alcançados sejam eqüitativos, decorrendo daí a expressão "justiça como eqüidade” (Rawls, 1993, p.33).
} 
conhecimento de sua posição na sociedade, de suas fortunas naturais (nem sequer de suas características psicológicas teriam eles conhecimento) e sociais (eles desconheceriam o grau de civilização, cultura e riqueza que conseguiram atingir) e das circunstâncias particulares da sociedade na qual estão inseridos (não possuem informações sobre recursos naturais, bens de produção grau de desenvolvimento tecnológico desta sociedade), pois as questões de justiça social surgem tanto dentro de uma mesma geração quanto entre gerações, o que justificaria esta ampla restrição ao conhecimento das partes envolvidas. As partes “devem escolher princípios cujas conseqüências estejam dispostos a viver, seja qual for a geração a que pertençam" (RAWLS, 1993, p.121; 2000, p.325). Deste modo, o "véu de ignorância" garante a eqüidade e neutralidade das partes no processo, garantindo a imparcialidade moral do mesmo.

Os dois princípios de justiça, apontados por Rawls em Uma Teoria da Justiça, são os seguintes:

\footnotetext{
Primeiro princípio

Cada pessoa deve ter um direito igual ao mais amplo sistema total de liberdades básicas iguais que seja compatível com um sistema semelhante de liberdades para todos.

Segundo princípio

As desigualdades econômicas e sociais devem ser distribuídas por forma a que, simultaneamente:

a) redundem nos maiores benefícios possíveis para os menos beneficiados, de uma forma que seja compatível com o princípio da poupança justa, e

b) sejam a conseqüência do exercício de cargos e funções abertos a todos em circunstâncias de igualdade equiitativa de oportunidades. (RAWLS, 1993, p.239)
}

Dentre as liberdades básicas abarcadas pelo primeiro princípio, Rawls (1993, p.68) elenca as seguintes: liberdade política (votar e ocupar função pública), liberdade de expressão e reunião, liberdade de consciência e de pensamento, liberdade da pessoa 
(psicológica e física), direito à propriedade pessoal e à proteção face à detenção e prisão arbitrárias. Estas são as liberdades que permitem que os cidadãos possam desenvolver as faculdades básicas que lhes permitam julgar a justiça da estrutura básica da sociedade na qual estão inseridos, bem como suas políticas sociais (RAWLS, 2003, p.64). Estas liberdades devem ser iguais para todos e somente podem ser limitadas ou objeto de compromisso nas situações em que entrem em conflito com outras liberdades básicas (RAWLS, 1993, p.68).

$\mathrm{O}$ segundo princípio se refere à distribuição de riqueza e rendimento e às organizações que aplicam as diferenças de autoridade e responsabilidade, e está dividido em duas partes. A primeira parte diz respeito ao princípio da diferença, para o qual a distribuição de riqueza não tem de ser igual, mas sim praticada de modo a beneficiar a todos. A segunda parte diz respeito à igualdade eqüitativa de oportunidades, para a qual as posições de autoridade e responsabilidade devem ser igualmente acessíveis a todos, gerando igualdade de oportunidades:

"pessoas igualmente talentosas e motivadas devem ter a mesma chance de alcançar posições desejadas, na medida em que isso é consistente com a igualdade de liberdades básicas; e de acordo com o princípio da diferença, as desigualdades atreladas àquelas posições devem trazer benefício para aqueles que se encontram em situação de maior desvantagem" (COHEN, 2003, p.89).

Rawls frisa, ainda, a ordenação serial dos princípios, tendo o primeiro princípio prioridade sobre o segundo, ou seja, violações das liberdades básicas não podem ser justificadas ou compensadas por maiores vantagens econômicas e/ou sociais (Primeira regra de prioridade). 
Esta formulação dos dois princípios da justiça respeita a duas regras de prioridade a seguir (RAWLS, 1993, p.239):

Primeira regra de prioridade: da liberdade, segundo a qual o primeiro princípio sempre prevalece sobre o segundo. Em outras palavras, perdas no âmbito das liberdades básicas não podem ser justificadas por ganhos de ordem econômica ou social, mas sim apenas em benefício das próprias liberdades.

Segunda regra de prioridade: da justiça sobre a eficiência e o bem-estar, segundo a qual o segundo princípio prevalece sobre os princípios da eficiência e da maximização da soma de benefícios, e o princípio da igualdade eqüitativa de oportunidades prevalece sobre o princípio da diferença.

Em seu livro Justiça como Eqüidade - uma Reformulação, publicado em 2002, Rawls faz uma reformulação dos princípios de justiça apresentados anteriormente em Uma Teoria da Justiça, reapresentado-os da seguinte maneira:

\section{Primeiro princípio}

Cada pessoa tem o mesmo direito irrevogável a um esquema plenamente adequado de liberdades básicas iguais que seja compatível com o mesmo esquema de liberdades para todos. [Grifo meu]

Segundo princípio

As desigualdades sociais e econômicas devem satisfazer duas condições: primeiro, devem estar vinculadas a cargos e posições acessíveis a todos em condições de igualdade eqüitativa de oportunidades; e, em segundo lugar, têm de beneficiar ao máximo os membros menos favorecidos da sociedade (o princípio da diferença). (RAWLS, 2003, p.60)

Nesta dissertação, no tocante à obra de John Rawls, trabalharei a questão das liberdades políticas inseridas no leque das liberdades básicas, concentrando-me no primeiro 
princípio da justiça ${ }^{7}$, onde se situam as revisões mais significativas realizadas por ocasião da confecção de Justiça como Eqüidade (2003).

O primeiro princípio de justiça aplica-se não somente à estrutura básica da sociedade (o segundo princípio também possui esta característica), como também ao que Rawls considera ser a constituição, quer seja ela escrita ou não. Algumas das liberdades, sobretudo as liberdades políticas iguais e a liberdade de pensamento e associação, devem ser garantidas por esta constituição, logo, deve haver um "poder constituinte" que deve ser adequadamente institucionalizado na forma de um regime que propicie o direito de votar e exercer mandato e nas cartas de direito. Logo, os princípios da justiça requerem um regime político democrático que seja embasado por uma constituição democrática (COHEN, 2003, p.92). Estes assuntos referem-se aos chamados elementos constitucionais essenciais, que são aqueles assuntos que demandam maior urgência para se alcançar um acordo político, dado o pluralismo que envolvem (RAWLS, 2003, p.65): o governo e a oposição devem concordar quanto a estes elementos constitucionais essenciais, pois é esta concordância que torna o governo legítimo. (RAWLS, 2003, p.69) Neste sentido, “a justiça como eqüidade [de Rawls] é para uma sociedade democrática" (Cohen 2003, p.87), que é aquela na qual os indivíduos são entendidos, em sua cultura política - a cultura política democrática -, como livres e iguais e que tenta concretizar esta idéia nas suas principais instituições. Em outras palavras, a cultura democrática é aquela comprometida com a idéia de cooperação social que é justa, sendo que a cooperação se dá entre pessoas que reconhecem umas às outras como sendo livre e iguais. Assim, a concepção política de justiça de Rawls se baseia num conjunto de idéias que seriam inerentes à cultura democrática, propiciando condição de

\footnotetext{
${ }^{7}$ De acordo com o autor, a reformulação do segundo princípio é apenas de ordem estilística. O segundo princípio de justiça de John Rawls não será analisado neste trabalho pelo fato de nosso foco principal ser o primeiro princípio.
} 
pluralismo, incluindo os principais pontos da constituição. Deste modo, mais do que um sistema de governo, uma sociedade democrática é caracterizada por condições de igualdade, e seus membros devem ser capazes de possuir senso de justiça, além de serem tratados pelas instituições básicas da sociedade com um igual respeito, independentemente de suas várias concepções de bem que venham a adotar. Neste tipo de sociedade não há julgamento de valor quanto ao que o indivíduo perseguirá como objetivo de vida e há distribuição eqüitativa de recursos sociais escassos, que permitam que cada um busque seus objetivos para que esta não seja apenas uma liberdade formal, mas sim efetiva.

Em Justiça como Eqüidade, Rawls (2003, p.68) aponta quatro razões para que haja distinção entre os elementos constitucionais essenciais englobados pelo primeiro princípio e as instituições de justiça distributiva englobadas pelo segundo:

(a) os dois princípios incidem sobre diferentes estágios da aplicação de princípios e identificam duas funções distintas da estrutura básica;

(b) é mais urgente estabelecer os elementos constitucionais essenciais ${ }^{8}$;

(c) é muito mais fácil decidir se os elementos essenciais foram realizados e;

(d) parece possível chegar a um acordo sobre quais devam ser esses elementos essenciais, não sobre cada detalhe, é claro, mas suas linhas gerais.

Sendo assim, o que diferencia o primeiro e o segundo princípio não é a questão política, uma vez que ambos os princípios expressam valores políticos, não apenas o primeiro. Ambos os princípios aplicam-se à estrutura básica da sociedade, a qual possui

\footnotetext{
${ }^{8}$ Aqui devemos abrir um parênteses para falar um pouco sobre o que viriam a ser os "elementos constitucionais essenciais" citados em (b), (c) e (d). Em seu ensaio, "Rawls on Constitucionalism and Constitutional Law", de 2003, Frank Michelman aponta as seguintes categorias como sendo elementos constitucionais essenciais: estrutura básica de governo (basic governmental structure); assegurar a essência das liberdades básicas - e isso deve ser tomado severamente (securing the core basic liberties - taken severally); igualdade formal de oportunidades (formal equiality of opportunity) e prover as "necessidades básicas" (provision for basic needs). Estes seriam assuntos para serem resolvidos legalmente no nível da constituição nacional, através da combinação do legislativo e judiciário ou alguma outra interpretação oficial, e esta "lei superior" devem prevalecer acima de qualquer ação contrária trazida à cabo por legislações majoritárias. (2003, p.402)
} 
duas funções coordenadas, estando cada um dos princípios relacionados a uma dessas funções: o primeiro princípio está relacionado com a função da estrutura básica de determinar e garantir as liberdades básicas iguais para todos os cidadãos, dentre elas o valor eqüitativo das liberdades políticas, relacionando-se com a aquisição e o exercício do poder político; e o segundo princípio está associado à função de prover as instituições de fundo da justiça social e econômica da maneira mais adequada para cidadãos livres e iguais. (RAWLS, 2003, p.67)

Os princípios da justiça são aplicados numa seqüência de quatro estágios ${ }^{9}$, quais sejam: (1) a adoção dos princípio de justiça por trás do véu de ignorância; (2) o estágio da convenção constituinte; (3) o estágio legislativo; e o (4) estágio em que as normas são aplicadas pelos governantes, seguidas pelos cidadãos e a constituição e as leis são interpretadas por membros do poder judiciário.

Deste modo, o primeiro princípio de justiça se associa ao segundo estágio: o da convenção constituinte. De acordo com Rawls (1993), as partes realizam a convenção constituinte com o objetivo de decidir sobre a justiça das diversas formas políticas e elaborar uma constituição, que deve respeitar as limitações impostas pelos princípios de justiça, definidos no primeiro estágio. O primeiro princípio encontra-se vinculado à garantia de liberdades básicas iguais ${ }^{10}$ - os elementos constitucionais essenciais - para todos os indivíduos e a um regime constitucional justo ${ }^{11}$. Evidentemente, em termos ideais, uma constituição justa deveria resultar de um processo justo, comprometido com a idéia de assegurar um resultado igualmente justo. Porém, no caso de um regime constitucional ou

\footnotetext{
${ }^{9}$ Os quatro estágios são analisados em Uma Teoria da Justiça, parágrafo 31 e em Justiça como Eqüidade, parágrafo 13.6.

${ }^{10}$ Dentre eles está o valor eqüitativo das liberdades políticas.

${ }^{11}$ Estando associado à aquisição e ao exercício do poder político.
} 
qualquer outra forma política, este ideal de justiça processual perfeita não pode ser realizado, restando-lhe a condição de justiça processual imperfeita, afinal,

\begin{abstract}
"é evidente que qualquer processo político exeqüível pode produzir um resultado injusto. De fato, não há qualquer sistema de regras para o processo político que garanta que não será adotada legislação injusta.” (RAWLS, 1993, p.165)
\end{abstract}

De qualquer maneira - como já foi dito anteriormente - o primeiro princípio de justiça aplica-se ao que podemos considerar ser a constituição, quer seja ela escrita ou não e, analisando esta constituição, seus dispositivos políticos e a maneira como eles funcionam na prática, é possível identificar o respeito ou não aos elementos constitucionais essenciais.

Ainda na referida seqüência de quatro estágios, o segundo princípio encontra-se associado ao terceiro estágio legislativo, no qual são promulgadas leis de acordo com o que a constituição admite e com o que exige e permitem os princípios de justiça. Assim, o segundo princípio encontra-se vinculado às instituições de fundo da justiça social e econômica - ou seja, ao tipo de legislação social e econômica observada -, exigindo igualdade eqüitativa de oportunidades para todos e, também, que as desigualdades socioeconômicas sejam governadas pelo princípio de diferença.

Enquanto os objetivos do segundo princípio possuem alcance difícil de ser observado e um escopo passível de várias divergências, verificar o alcance dos objetivos do primeiro princípio é algo muito mais palpável, além de serem estes objetivos passíveis de maior concordância dentre as partes envolvidas. Deste modo, o segundo princípio deve ser posto em prática no contexto de instituições de fundo que estejam de acordo com as exigências do primeiro princípio (RAWLS, 2003, pp. 64-65). 
Segundo Michelman (2003), a constituição é a mais alta lei existente num país nenhum outro ato legal, opinião ou decisão devem contrapô-la - e ela deve ser empregada, sobretudo, em casos de disputa. Ainda de acordo com Michelman a concepção de "justiça como eqüidade" de Rawls produz uma reconstrução racional da tradição constitucionaldemocrática capaz de resolver algumas questões crônicas e discordâncias internas à tradição. A linha de raciocínio de Rawls seria mais ou menos a seguinte:

(1) Uma concepção política de justiça para a estrutura básica de uma sociedade democrática é desenvolvida a partir de idéias fundamentais que podem razoavelmente serem vistas como tendo sido delineadas a partir da cultura de cada sociedade.

(2) A concepção particular de justiça como eqüidade tem sido construída a partir de um conjunto particular de idéias fundamentais extraídas da cultura pública de um estado democrático. Entretanto

(3) há, presume-se, outras concepções defensíveis de justiça constitucional democrática, cada uma delas talvez corresponda a uma necessidade diferente da sociedade democrática, um conjunto diferente de idéias que são consideradas ponto de partida que levam a uma conclusão diferente sobre o que exatamente uma pessoa racional deveria endossar como sendo uma "concepção política". Sendo assim, então

(4) a falha das democracias constitucionais até aqui para resolver certas questões crônicas sobre o que seja constitucionalmente certou ou errado deve refletir uma pluralidade de concepções políticas, sendo todas passíveis de defesa, caso compitam, de reconstruções de uma visão mais abstrata e compartilhada de sociedade democrática. (MICHELMAN, 2003, p.398)

De acordo com Rawls,

constituição é um processo justo, que satisfaz as exigências da igual liberdade (...) [e] deve ser concebida por forma a que, de todos os sistemas justos e aplicáveis, seja ela a que tem mais possibilidades de conduzir a um sistema de legislação justo e efetivo. (RAWLS, 1993, p.182) 
A formulação de uma constituição justa demanda que se cumpra o princípio da igual participação $^{12}$, o qual exige que todos os cidadãos tenham o mesmo direito de participar do processo constitucional que define as leis que deverão obedecer e é assegurado pela existência de uma forma de constituição democrática, em outras palavras, pela existência de uma autoridade política democrática. Um regime democrático constitucional deve garantir que políticas sociais básicas sejam postas em prática, que haja uma assembléia com poderes legislativos e partidos políticos, além da garantia do direito da participação e da liberdade de expressão, reunião e associação.

Aqui levantamos a questão: por que as liberdades políticas - e somente elas devem possuir valor eqüitativo? John Rawls (2003, p.213) afirma que a idéia de uma garantia de valor eqüitativo para todas as liberdades básicas leva a concepção de igualdade além do que podem abarcar os dois princípios de justiça, além de ser "irracional, supérflua ou ainda fonte de conflitos sociais" (RAWLS, 2003, p.214), pois poderia ser entendida das duas seguintes maneiras:

a) Se essa garantia de valor eqüitativo para todas as liberdades básicas significar que a renda e a riqueza devem ser distribuídas de forma igualitária, ela passa a ser irracional por não permitir que a sociedade respeite as exigências de organização social e eficiência, importantes para seu bom funcionamento. Se essa garantia significar que um certo grau de nível de riqueza deve ser garantido a todos com o objetivo de expressar o

\footnotetext{
${ }^{12}$ Entenda-se o principio da igual participação como sendo o princípio da igual liberdade aplicado ao processo político definido pela constituição (RAWLS, 1993, p.182).
} 
igual valor das liberdades básicas ela é supérflua, pois para este fim existe o principio da diferença.

b) Se essa garantia de valor eqüitativo para todas as liberdades básicas significar que a renda e a riqueza devem ser distribuídas de acordo com certos interesses considerados essenciais para os projetos de vida dos cidadãos, ela, então, causará conflitos sociais.

Assim, a justiça como eqüidade deve eliminar direitos baseados em metas e desejos, que são provenientes das diversas concepções de bem das pessoas e, portanto, incomensuráveis e incomparáveis. Rawls afirma que, desta maneira, certos valores ditos perfeccionistas são eliminados da "família de valores políticos que regem a resolução das questões relativas a elementos constitucionais essenciais e das questões básicas de justiça distributiva" (RAWLS, 2003, p.215). Assim, certas áreas como a matemática, a filosofia ou as artes não deveriam receber recursos públicos volumosos pelo fato de seu estudo e prática possibilitarem o alcance de altos níveis de "excelência de pensamento, imaginação e sentimento" (RAWLS, 2003, p.215): a justificativa para que estas áreas recebam certos montantes dos fundos públicos deve se basear em valores políticos. Ou seja, promover essas áreas com certos montantes dos fundos públicos justifica-se pelo fato de que o desenvolvimento da ciência e da cultura numa sociedade é importante para o aprimoramento de sua cultura política pública, porém, se volumosos montantes forem direcionados para essas áreas, então elas deverão corresponder o investimento com a melhoria das condições dos cidadãos em geral, ou seja, com a melhoria da saúde, com a preservação do meio ambiente, etc. Essa subordinação dos valores perfeccionistas é algo aceitável quando se aplica a questões que dizem respeito aos elementos constitucionais 
básicos e a questões básicas de justiça, uma vez que, em primeiro lugar, deve vir a justiça fundamental (RAWLS, 2003, p. 215).

De acordo com Rawls (2003, p.210), a idéia do valor eqüitativo das liberdades políticas surge com o esforço de responder à objeção freqüentemente feita por democratas radicais socialistas, "de que as liberdades iguais num estado democrático moderno são, na prática, meramente formais", uma vez que as desigualdades sócio-econômicas são tão grandes que fariam com que aqueles que dispõem de mais meios materiais e melhores posições sociais controlassem a vida política, obtendo políticas que correspondam aos seus interesses. Rawls (2003, p.211) diz que, como resposta a esta objeção, a justiça como eqüidade trata as liberdades políticas, e somente elas, de uma maneira especial, incluindo no primeiro princípio uma providência para garantir o valor eqüitativo das liberdades políticas:

(I) Essa garantia significa que o valor das liberdades políticas para todos os cidadãos, seja qual for sua posição econômica ou social, tem de ser suficientemente igual no sentido de que todos tenham uma oportunidade equiitativa de ocupar cargos públicos, de afetar o resultado das eleições e assim por diante. Essa idéia de oportunidade eqüitativa é comparável com a igualdade eqüitativa de oportunidades no segundo princípio.

(II) Quando os princípios da justiça são adotados na posição original, supõe-se que o primeiro princípio inclui essa providência e que as partes levam isso em consideração em seu raciocínio. A exigência de valor eqüitativo das liberdades políticas, bem como o uso de bens primários, faz parte do significado dos dois princípios de justiça.

Rawls destaca duas características da garantia do valor eqüitativo das liberdades políticas:

(a) Primeiro, isso assegura para cada cidadão o acesso eqüitativo e praticamente igual ao uso de recursos públicos concebidos para servir a um propósito político definido, qual seja, o recurso público especificado pelas 
regras e procedimentos constitucionais que governam o processo político e controlam o acesso a posições de autoridade política. Essas regras e procedimentos têm de constituir um processo eqüitativo, elaborado, na medida do possível, para produzir uma legislação justa. As reivindicações válidas de cada cidadão são mantidas dentro de certos limites padrão pela idéia de um acesso eqüitativo e igual ao processo político enquanto recurso público."

(b) Em segundo lugar, esses recursos públicos têm um espaço limitado, por assim dizer. Sem a garantia do valor eqüitativo das liberdades políticas, aqueles que dispõem de mais meios poderiam se juntar e excluir aqueles com menos meios. Presume-se que o princípio de diferença não seja suficiente para prevenir isso. $\mathrm{O}$ espaço limitado do fórum político público permite, digamos, que a utilidade das liberdades políticas esteja muito mais sujeita à posição social e meios econômicos dos cidadãos que a utilidade de outras liberdades básicas. É por isso que acrescentamos a exigência do valor eqüitativo das liberdades políticas. (RAWLS, 2003, p.213)

De acordo com Rawls

“o valor eqüitativo das liberdades políticas garante que cidadãos similarmente dotados e motivados tenham praticamente uma chance igual de influenciar a política governamental e de galgar posições de autoridade independentemente de sua classe social e econômica." (RAWLS, 2003, p.65)

Insere-se, aqui, a questão da manutenção do valor eqüitativo das liberdades políticas. É preciso que não haja restrição ao conteúdo da expressão política, bem como a ausência de ônus excessivo a grupos políticos da sociedade, que devem ser igualmente afetados pelos arranjos institucionais. O veto a grandes contribuições de grupos ou indivíduos a candidatos e partidos políticos não pode ser considerado restrição ao conteúdo da expressão política e nem "ônus excessivo", uma vez que tal contribuição poderia afetar as decisões governamentais, em detrimento daqueles que não detêm elevado poder financeiro para efetuar tais contribuições, minando o princípio do valor eqüitativo das liberdades políticas.

Sendo assim, regulações deste tipo de expressão política devem ser adotadas para que seja garantido o valor eqüitativo das liberdades políticas. As liberdades fundamentais 
configuram uma família de liberdades, e é esta família que deve ser tratada como prioridade, e não uma ou outra liberdade isoladamente. Embora esteja além do âmbito de uma filosofia política detalhar como este problema deva ser resolvido, ela pode, perfeitamente, explicar porque as instituições e normas legais podem ser justificadas. Assim, em $O$ liberalismo político (2000, p.415), Rawls nos permite supor que o financiamento público de partidos políticos e campanhas eleitorais e regulamentações que limitem as contribuições, por exemplo, sejam essenciais para que se mantenha o valor eqüitativo das liberdades políticas. Os arranjos citados são interpretados como "compatíveis com o papel central da expressão política e da imprensa livre, enquanto uma liberdade fundamental" (RAWLS, 2000, p.415), desde que sejam satisfeitas três condições:

1) Desde que não haja restrições ao conteúdo do discurso: sendo assim, os arranjos acima citados são regulações que não favorecem nenhuma doutrina política em detrimento de outras, mas sim regras estabelecidas para que se verifique um procedimento político justo e para que, assim, o valor equiitativo das liberdades políticas seja mantido.

2) Os arranjos instituídos não devem impor ônus excessivo aos vários grupos políticos existentes na sociedade e devem afetar a todos eles da mesma maneira. Aqui o autor frisa, como citado acima, que a proibição de grandes contribuições por parte de pessoas físicas e jurídicas a candidatos políticos não é um ônus excessivo: pelo contrário, esta proibição se faz necessária para que cidadãos igualmente dotados e motivados possam ter uma oportunidade semelhante de influenciar o processo político e galgar postos de autoridade dentro desde sistema, independentemente de seu 
posicionamento socioeconômico. "É precisamente essa igualdade que define o valor eqüitativo das liberdades políticas" (RAWLS, 2000, p. 416). As pequenas doações podem e devem ser vistas como saudáveis do ponto de vista da justiça política, pois trata-se de uma manifestação legítima da expressão política. Deste modo, os candidatos terão um grande número de doadores de pequenos valores, disseminando a importância de cada doador, por todos os doadores. Por outro lado, quando poucos atores doam grandes valores, passam a desequilibrar este sistema, pois um pequeno número de doadores de grandes valores terão o poder de influenciar as políticas e farão valer seus interesses com maior poder, ferindo, sob o ponto de vista da influência, o princípio democrático de "um eleitor, um voto".

3) Todas as regulações da expressão política devem ser definidas tendo em vista o alcance do valor eqüitativo das liberdades políticas, este deve ser seu objetivo definido. Sendo assim, elas devem ser o menos restritivas possível. Uma vez sendo a avaliação do que seria "menos restritiva possível" um tanto quanto complexa, considera-se que, a partir do momento em que medidas menos restritivas capazes de cumprir a mesma função sejam conhecidas e estejam disponíveis, as que estão em vigor deixam de ser razoáveis.

Deste modo, concluímos que se trata, aqui, de ajustar liberdades básicas para que legisladores e partidos políticos possam gozar de independência em relação à grupos detentores de poder econômico elevado, além de garantir que cada cidadão tenha acesso o 
mais eqüitativo possível à influência política e ao uso de recursos públicos, e que estes recursos públicos tenham espaço limitado (RAWLS, 2000, p.415; 2003, p.212). Como temos observado, no que se refere a estes ajustes consta como ponto de destaque o financiamento de partidos políticos e campanhas eleitorais, quer seja através do financiamento público exclusivo, quer seja através do limite às contribuições. Cabe a nós analisarmos qual a melhor configuração do financiamento político para que o valor eqüitativo das liberdades políticas se verifique.

\subsection{A importância da democracia para as liberdades políticas}

Para ilustrarmos de maneira geral a primeira regra de prioridade, segundo a qual o primeiro princípio de justiça sempre deve prevalecer sobre o segundo, e para termos uma noção dos riscos que esta inversão pode trazer, passemos à análise de Desenvolvimento como liberdade (2000), de Amartya Sen.

Neste livro Sen trata da questão da importância da democracia, mesmo para indivíduos que se encontram em situação de extrema vulnerabilidade sócio-econômica, devido ao valor intrínseco, instrumental e construtivo do regime democrático. Sen ilustra o argumento ${ }^{13}$ de que necessidades econômicas muitas vezes pesam mais do que outros fatores como liberdade política e direitos civis com o caso dos coletores de mel em Sunderban, Índia. Nesta região habitam os tigres de bengala, protegidos por lei que proíbe que sejam caçados. Nesta mesma região existem muitas abelhas e,

\footnotetext{
${ }^{13}$ Este argumento vai contra a primeira regra de prioridade, segundo a qual melhorias nas condições socioeconômicas não podem se dar às custas das liberdades civis e políticas protegidas pelo primeiro princípio.
} 
conseqüentemente, uma grande produção de mel, produto que alcança grandes valores no mercado urbano. Sendo assim, os habitantes extremamente pobres da região adentram a floresta em busca de mel para comercializá-lo. Os tigres, como já dissemos, são protegidos por lei, já os habitantes por nada são protegidos, acabando assim, por terem um destino fatal, decorrente do ataque feroz desses animais.

Com isso argumenta-se que se deveria dar prioridade à satisfação das necessidades econômicas mesmo que isso implique um comprometimento das liberdades políticas, e com isso muitos vêm defendendo que focar na questão da democracia e das liberdades políticas é algo como um luxo ao qual os países pobres não podem se dar.

Sen (2000, p.174) nos apresenta a questão freqüentemente repetida nesta linha de análise: "o que deve vir em primeiro - eliminar a pobreza e a miséria ou garantir liberdades políticas e direitos civis, os quais, afinal de contas, têm pouca serventia para os pobres?" Para o autor, esta linha de análise nos oferece uma maneira completamente equivocada de se ver a força das necessidades econômicas ou a importância das liberdades políticas. Na realidade é preciso observar as inter-relações existentes entre liberdades políticas e a compreensão e satisfação de necessidades econômicas, interrelações estas que não são apenas instrumentais, mas também construtivas. Para que se possa realmente definir quais são as necessidades econômicas, para que possa haver um processo de geração de escolhas (e crenças) bem fundamentadas e refletidas, é preciso que existam debates públicos abertos, livres e esclarecedores e, para isso, faz-se necessária a garantia da liberdade política e dos direitos civis básicos. Na realidade, de acordo com Sen, a intensidade das necessidades econômicas aumenta, e não reduz a urgência das liberdades políticas. 
Sen (2000, p.175) nos apresenta algumas análises contrárias à democracia e aos direitos civis que partem de três direções distintas:

a) Afirmam que as liberdades e direitos políticos tolhem o crescimento econômico. Amartya Sen contraria esta vertente afirmando que não existem dados efetivos e definitivos que nos provem que o autoritarismo esteja relacionado com um maior crescimento econômico, o mesmo servindo para a democracia. Da mesma maneira, não há provas de que haja qualquer tipo de conflito entre liberdade política e desenvolvimento econômico, além, claro, do fato de liberdades políticas e liberdade substantiva possuírem importância própria. Ao avaliarmos o desenvolvimento econômico devemos, além das estatísticas, avaliar processos causais, tais quais "políticas úteis" para que este processo se verificasse, sendo que não há nada que indique que tais políticas sejam incompatíveis com o regime democrático. Os direitos políticos e civis dão aos cidadãos a oportunidade de chamar a atenção para os problemas enfrentados de maneira eficaz e exigir a ação pública apropriada, e a ação, ou seja, a resposta do governo a esta exigência, depende da pressão sobre ele exercida e é nisso que o exercício dos direitos políticos possui papel fundamental ${ }^{14}$.

b) Afirmam que se aos pobres for dado escolher entre liberdades politicas e satisfazer suas necessidades econômicas, a segunda alternativa será a escolhida. Esta afirmação baseia-se em poucas evidências empíricas, uma vez que não está nada claro de que maneira esta afirmação poderia ser avaliada nas situações em que os cidadãos não possuem liberdade para manifestarem suas opiniões a respeito do tema ou para contestarem a opinião dos detentores de poder. De fato, vários líderes de

\footnotetext{
${ }^{14}$ Esta é parte do papel "instrumental” da democracia e das liberdades políticas.
} 
países de terceiro mundo depreciam os direitos e liberdades políticas, porém, não podemos estender esta opinião à população, o que podemos comprovar, por exemplo, com a existência de vários movimentos em países de terceiro mundo em prol das liberdades políticas.

c) Afirmam que a ênfase sobre as liberdades políticas, formais e sobre a democracia é um valor especificamente ocidental, não se encaixando na cultura asiática, mais voltada para a ordem e a disciplina. Recentemente tem-se invocado a idéia de valores asiáticos para justificar governos autoritários na região, porém, isto provem não de historiadores, mas de autoridades. No entanto, a extensão do território asiático, a quantidade de habitantes que se encontram na região e a diversidade dificultam que tais generalizações sejam feitas e, quando o são, são extremamente grosseiras.

Deste modo, Sen nos mostra que o exercício dos direitos básicos torna mais provável que as necessidades econômicas encontrem uma resposta satisfatória por parte dos governantes, além do que, para que tais necessidades sejam efetivamente levadas em consideração pelos tomadores de decisões é preciso que haja muita discussão e diálogo, o que é possível apenas quando as liberdades políticas são devidamente respeitadas.

Vale ressaltar que

a democracia não serve como um remédio automático para doenças do mesmo modo que o quinino atua na cura da malária. A oportunidade que ela oferece tem de ser aproveitada positivamente para que se obtenha o efeito desejado. (SEN, 2000, p.182) 
Em sendo assim, o regime democrático abarca uma série de oportunidades, porém, a maneira como elas serão aproveitadas e o grau de seu aproveitamento dependem diretamente dos indivíduos envolvidos no processo, uma vez que as realizações do regime dependem não apenas das regras do jogo e procedimentos adotados e preservados, como também de como as oportunidades são aproveitadas pelos cidadãos. Observemos abaixo a explicação dada por Fidel Valdez Ramos, expresidente das Filipinas, em novembro de 1988 na Australian National University, para esta questão:

Sob um regime ditatorial, as pessoas não precisam pensar - não precisam escolher - não precisam tomar decisões ou dar consentimento. Tudo o que precisam fazer é obedecer. Essa foi uma lição amarga aprendida com a experiência política filipina não muito tempo atrás. Em contraste, a democracia não pode sobreviver sem virtude cívica. [...] O desafio político para os povos de todo o mundo atualmente não é apenas substituir regimes autoritários por democráticos. É, além disso, fazer a democracia funcionar para as pessoas comuns. (SEN, 2000, p.183)

Deste modo, a maneira e a intensidade com que as oportunidades oferecidas pelo regime democrático serão aproveitadas dependem de vários fatores encontrados dentro das sociedades como, por exemplo, o vigor da política multipartidária, o dinamismo dos argumentos morais e da formação de valores (relembrando a importância da discussão e do debate livre, propiciados pela liberdade política para que esta característica se verifique) e a atuação dos partidos de oposição - algo de extrema importância, tanto em regimes democráticos quanto nos não-democráticos.

Com isso Sen conclui afirmando que desenvolver e fortalecer o sistema democrático é um fator crucial no processo de desenvolvimento de uma sociedade. Apesar de 
apresentarem limitações, tanto as liberdades políticas quanto os direitos civis têm sido usados de maneira eficaz com bastante freqüência e sua comprovada eficiência na prevenção de desastres econômicos tem sido freqüientemente verificada. Quando a saúde política e econômica de uma nação vai bem a ausência deste papel da democracia não é tão fortemente sentida, porém, quando as coisas não correm tão bem, ela é fortemente desejada, quando "os incentivos políticos fornecidos pelo governo democrático adquirem grande valor prático" (SEN, 2000, p.186).

Assim como é importante salientar a necessidade da democracia, também é crucial salvaguardar as condições e circunstâncias que garantem a amplitude e o alcance do processo democrático. Por mais valiosa que a democracia seja como uma fonte fundamental de oportunidade social (reconhecimento que pode requerer uma defesa vigorosa), existe a necessidade de examinar os caminhos e os meios para fazê-la funcionar bem, para realizar seus potenciais. A realização da justiça social depende não só de formas institucionais (incluindo regras e regulamentações democráticas), mas também da prática efetiva. Assim, Sen nos apresenta razões para que consideremos a questão da prática fundamentalmente importante nas contribuições que podemos esperar dos direitos civis e das liberdades políticas, sendo este um desafio encontrado tanto em democracias bem estabelecidas quanto em democracias recentes (SEN, 2000, p.187). 


\subsection{Participação política, democracia e distribuição}

A participação política possui valor reconhecido dentro da teoria democrática e da teoria da justiça, sendo ela uma das liberdades políticas abarcadas pelo primeiro princípio de justiça. Através da participação os cidadãos podem debater, trocar informações e formar opiniões acerca do processo político. No que se refere ao exercício da participação política numa democracia representativa, papel importante ocupam os partidos políticos. Apesar de o personalismo ser uma característica do atual estágio em que se encontra a representação política (MANIN, 1997), sem os partidos políticos este personalismo ganharia uma força extrema, além do desejável para o bom funcionamento da democracia, causando um afastamento dos princípios do governo representativo (URBINATI, 2006a, p.219). De acordo com Michael Walzer, "a política partidária, pelo contrário, não é uma batalha, mas uma luta longa (...), requer compromisso e perseverança (...) A política partidária é assunto de reuniões e discussões" (WALZER, 2003, p.422). Assim, os partidos políticos ${ }^{15}$, além de contribuírem para a "política do coletivo", também favorecem a existência de debate político, ou seja, da deliberação. Além disso, os partidos políticos prestam um serviço público essencial:

o de selecionar, recrutar e capacitar candidatos para que exerçam cargos públicos, mobilizar os eleitores, participar e depois ganhar ou perder as eleições, assim como formar governos. Em um modelo ideal, os partidos agregam interesses, desenvolvem alternativas de política e, em geral, constituem o principal elo entre a cidadania e o governo. (ZOVATTO, 2005, p.288)

\footnotetext{
${ }^{15}$ Aqui encontramos uma afirmação que serve de respaldo para a visão de que os partidos possuem papel de extrema importância nas democracias representativas, justificando, inclusive, a necessidade de subsídio público para a manutenção e fortalecimento dos mesmos (ZOVATTO, 2005, p.299).
} 
Dentre os papéis dos partidos políticos devemos destacar o de promover o que Michael Walzer chama de auto-respeito dos cidadãos, idéia que podemos remeter ao domínio das duas faculdades morais, encontradas em John Rawls. De acordo com Álvaro de Vita (1999, p.39), “a realização dos dois princípios de justiça pela estrutura básica da sociedade cria as 'bases sociais' do auto-respeito, que Rawls entende ser o bem primário mais importante". De acordo com Vita, a prioridade das liberdades fundamentais tem o papel de promover, na estrutura básica da sociedade, o respeito dos cidadãos pelas formas de vida e concepções de bem uns dos outros, desde que estas formas de vida não comprometam os princípios de justiça.

Cohen (2003) aponta o auto-respeito como sendo um bem fundamental por ser précondição para a perseguição de nossos objetivos de vida, bem como por sua base social - o respeito pelos outros - ser, também, um bem crucial. Em outras palavras, sentir-se respeitado dentro da sociedade em que se está inserido e respeitar os demais indivíduos pertencentes a esta sociedade, enquanto indivíduos livres e iguais, possuidores das duas faculdades morais, torna-se algo vital para que uma sociedade democrática se verifique. $\mathrm{O}$ cidadão se respeita por acreditar ser capaz de entrar na luta política quando desejar e pela possibilidade de resistir à transgressão de seus direitos. É importante que o cidadão sinta-se capaz de deliberar perante seus companheiros, de ouvir e ser ouvido (WALZER, 2003, p.426). A luta em si possui valor imprescindível para a saúde da democracia e da igualdade política, uma vez que ela própria é a negação da impotência e é uma das formas mais genuínas da prática da virtude cidadã. “Os partidos políticos e os movimentos que organizam a luta são o berço dos cidadãos que têm auto-respeito" (WALZER, 2003, p.426), daí podemos concluir a extrema importância de se restaurar a confiança nos partidos políticos, tão abalada em grande parte das democracias contemporâneas, além da 
importância de se financiar a sua manutenção e a possibilidade de concorrência entre eles. É claro que não há uma garantia de que, uma vez estabelecido este meio de manifestação, os cidadãos irão empregá-lo e envolver-se-ão na luta política, mas este canal deve ser garantido, tendo em vista que, quando destituído da sensação de capacidade de deliberar perante seus companheiros, o cidadão encontra-se destituído da noção de si mesmo. Walzer (2003, p.426) diz que, de acordo com alguns escritores do século XX, "o poder corrompe, mas a falta de poder corrompe completamente". Isso se verifica não em outra situação, a não ser numa democracia em que a noção de poder em potencial é reconhecida como uma forma de saúde moral. "Os cidadãos que não têm auto-respeito sonham com uma vingança tirânica" (WALZER, 2003, p.426). Este problema é mais preocupante quando os partidos políticos não estão plenamente fortalecidos, cumprindo seu papel. $O$ grande descontentamento que vem surgindo nos últimos anos em todas as democracias (tanto nas mais consolidadas quanto nas emergentes) em relação aos partidos políticos se dá, sobretudo, devido à questão da intromissão excessiva do dinheiro na política, abrindo caminho para a desigualdade e a corrupção. O problema do domínio do dinheiro na esfera política é, sem dúvidas, uma das maiores ameaças existentes ao auto-respeito. Quando a política se vê manipulada por aqueles que detêm poder econômico, aqueles que não dispõem de tal poder sentem-se desesperançados e totalmente excluídos do processo político. Os cidadãos destituídos de posses têm a profunda convicção de que a política não lhes oferece esperança alguma, gerando um sentimento de passividade e ressentimento (daí o sonho da vingança tirânica). Em sendo assim, para quê empregariam estes indivíduos seu tempo, bem precioso, na participação política? Todos sabemos dos custos para se participar do processo político, sendo um deles o tempo empregado na obtenção de informação sobre o assunto. Vale a pena este esforço se, no fim das contas, o que influencia a política é o 
poder econômico, em outras palavras, quem influencia a política são aqueles que detêm posses? Walzer nos diz que este processo deve ser evitado: deve ser evitado que esta sensação de impotência evolua para uma perda do auto-respeito num círculo estreito, uma vez que a luta contra a influência do dinheiro na política e contra o poder do empresariado "talvez seja a mais requintada expressão contemporânea de auto-respeito" (WALZER, 2003, p.426). Deste modo a necessidade de fortalecimento dos partidos políticos, como instituição organizadora do processo democrático representativo, faz-se primordial para que o problema da influência nociva do dinheiro na esfera política- motivo principal para que o financiamento de partidos políticos e campanhas eleitorais tenha se inserido na agenda política de diversos países (ZOVATTO, 2005) - possa ser enfrentado de maneira eficaz.

É importante ressaltar, no entanto, outro ponto preponderante para que a participação e o auto-respeito encontrem-se ameaçados: de acordo com Vita,

\begin{abstract}
"os níveis desiguais de participação política se devem, em larga medida, à distribuição desigual de recursos políticos cruciais, tais como renda, riqueza, tempo disponível para a atividade política, capacidade de organização (ou maior facilidade para superar problemas de ação coletiva), informação e interesses políticos, intensidade de preferências com respeito a questões públicas e nível educacional.” (VITA, 2000, p.10)
\end{abstract}

Concluímos, assim, que participar não é somente uma questão de escolha individual, mas sim uma questão de expansão de oportunidades, tanto sob o ponto de vista político quanto social. A redistribuição de renda e o ambiente propício ao desenvolvimento de uma cultura política favorável à participação política é, sem dúvida alguma, uma das maiores preocupações referentes à democracia moderna.

No que se refere á problemática da distribuição de recursos dentro da sociedade, Rawls (1993) observa que, através da combinação entre o princípio da igualdade eqüitativa 
de oportunidades e o princípio da diferença, podemos chegar a igualdade democrática. De acordo com o princípio da diferença,

as expectativas mais elevadas dos sujeitos que estão melhor situados são justas se, e apenas se, funcionarem como parte de um sistema que melhore as expectativas dos membros menos beneficiados da sociedade. (RAWLS, 1993, p.78)

No entanto, a diferença entre aqueles que estão em posição mais favorecida e aqueles que estão em posição mais desfavorecida não deve ser exagerada, pois, deste modo, o princípio de vantagens mútuas e o princípio da igualdade democrática ${ }^{16}$ estarão sendo violados. Por outro lado, parece provável que, ao melhorar a situação dos menos favorecidos, a situação dos cidadãos em geral melhorará também, numa freqüente difusão de benefícios (RAWLS, 1993).

"O princípio de igualdade democrática requer que os mais privilegiados abram mão de tirar proveito de certas circunstâncias sociais e naturais que os beneficiam, a não ser quando fazê-lo beneficia também os que têm o menor quinhão de bens primários." (VITA, 1999, p.48)

A solução proposta por Rawls para enfrentar a arbitrariedade moral da ótica da concepção democrática é exatamente o princípio da diferença, para o qual nenhum tipo de distribuição desigual de bens primários pode se justificada. O princípio da diferença oferece "a única interpretação possível pra um igualitarismo não invejoso", trazendo reforço ao

\footnotetext{
${ }^{16}$ De acordo com Vita (1999, p.47), as desigualdades podem ocorrer dentro de uma sociedade devido a fatores sociais e familiares Na prática ambos são indissociáveis e igualmente arbitrários do ponto de vista moral. A igualdade democrática enfrenta a arbitrariedade moral tratando da questão de "alterar o fundamento moral a partir do qual é legítimo reivindicar os benefícios produzidos pelo exercício dos talentos" (VITA, 1999, p.47), em outras palavras, não é porque possuo um talento incomum especialmente valorizado pelos arranjos sociais que irei exigir uma renda exageradamente maior do que a de um trabalhador comum. Posso, deste modo, inclinar-me a compartilhar com os demais os pontos positivos e negativos da distribuição de talentos. Fica, assim, evidente o forte componente moral desta idéia, em detrimento da identidade pessoal.
} 
auto-respeito dos cidadãos (VITA, 1999, pp. 48-49), haja vista a importância do autorespeito para a manutenção do valor eqüitativo das liberdades políticas.

Porém, quando observamos os regimes democráticos constitucionais existentes, verificamos que o problema da desigualdade é real e intenso. Verificamos, ainda, que um dos maiores defeitos dos regimes constitucionais tem sido exatamente a sua incapacidade de assegurar o justo valor da liberdade política, o que se deu pelo fato de o sistema jurídico ter tolerado grandes disparidades na distribuição da riqueza e da propriedade gerando, assim, uma situação bastante distante da ideal e pelo fato de recursos públicos não terem sido empregados na manutenção das instituições exigidas pelo justo valor das liberdades políticas. O poder político concentra-se rapidamente, permitindo que o aparelho coercitivo do Estado e as leis sejam utilizados sem a neutralidade ideal, fazendo com que as desigualdades sociais e econômicas possam minar a igualdade política (RAWLS, 1993, p.185).

Pensemos, agora, na questão da (pouca) capacidade do sistema político democrático de redistribuir riqueza. Aqui entramos em um dos pontos trabalhados por Ian Shapiro em seu The State of Democratic Theory que é o da relação existente entre democracia e redistribuição. A questão central seria "se, e em que condições, a democracia redistribui [riqueza] para o quintil inferior da população ${ }^{17 ”}$ (SHAPIRO, 1996, p.104). Na realidade, não há relação demonstrada entre expansão da democracia e redistribuição de riqueza para os menos afortunados. Apesar de as democracias gastarem mais dinheiro do que as não democracias com a erradicação da pobreza, este gasto não possui impacto sistemático na desigualdade, permanecendo significativas porções da população na pobreza. Deste modo,

\footnotetext{
${ }^{17}$ De acordo com Shapiro, os interesses básicos desta parcela da população encontram-se em perigo e, como conseqüência, eles se tornam vulneráveis à dominação, algo altamente indesejável numa democracia.
} 
torna-se de fundamental importância atentar para quais pontos podem e devem ser alterados pela reforma política para que este quadro possa, de fato, ser modificado.

Para compreender melhor a natureza da relação entre democracia e redistribuição, Shapiro trata do que denomina "oferta de políticas de natureza redistributiva" (supply side $)^{18}$, e questiona "por que os políticos e as elites políticas não tentam trazer mais políticas redistributivas para o debate?" (SHAPIRO, 1996, p.105). “O que impede os políticos de competirem pelos votos dos menos afortunados através da oferta de políticas que redistribuiriam para eles a renda dos grupos mais ricos?” (SHAPIRO, 1996, p.106). Dentre os motivos, o autor aponta os obstáculos à taxação, que podem ser conseqüência da influência dos grupos que contribuem para o financiamento das campanhas e influenciam as plataformas dos partidos, o temor dos políticos da fuga de capital (capital flight), instituições como as cortes, que possuem poder de veto e vários limites estruturais e institucionais para o aumento do rendimento público (revenue). Outras explicações para o fenômeno se baseiam no tratamento dado aos gastos, enfatizando o poder de outros grupos de interesse, que não os mais pobres, nos gastos governamentais. Devido às dificuldades estruturais e contextuais de se elevar os rendimentos públicos o caminho escolhido acaba sendo o de controlar gastos, sofrendo com isso, as políticas de natureza redistributiva.

Devido ao papel de destaque atribuído aos grupo de interesse neste processo, Shapiro (1996, p.108) identifica na questão do financiamento de campanhas um ponto muito importante do mecanismo da oferta de políticas de natureza redistributiva. O autor afirma que os políticos necessitam de grandes somas de dinheiro para serem candidatos

\footnotetext{
${ }^{18}$ Shapiro trata, também, do que ele denomina demand side, mas não tratarei deste ponto nesta dissertação.
} 
viáveis, em grande parte devido aos valores gastos com a propaganda política ${ }^{19}$. Este tema é de difícil análise devido à incerteza dos dados oficiais disponíveis: existem vários meios, que não aparecem nestes dados, através dos quais as contribuições podem ser feitas. Assim, têm sido propostas várias reformas para o financiamento de campanhas, apesar de não estar claro se alguma delas faria diferença para a situação do quintil inferior da população. Dentre as reformas mais desejáveis, encontram-se a determinação de limitar contribuições para mais de um candidato na mesma eleição ou membros do mesmo partido no comitê legislativo e o estabelecimento da doação secreta ${ }^{20}$.

Como podemos ver, a questão de como manter a esfera política livre da influência do poder econômico, a importância da participação, da distribuição de renda, da manutenção do valor eqüitativo das liberdades políticas e, mais ainda, a preocupação com a questão do financiamento de partidos políticos e campanhas eleitorais tem sido um dos pontos levados em conta pelos teóricos da justiça e da democracia. Sobre este assunto, Rawls sustenta que nossa concepção de cidadania democrática igual nos compromete com o objetivo de erguer barreiras entre o poder econômico e o poder político. Quais arranjos institucionais poderiam ser eficazes para realizar esse objetivo, é algo que requer mais

\footnotetext{
${ }^{19}$ Aqui faço referência às observações encontradas na bibliografia sobre financiamento de campanhas eleitorais.

${ }^{20}$ Este mecanismo esconderia a identidade do doador. Assim, o beneficiado jamais saberia quem teria doado e com que valor. Um dos defensores desta forma de financiamento político é Yan Ayres da Yale Law School.

Em seu artigo "Should campaign donors be identified?" Ayres defende a teoria de que a doação anônima seria mais efetiva do que a doação secreta no combate à corrupção, pois dificultaria que os políticos pudessem recompensar os doadores, reduziria substancialmente o número de grandes doações (doadores de grandes somas esperam benefícios concretos) e aumentaria o número de pequenas doações. Para Ayres há consenso de que a lei deve forçar os candidatos a revelarem os doadores, porém, para ele, esse mecanismo não é o mais eficaz porque quando acusados de tomarem alguma decisão que favoreça aos doadores, os políticos podem alegar que agiriam desta mesma maneira independentemente da doação, uma vez que não há proibição legal contra a venda de acesso, que é um tipo de corrupção que pode ser provado, ao passo que a compra de influência, que seria um tipo de corrupção ilegal, não pode ser comprovado. O autor traça uma comparação entre a doação secreta/anônima e o voto secreto, alegando que a doação secreta daria muito mais liberdade aos políticos. Além disso, a doação anônima daria maior liberdade ao doador, que não seria obrigado a dizer o quanto doou e, mesmo que desejasse, não disporia de mecanismos que permitissem provar que contribuiu com determinada quantia.
} 
investigação teórica e empírica (VITA, 2003, p.125). Em Justiça como Eqüidade, Rawls (2003, p.212) aponta a análise da melhor maneira de se realizar o valor eqüitativo das instituições políticas como sendo uma importante diretriz de pesquisa. Por fim, Rawls afirma:

"Não tenho como analisar aqui qual a melhor maneira de realizar esse valor eqüitativo nas instituições políticas. Apenas parto do princípio de que existem modos institucionais viáveis de tornar isso compatível com o âmbito central de aplicação das outras liberdades básicas.” (RAWLS, 2003, p.212)

Esta dissertação pretende analisar as configurações que o financiamento político pode assumir, tendo em vista qual o melhor arranjo para a realização do valor eqüitativo das liberdades políticas. 


\section{Capítulo 2: Representação e teoria democrática}

As democracias modernas têm passado por algumas mudanças, no último quartel do século XX, que resultaram num novo tipo de representação política. Neste novo tipo de representação, os partidos políticos perderam seu papel central como centralizadores de identidades e preferências; as alterações socioeconômicas tornaram as clivagens sociais, econômicas e culturais mais fluidas, dificultando uma identidade baseada nestas referências; a figura do representante é cada vez mais forte, reforçando laços personalistas e a mídia tem assumido papel cada vez mais importante na relação entre representado e representante. A conjunção de todos estes fatores tem sido interpretada no meio acadêmico e político como uma crise da representação política (LAVALLE et al, 2006; MANIN, 1997; URBINATI, 2006).

É este quadro que serve de pano de fundo para nossa análise a respeito do financiamento político, é neste contexto que o financiamento político por nós discutido se desenvolve. Financiamento político e representação política estão intimamente atrelados e, nas democracias contemporâneas, um não sobrevive sem o outro. A representação é o componente central do governo representativo e, nas sociedades atuais, com um número cada vez maior de eleitores - graças ao sufrágio universal -, a comunicação entre eleitorado e representante tem sido muito importante e especialmente cara, sendo o financiamento político algo imprescindível para a saúde dos governos democráticos, sobretudo em países de dimensões continentais, como é o caso do Brasil. 
Sendo assim, neste capítulo procurarei analisar se a maneira através da qual a representação política se apresenta atualmente realmente se configura numa crise da representação. Para tanto, analisarei o trabalho de Bernard Manin, The principles of representative government, de 1997. A análise passará pela questão da superioridade do governo representativo frente à democracia direta e pelas transformações pelas quais o governo representativo tem passado desde sua origem, no século XVII, até sua configuração atual, sobretudo no que se refere aos fatores que Manin considera terem se mantido estáveis desde a origem do governo representativo, fatores, estes, que se encontram intimamente ligados às liberdades políticas e possuem extrema importância no processo de manutenção do valor eqüitativo das liberdades políticas.

Com isso espero verificar se, para que o valor eqüitativo das liberdades políticas se verifique, é preciso repensar um novo sistema de governo ou se o governo democrático representativo é adequado, bastando repensar mecanismos internos a esta forma de governo que sejam capazes de assegurar - ou ao menos ampliar o alcance - do valor eqüitativo das liberdades políticas.

2.1. Reflexões acerca da Representação Política e da Democracia Representativahá uma crise da representação?

Grande defensor da democracia direta, Jean-Jacques Rousseau (1973, p.90) afirmou em sua obra Do contrato social que "jamais existiu, jamais existirá uma democracia verdadeira", devido às dificuldades práticas para sua implementação e manutenção. De acordo com o autor, para que se verificasse uma democracia autêntica seria necessário: 
Em primeiro lugar, um Estado muito pequeno, no qual seja fácil reunir o povo e onde cada cidadão possa sem esforço conhecer todos os demais; segundo uma grande simplicidade de costumes que evite a acumulação de questões e as discussões espinhosas; depois, bastante igualdade entre as classes e as fortunas, sem o que a igualdade não poderia subsistir por muito tempo nos direitos e na autoridade; por fim, pouco ou nada de luxo - pois o luxo ou é o efeito de riquezas ou as torna necessárias; corrompe ao mesmo tempo o rico e o pobre, um pela posse, o outro pela cobiça; entrega a pátria à frouxidão e à vaidade; subtrai do Estado todos os cidadãos para subjugá-los uns aos outros, e todos à opinião. (ROUSSEAU, 1973, p.91) [Grifo meu]

Rousseau conclui sua tese afirmando que "se existisse um povo de deuses, governarse-ia democraticamente. Governo tão perfeito não convém aos homens" (ROUSSEAU, 1973, p.92). Vale ressaltar que Rousseau desprezava as formas de democracia empiricamente observadas, quer fosse a democracia representativa ou a direta, pelo fato de ambas basearem-se no discurso, o que fazia com que fosse necessária a competição para se chegar ao consenso e neste processo, a retórica e o juízo de valores fazer-se-ia essencial, e não a vontade geral. Para ele, a democracia de fato ficaria no plano das idéias (URBINATI, 2006b). Rousseau teria passado de uma radical negação da representação para a defesa da delegação ao longo de seus trabalhos. De acordo com alguns críticos, essa suposta negação na teoria e aceitação na prática seria uma contradição democrática. No entanto, Urbinati (2006b) não vê esse posicionamento de Rousseau como algo contraditório, pois Rousseau aceitava a delegação porque, para ele, esta era diferente da representação.

Seguindo as idéias de Rousseau, baseados na premissa da necessidade de um Estado pequeno para que a democracia direta possa se efetivar, vários defensores da democracia 
direta atribuem à democracia representativa ${ }^{21}$ o posto de segunda opção, imposta pela força das circunstâncias em que se encontram as sociedades modernas. Para esta corrente o ideal seria a democracia direta ${ }^{22}$ mas, como as sociedades estão cada vez mais complexas e numerosas, e com a multiplicação de opiniões e de fortunas, sua implementação torna-se impossível, nos restando aceitar, com insatisfação, a democracia representativa.

De outro lado, existem autores que defendem a democracia representativa e a definem não como uma segunda opção, mas sim como uma opção melhor do que a democracia direta. Nadia Urbinati (2006a,b) defende esta posição exaltando a representação ao afirmar que "a instituição da representação é considerada a fonte da 'distinção moral' da democracia moderna e é até mesmo o sinal da superioridade desta em relação à democracia direta" (2006b, p.4). Urbinati alega que a representação política é um processo circular entre instituições estatais e práticas sociais, permitindo que a democracia se recrie e aprimore-se constantemente. Para a autora, a democracia representativa possibilita a criação de vínculos e a continuidade (longue durèe) de idéias e políticas, algo impossível na democracia direta, onde os votos se resumem a um assunto delimitado no tempo e no espaço, sem que se constituam laços capazes de perdurarem para além desta delimitação: "cada voto é como um novo começo" (URBINATI, 2006a, p.212). Por este motivo a política representativa surge como um fator de estabilidade para a sociedade. Novaro diz que

"reconhecer que a representação constitui e redefine permanentemente as identidades, vontades e interesses é uma condição necessária para pensar em

21 De acordo com Bobbio (2000, p.56), “democracia representativa significa, genericamente, que as deliberações coletivas, isto é, as deliberações que dizem respeito à coletividade inteira, são tonm, madas não diretamente por aqueles que dela fazem parte, mas por pessoas eleitas para esta finalidade".

${ }^{22}$ Não tratarei, nesta dissertação, da democracia direta. 
uma ampliação radical da política democrática, pois permite abandonar o essencialismo de identidades fixas dadas, de que se alimentam em boa medida as tradições autoritárias e as visões restritivas da democracia." (2000, p.74)

Norberto Bobbio (2000) vai por um caminho semelhante ao afirmar que, hoje, o que devemos buscar é uma ampliação da democracia, da democracia política para a democracia social. Com a ampliação do sufrágio universal a questão a ser feita quando desejamos saber quão democrática é uma nação não é mais quem vota, mas sim onde se vota. A questão não é ampliar a democracia representativa fazendo com que ela seja substituída pela democracia direta. Bobbio diz que a democracia direta e a representativa podem conviver - porém a democracia direta à qual ele se refere não é aquela que implica "literalmente a participação de todos os cidadãos em todas as decisões a eles pertinentes" (BOBBIO, 2000, p.54), pois seria uma insensatez defendê-la nos dias atuais, nas sociedades atuais. Trata-se da ampliação da democracia em sentido ascendente, isto é, trata-se do poder político exercido em todos os níveis (local, estatal e regional), em nome do indivíduo como cidadão, da esfera política para a esfera social (BOBBIO, 2000, p.66$67)$.

Como nos mostra Bernard Manin em seu The principles of representative government (1997), a idéia de superioridade da representação já encontrava espaço nos pensamentos de dois nomes que foram centrais na concepção do governo representativo: Madison e Siéyès. Para Madison, a representação é superior pelo fato de as decisões passarem por pessoas eleitas para tanto, pessoas cuja capacidade de discernimento seria superior à da maioria da nação, sendo livre de paixões e parcialidades. Atualmente, quando pensamos no que distingue a democracia direta da representativa, frequientemente concluímos que seja o fato de todos os poderes políticos importantes serem exercidos pela assembléia do povo, mas 
esta é uma idéia equivocada. De acordo com Madison, nas "democracias diretas" do mundo antigo (Atenas, em particular) a assembléia popular não era o berço de todo o poder: muitos poderes importantes não estavam nas mãos de pessoas da assembléia, mas sim nas mãos de magistrados eleitos e cidadãos selecionados via sorteio (lot). É importante ressaltar que nenhum governo representativo, nos últimos dois séculos, sequer cogitou o sorteio como forma de seleção de representantes: a representação tem sido associada apenas a eleições, por vezes associadas a fatores como hereditariedade - como nas monarquias constitucionais - mas jamais com o sorteio. A questão que se faz aqui é: porque o sorteio tem sido rejeitado pelos governos representativos como forma de seleção?

O motivo, como alguns poderiam alegar, não é o tamanho cada vez maior dos Estados-nação, uma vez que cidades e até países dos séculos XVII e XVIII não diferiam muito, em termos populacionais, das antigas cidades que adotavam o sorteio como método de seleção de representantes. Também não podemos alegar que o sistema de sorteio coloque no poder aqueles que não querem exercê-lo, porque o sorteio ocorria apenas dentre aqueles que demonstravam interesse em ocupar algum cargo público e, além disso, estes indivíduos passavam por exames que visavam a avaliar se estavam realmente aptos a ocupar o cargo: se sua conduta em relação aos seus familiares era satisfatória, se estavam em dia com o pagamento de impostos e se haviam prestado o serviço militar. Outro ponto de questionamento pode residir na ausência de fiscalização dos representantes neste método de seleção. Este questionamento, porém não se sustenta porque esses magistrados eram constantemente monitorados pela Assembléia e pelas cortes. Isso nos mostra que o sorteio era uma forma de seleção que exigia o cumprimento de pré-requisitos e garantia a vigilância por parte de outros órgãos, e o fator voluntariado associado aos "riscos" 
(responsabilidades adquiridas e fiscalizadas) de assumir o cargo já eram responsáveis, por si só, por uma certa pré-seleção dentre os aspirantes a candidatos.

É importante ressaltar, porém, que os cargos considerados estratégicos - como o de generais, altos administradores militares, e chefes financeiros - não eram preenchidos através de sorteio, mas sim através de eleições ${ }^{23}$. De qualquer maneira, o poder de fazer propostas e tomar a iniciativa nas assembléias não eram oficialmente exclusivos de magistrados e políticos, mas sim um direito estendido a todos os cidadãos. Mas então, o que este sistema empregado em Atenas, que contava com representantes, teria de democracia direta? No caso, seria a forma de seleção dos representantes: o sorteio. Se por um lado alguns historiadores acreditavam que a origem do sorteio em Atenas era religioso e ser sorteado, neste caso, seria um chamado divino -, incontáveis fontes definem o sorteio como sendo uma característica típica da democracia: o sorteio seria o método de seleção democrático por excelência e a eleição seria um método de seleção associado à oligarquia ou à aristocracia. Aristóteles acreditava que o sorteio era democrático e as eleições, oligárquicas; que depender de qualificações de propriedade para ser selecionado como representante era oligárquico, e não depender, democrático. No entanto, Aristóteles defendia a idéia de que, combinando de determinadas maneiras características democráticas e oligárquicas de governo, seria possível alcançar uma constituição mista que, por sua vez, seria melhor do as formas separadas. Deste modo, várias combinações de sorteio, eleição e qualificações de propriedade poderiam resultar neste tipo de constituição mista ao qual ele se refere em Política. Para ele as eleições - apesar de isoladamente serem consideradas

\footnotetext{
${ }^{23}$ No século V generais e políticos de influência pertenciam a famílias tradicionais (old families), no século IV os líderes políticos passaram a ser selecionados dentre famílias de posses, e através de toda a história da democracia ateniense sempre houve certa correlação entre o pertencimento às elites políticas e sociais e o exercício de cargos políticos (MANIN, 1997, p.15).
} 
oligárquicas ou aristocráticas, enquanto o sorteio era visto como essencialmente democrático - poderiam estar presentes numa forma democrática de governo (MANIN, 1997, pp. 27-28).

Para entendermos a ligação existente entre democracia e sorteio para os atenienses, devemos compreender que a idéia central de democracia para eles residia na idéia de rotatividade e na possibilidade de os indivíduos ocuparem duas posições alternativamente: a de comandar e a de obedecer. Para eles, para que uma pessoa pudesse ser capaz de governar de maneira satisfatória deveria, também, ser capaz de obedecer de maneira satisfatória, e vice-versa; aquele que hoje dá as ordens deve ter a consciência de que amanhã estará na posição dos governados. Neste ponto podemos questionar: mas as eleições também não possuem este caráter rotativo? De acordo com Manin (1997), não: ao contrário do sorteio, que implica uma seleção mais aleatória, onde todos gozam de probabilidades semelhantes de serem escolhidos, a eleição determina que os cidadãos sejam livres para escolherem quem eles querem que governe e quantas vezes querem que esta pessoa governe, ou seja, os cidadãos podem desejar que uma mesma pessoa seja reeleita ano após ano. Para evitar isso seria preciso limitar a liberdade de escolha dos cidadãos, determinando que uma pessoa já eleita não possa vir a ser eleita novamente.

Além disso, os atenienses nutriam profunda desconfiança em relação à profissionalização da política: com exceção de certos casos em que determinadas habilidades profissionais eram reconhecidas como necessárias, os atenienses não aprovavam a idéia de profissionais intervirem na política porque, inevitavelmente, eles acabariam dominando o cenário político, em detrimento dos cidadãos comuns e a seleção via sorteio deveria garantir que os magistrados não fossem selecionados devido a determinadas habilidades (como ocorre nas eleições) (MANIN, 1997, pp.32-33). Aqui 
encontramos um importante ponto de discordância entre as idéias da democracia direta e as idéias de Siéyès, para quem a superioridade da representação dar-se-ia pelo fato de esta ser a forma de governo mais apropriada às modernas "sociedades mercantis", nas quais os indivíduos estão muito mais ocupados com a produção e a troca econômica, não sobrando tempo para dedicar às questões políticas. Assim, o ideal seria a "política como profissão": através das eleições seria possível que pessoas capazes de devotar todo o seu tempo à política governassem (MANIN, 1997, p.3).

Manin afirma que o que realmente diferencia a democracia direta da representativa não é o número de pessoas que são selecionadas para governar (se muitas ou todas, no caso da direta ou se poucas, no caso da representativa), mas sim como o processo de seleção se dá: "O que faz um sistema ser representativo não é o fato de poucos governarem no lugar do povo, mas sim o fato deles [os representantes] serem selecionados somente através de eleições" (MANIN, 1997, p.41). Se essas eleições forem concorridas livremente, se a participação for ampla e se os cidadãos desfrutarem das liberdades políticas, então o governo eleito representará os eleitores e agirá de acordo com os interesses da população (MANIN et al, 2006, p.106).

O que hoje chamamos de democracia representativa teve sua origem num sistema de instituições estabelecidas por ocasião das revoluções inglesa, americana e francesa, instituições estas que, ao menos inicialmente, não estavam atreladas à idéia de democracia direta (MANIN, 1997, p.1). Neste processo, a forma de seleção de representantes vitoriosa foi a eleição. $\mathrm{Na}$ verdade é espantosa a maneira como, desde os primeiros momentos do estabelecimento da democracia representativa, a possibilidade do sorteio como método de seleção de representantes não foi, sequer, cogitada por seus fundadores, nem mesmo combinado com outras instituições. Mas por que razão? Poderia-se afirmar que o sorteio 
seria incompatível com os Estados modernos, que seria possível apenas em pequenas comunidades, onde todos os membros se conhecessem e onde as funções políticas fossem simples e não demandassem nenhuma competência em especial. Porém, cidades e até mesmo países dos séculos XVII e XVIII podiam não diferir muito, em termos populacionais e de complexidade, das antigas cidades que adotavam o sorteio como método de seleção, o que comprova que a diferença entre as sociedades que adotaram o sorteio e as que não adotaram não residia no tamanho do território ou no número de habitantes, mas sim na crença a respeito de o que torna uma autoridade coletiva legítima. Os atores políticos dos séculos XVII e XVIII não consideravam o sorteio como uma possibilidade, sendo a eleição encarada por eles como o único caminho a ser seguido, e isso se deu devido a crenças e valores que estes atores compartilhavam nesse momento: a idéia central que norteou a adoção da eleição como melhor método de seleção de representantes é a de que a legitimidade da autoridade provém do consentimento daqueles sobre os quais ela é exercida, e a melhor maneira de alcançar tal consentimento seria através do voto. No caso do sorteio, este consentimento não existiria: o que existiria seria um consentimento sobre o método de seleção, ou seja, os cidadãos consentiriam em escolher seus representantes através de sorteio, mas as pessoas sorteadas não teriam sido colocadas no poder através do consentimento dos cidadãos. Desta maneira, surgia um novo conceito de cidadania: o tipo de igualdade privilegiada seria o do direito igual de consentir o poder a outrem e, apenas em menor escala, o direito de concorrer a um cargo (MANIN, 1997, p.92).

Devemos ressaltar que, tanto para Siéyès como para Madison, o governo representativo não é um tipo de democracia, mas sim uma forma essencialmente diferente e preferível de 
governo $^{24}$. No século XVIII um governo organizado em linhas representativas era visto como radicalmente diferente da democracia. O significado moderno e o significado do século XVIII compartilham as noções de igualdade entre os cidadãos e de poder do povo. Hoje essas noções são elementos da idéia democrática, logo a questão está em discernir como os princípios do governo representativo estão relacionados com estes elementos da idéia democrática.

De acordo com Bernard Manin (1997, p.7; 1995, p.4), se analisarmos a história do governo representativo desde sua origem, no final do século XVIII, encontraremos quatro fatores que, segundo sua avaliação, estariam presentes nesta forma de governo desde sua origem e praticamente nunca foram postos em questão desde então. É importante ressaltar que estes fatores não eram simples tipos ideais, mas sim idéias que foram colocadas em prática através de instituições concretas. Analisaremos agora, quais são estes quatro fatores e suas características.

1) Os representantes são eleitos pelos governados. Aqueles que governam são selecionados via eleições que ocorrem em intervalos regulares de tempo: um sistema eletivo não cria uma identidade entre os que governam e os que são governados, o que não significa que os cidadãos comuns têm apenas uma posição

\footnotetext{
${ }^{24}$ Em Urbinati (2006a) encontramos a idéia de que "a democracia representativa é uma forma de governo original, que não é idêntica à democracia eleitoral” (URBINATI, 2006a, p.191). Enquanto a modelo eleitoral de democracia conta com a presença do elitismo nas instituições políticas (domínio da competência), com a idéia de legitimação popular através do voto (domínio do consentimento), além de fundamentar-se na idéia de domínio da divisão do trabalho e em uma seleção funcional de expertise, o modelo representativo, por outro lado, busca evitar a concentração da fonte de legitimação nas instituições estatais e a redução do consentimento popular a um ato de autorização. Para esta corrente, o fundamento da representação se encontra na teoria do consentimento e as eleições se configuram como uma maneira de participar, em algum nível, da produção das leis e sua função seria não a de tornar a democracia mais democrática, mas sim a de torná-la possível. Além disso, a representação seria uma combinação de deliberação e voto, de autorização formal e influência informal, conectando sociedade e instituições, representados e representantes.
} 
subordinada no governo representativo. Embora o povo não governe, a ele não cabe somente o papel de designar e autorizar os que governam, pois o governo representativo se fundamenta em eleições repetidas, o que propicia ao povo condições de exercer uma certa influência sobre as decisões do governo, podendo destituir os representantes cuja orientação não lhe agrade. Além disso, o governo representativo pode ser um governo de elites, mas cabe aos cidadãos comuns decidir que elite vai exercer o poder, ou seja, é o fim da idéia de governo baseado em poderes divinos, riqueza ou conhecimento, e o início da idéia de governo através do consentimento dos governados.

A opção dos fundadores do governo representativo, de instituírem a eleição como método de seleção de representantes, ao invés de sorteio - considerado o método de seleção democrático por excelência até o século XVIII -, demonstra que eles não viam incompatibilidade alguma entre representação e governo de elites, desde que, vale frisar, este governo de elite tenha o consentimento dos governados e governe não de acordo com seus interesses particulares e nem exerçam o governo devido a suas qualidades de distinção.

2) Os representantes conservam uma independência parcial diante das preferências dos eleitores. O processo de tomada de decisão daqueles que governam mantém um certo grau de independência em relação ao desejo do eleitorado: apesar de serem escolhidos, e poderem ser destituídos pelos governados, os representantes mantêm um certo grau de independência em suas decisões. Este princípio se traduz na rejeição, desde o fim do século XVIII, de duas práticas que igualmente privariam os representantes de qualquer autonomia de ação: os mandatos imperativos e a revogabilidade permanente e discricionária dos eleitos, a "recall". 
Durante o século XVIII firmou-se e consolidou-se na Inglaterra a idéia de que os deputados representavam a nação inteira, e não apenas o distrito eleitoral que o havia eleito. Sendo assim, os distritos não estavam aptos a darem instruções aos deputados (MANIN, 1995, p. 6) De fato, algumas tentativas de implementação de leis que obrigassem os candidatos a cumprirem suas promessas, quando eleitos, foram feitas desde então mas, ainda que houvesse a possibilidade de os eleitores ficarem livres para darem instruções aos candidatos eleitos, o cumprimento de tais instruções nunca recebeu caráter legal.

De qualquer maneira, é possível criar instituições e mecanismos que ampliem o poder de controle do eleitorado sobre seus eleitos, porém, por razões de princípio, estas ou não foram estabelecidas ou não encontraram sucesso quando implementadas. O fato é que em nenhum sistema democrático os políticos são obrigados a cumprirem com sua plataforma de campanha: não há lei que obrigue os representantes a cumprirem suas promessas de campanha ou a seguirem instruções, e as ações judiciais movidas por cidadãos contra governantes, por estes não terem cumprido as promessas específicas de campanha, têm sido rejeitadas por tribunais de diversos países (MANIN et al, 2006, p.117). A partir do momento em que os representantes são eleitos, não existem mecanismos institucionais que os obrigue a seguirem o que propuseram em campanha, mas qual o motivo da ausência de tais mecanismos? Se analisarmos historicamente observaremos que a principal justificativa para a ausência destes mecanismos é o fato de que deveria ser permitido aos legisladores deliberar, assim, eles poderiam trocar informações e aprender uns com os outros e também com peritos, aperfeiçoando suas idéias e, conseqüentemente, seu governo. Outra justifica histórica está ligada aos temores dos 
eleitores. Temor de seus próprios julgamentos, que podem ser direcionados pela paixão ou pela sua ignorância reconhecida em um ou diversos assuntos de governo. Outro motivo seria a impossibilidade de se prever o que ocorrerá quando o candidato assumir o poder. Os candidatos, de maneira geral, não sabem o que enfrentarão uma vez no governo, não sabem quais são as reais condições políticas que assumirão e não sabem que tipo de adversidades poderão vir a enfrentar em seu governo. Sendo assim, não podem prever tudo na plataforma de campanha e nem cumprir tudo, caso a situação não favoreça a política inicialmente proposta. Assim, espera-se que os representantes gozem de alguma flexibilidade para adaptarem seu governo da maneira que melhor corresponda aos interesses dos governados no caso de alguma adversidade (MANIN et al, 2006, pp.118-119).

Deste modo, existem boas razões para que não haja a obrigatoriedade de cumprimento da plataforma de campanha. Num governo representativo os representantes esperam que seus eleitos sejam efetivamente capazes de representálos e de governar. O que pode vir a fazer com que os representantes procurem desviar-se o menos possível do projeto inicialmente proposto é a possibilidade de não reeleição (MANIN, 1995, p.7).

De qualquer maneira, é interessante observar a opinião de Madison e Siéyès no que se refere à autonomia dos representantes frente aos representados. Madison acredita que um dos objetivos do sistema representativo, de acordo com o proposto na Constituição dos Estados Unidos, é

colocar no poder pessoas mais aptas a resistir às "paixões desordenadas" e aos "equívocos e ilusões efêmeros" que podem tomar conta do povo: somente deveria prevalecer o "julgamento sereno e ponderado da coletividade". Não 
resta dúvida de que, na sua opinião, não é papel do representante votar da maneira como o povo desejaria em todas as ocasiões. A superioridade do sistema representativo se encontra no fato de permitir um distanciamento entre as decisões do governo e a vontade popular. (MANIN, 1995, p.9)

Siéyès, por sua vez, observa que

não é função dos representantes agir como meros transmissores da vontade dos eleitores. "É portanto incontestável", diz ele, "que os deputados não estão na Assembléia Nacional para afirmar vontades já formuladas por seus eleitores, mas para deliberar e votar livremente, de acordo com o juízo que façam no momento e esclarecidos por todas as luzes que a Assembléia possa lhes proporcionar". (MANIN, 1995, p.9)

Sendo assim, a relativa autonomia dos representantes sobre os representados é vista como algo positivo à representação, pois permite aos representantes a possibilidade de direcionar suas políticas de acordo com a situação que encontram, uma vez no governo, além de se esperar que esta autonomia livre o sistema representativo da influência de vontades direcionadas pela paixão ou pelo desconhecimento de causa que poderiam guiar as opiniões dos governados.

3) A opinião pública sobre assuntos políticos pode se manifestar independentemente do controle do governo. Os governados devem expressar suas opiniões e aspirações políticas sem que estas sejam objeto de controle por parte daqueles que governam: a liberdade de opinião política requer dois elementos, quais sejam o acesso à informação política e a liberdade de opinião pública. Para que os governados possam formar sua opinião sobre assuntos políticos, é necessário que tenham acesso à informação política, o que supõe tornar públicas as decisões governamentais, e também é necessário que gozem de liberdade para expressar sua opinião política. 
A liberdade de expressar a opinião política é a "liberdade positiva", nos termos de Isaiah Berlin, pois diz respeito ao modo de participação dos cidadãos no governo. A Primeira Emenda da Constituição dos Estados Unidos estabelece que "o Congresso não aprovará nenhuma lei que vise à oficialização de uma religião ou que proíba sua livre prática; que limite a liberdade de expressão ou de imprensa; ou o direito de reunião pacífica e o direito de petição" (MANIN, 1995, p.11). É interessante notar que a expressão individual e a expressão coletiva estão vinculadas nesta formulação, quando a liberdade de religião, aplicada a indivíduos, é associada aos direitos de reunião, que são manifestações coletivas. É exatamente o caráter coletivo de uma manifestação que faz dela um ato político, pois o governo pode perfeitamente ignorar manifestações individuais ou dispersas, mas quando as manifestações são coletivas, é impossível - ou, ao menos, muito difícil - ignorá-las. Assim, além de garantir aos cidadãos a "liberdade negativa" (no que se refere à liberdade de culto), a Primeira Emenda garante aos cidadãos a liberdade de agir de maneira ativa diante do governo, expressando sua opinião. Importante frisar que a liberdade de opinião funciona como uma compensação à ausência do direito de instrução por lei: o governo não é obrigado a agir de acordo com os desejos dos governados, mas também não pode ignorá-los, pois, apesar de o voto ser a única vontade verdadeiramente impositiva dos cidadãos, aos governados é garantido o direito de manifestar sua opinião a qualquer momento, por mais que esta vá contra a posição do governo. Assim, a opinião pública conecta os representados e, quando os representados agem como grupo e manifestam sua opinião, independentemente desta coincidir ou não com a dos representantes, eles estão agindo como entidade política capaz, independente de seus representantes e, quanto mais o cidadão estiver 
ciente da opinião dos demais cidadãos, maior será o incentivo do governo para levar essas opiniões em conta no momento de decidir que rumo tomar em suas decisões políticas. Deste modo, representado e representantes não se substituem mutuamente e é mantida a distância e a independência entre eles (MANIN, 1995, p.12-13).

É evidente que o direito de manifestar opiniões e a consciência da possível similaridade dentre essas opiniões não é condição suficiente para que haja uma organização e ação por parte dos representados mas é, sim, condição necessária para que isto aconteça. Para que possamos compreender o poder que esta consciência pode exercer, basta percebermos que em regimes ditatoriais uma das maiores preocupações é evitar a comunicação dentre os cidadãos, pois é reconhecida sua capacidade de conectar indivíduos, e a possibilidade de que esta conexão de idéias leve à organização de um grupo com força frente ao governo é real (MANIN, 1997, p.170-171).

Podemos dizer que a expressão da opinião política compartilhada pelos cidadãos raramente corresponde à opinião de todos os cidadãos ou da maioria deles e, na maior parte do tempo, a expressão da opinião pública manifesta, na verdade, o ponto de vista de um grupo, ainda que ele possa ser grande. O eleitorado, como um todo, raramente se expressa fora da situação da eleição. Dentre as principais formas de manifestação da opinião pública encontram-se a organização de manifestações ou passeatas, as assinaturas em petições e as opiniões expressas através de pesquisas de opinião. No caso das manifestações e das petições o que temos é um pequeno grupo de pessoas - que podem ser intelectuais, lideranças políticas, celebridades de algum meio, etc - que tomam a iniciativa de construir determinada posição frente a algum tema e solicitam a expressão da mesma opinião por parte de um grupo maior. No 
caso das pesquisas de opinião o que temos são manifestações que passaram pelo filtro de seleção dos institutos de pesquisa: os entrevistados não dão sua opinião sobre o que bem entendem, pois são questionados apenas sobre temas préselecionados e delimitados pelos responsáveis pela pesquisa. Ainda que um pequeno número de pessoas sejam entrevistadas, os resultados da pesquisa pode se estender ao todo graças a ferramentas metodológicas e estatísticas. Porém, o desenho da pesquisa e o desenvolvimento das ferramentas utilizadas para a coleta de dados tanto roteiros, no caso de pesquisas qualitativas, quanto questionários, no caso de pesquisas quantitativas - são feitos por um determinado número de pessoas, quais sejam, os profissionais dos institutos de pesquisa e seus clientes. Ainda que toda a população possa expressar sua opinião, os assuntos sobre os quais estarão refletindo são delimitados por um pequeno grupo: as alternativas são por eles delimitadas (por mais que sejam utilizadas ferramentas de pesquisa qualitativa, que parecem ser mais flexíveis sob o ponto de vista do entrevistado, ainda assim os temas e o roteiro a serem seguidos delimitam a direção e a amplitude das opiniões que podem ser expressas naquele contexto). Críticos da pesquisa de opinião afirmam que esta é apenas mais uma maneira de manipular a opinião pública, uma vez que a linha de pesquisa é direcionada por um pequeno grupo e, além disso, os entrevistados podem responder com o intuito de agradar o entrevistador ou devido ao receio de parecerem ignorantes. De fato, riscos existem, mas não menos quanto existem no caso das manifestações ou das petições, uma vez que todas estas modalidades de expressão da opinião pública são, na verdade, solicitadas ao invés de espontâneas. Ainda assim, essas opiniões são levadas em conta pelos governantes no momento de tomada de decisão, ou porque eles sabem que essas opiniões expressas irão se 
disseminar, ou porque o grupo cuja opinião é expressa é fortemente organizado e influente, ou porque uma série de pesquisas apontam para uma tendência no que se refere ao resultado das próximas eleições.

4) As decisões políticas são tomadas após debate. Decisões públicas devem ser submetidas ao julgamento do debate: ainda que o debate não figure com tanto relevo no pensamento dos fundadores do governo representativo quanto no das análises do século XIX, é evidente que, desde suas origens, a idéia de representação esteve ligada à da discussão, ao debate.

Os representantes gozam de maior liberdade de debate dentro das assembléias, logo, as assembléias desempenham papel decisivo no governo representativo e a ligação existente entre representação e debate só pode ser compreendida quando introduzimos a noção intermediária de assembléia. Manin (1995, p.14) diz que Carl Schmitt e outros analistas posteriores consideram que

a estrutura de crenças que justifica o governo representativo, definido como governo por meio de uma assembléia, seria a seguinte: a verdade deve ser a base da lei, o debate é o caminho mais adequado para determinar a verdade; portanto, o órgão central de tomada de decisões deve ser um local de debates, em outras palavras, uma assembléia. (MANIN, 1995, p.14)

Porém, os primeiros partidários do governo representativo não compartilhavam desta justificativa. Para Locke, Montesquieu, Burke, Madison e Siéyès o debate era visto como uma característica inevitável das assembléias. A idéia de representação sempre esteve associada à idéia de diversidade social: seria uma forma de governo do povo em nações muito populosas e diversificadas, e as assembléias deveriam refletir esta diversidade através da eleição de representantes de diversas regiões e 
grupos sociais. Deste modo, "a natureza coletiva e diversificada do organismo representativo, e não a existência de uma convicção prévia e independente nas virtudes do debate parlamentar, é que explica o papel atribuído à discussão" (MANIN, 1995, p.15). O objetivo, numa assembléia tão diversificada, é o alcance de um consenso. Como a igualdade de vontades está na base da concepção representativa, nenhum indivíduo pode impor suas vontades aos demais, uma vez que a vontade de todos possuem o mesmo peso e, desta maneira, o único caminho para se chegar ao consenso é a persuasão. A igualdade de vontades, que fundamenta a legitimidade das eleições como processo de seleção de representantes, também fundamenta a idéia de que o debate é a forma legítima de interação entre os representantes.

Isso nos mostra que a democracia não é o universo do consentimento. A democracia hoje instituída na maior parte dos Estados é policrática, conseqüência do pluralismo encontrado nas sociedades atuais. Nestas sociedades, tanto o consenso como o dissenso devem encontrar lugar para se manifestarem. Aliás, para que haja consenso é preciso que haja dissenso, e este só é possível onde a liberdade de discordar estiver presente, em outras palavras, o consenso só é real onde o dissenso estiver livre para se manifestar, e um sistema só pode ser considerado democrático de fato onde o consenso é real (BOBBIO, 2000, p.74). Segundo Urbinati:

(...) de fato, uma das características mais importantes do governo representativo é sua capacidade para a resolução das demandas conflitantes das partes, com base em seu interesse comum no bem estar do todo. (URBINATI, 2006, p.218) 
De acordo com Bobbio (2000), um dos defeitos da democracia representativa em relação à direta seria a tendência á formação de pequenas oligarquias, e este defeito seria corrigido apenas pela existência de uma pluralidade de oligarquias. Esta pluralidade explica a existência do dissenso que, desde que mantido dentro de certos limites, não age como destruidor, mas sim como estimulador dentro da sociedade pois, como já dissemos, apenas onde o dissenso é livre para manifestar-se o consenso é real (BOBBIO, 2000, p.73-75). No caso da democracia representativa, o lócus de manifestação desde dissenso e de resolução das demandas conflitantes, com o objetivo de se alcançar consenso, é a assembléia.

No pensamento dos fundadores do governo representativo o debate parlamentar tem a tarefa de produzir consenso, e não é um princípio de tomada de decisões em si. O que faz com que uma proposta se converta em política não é o debate, mas o consenso; consenso, este, que não deve ser universal ou a expressão da verdade absoluta, mas sim a manifestação da vontade de uma maioria (MANIN, 1995, p.17).

De qualquer maneira, dentro de um governo representativo, uma medida só possui caráter de decisão quando, ao final dos debates, conta com o consentimento de uma maioria (MANIN, p.18). E, para que haja o consenso da maioria, é preciso que haja uma minoria que dissente (BOBBIO, 200, p.74). 
Estes são, de acordo com Bernard Manin, os quatro princípios do governo representativo que se mantiveram constantes desde sua origem. É verdade que a representação política mudou menos do que se pensa ao longo de sua existência, porém, Manin nos apresenta três formas de governo representativo com base nestes fatores que se mantiveram constantes e demonstra que existem sim, pequenas peculiaridades no que se refere aos princípios dentro de cada uma dessas formas de governo. Trata-se de tipos ideais, e cada um deles podem ter existido separadamente nas sociedades ou concomitantemente. São eles: o parlamentarismo (parliamentarianism), a democracia de partido (party democracy) e a democracia do público (audience democracy). Analisemos, a partir daqui, este tipos ideais à luz dos quatro princípios do governo representativo apresentados por Bernard Manin.

\section{Parlamentarismo}

Este foi o primeiro tipo de governo representativo instituído. No que se refere è eleição dos representantes pelos governados, neste modelo, as eleições eram concebidas como um meio de conduzir ao governo indivíduos nos quais os cidadãos confiassem. Essa confiança se baseava numa rede de relações locais, na notoriedade social do candidato ou no respeito que despertavam. Assim, as eleições pareciam espelhar uma relação nãopolítica. A identificação entre eleitores e representante é pessoal, e o eleito era uma pessoa que mantinha contato constante com os eleitores, através de uma relação baseada na proximidade local ou ao pertencimento a uma mesma comunidade ou área de interesse, gerando um tipo de identificação que não era produzida pela competição política: era 
anterior a ela. Os representantes destacavam-se devido à sua personalidade, riqueza ou ocupação, deste modo, a qualidade específica dos representantes neste tipo de governo era o prestígio social e a notoriedade local, fazendo com que o parlamentarismo fosse o reino de um tipo particular de elite: os notáveis, e o alvo da confiança dos eleitores era a pessoa do representante.

Estes representantes não agiam, dentro do Parlamento, como porta-vozes dos eleitores, mas sim como seus homens de confiança, o que lhes dava uma ampla dose de liberdade para que agissem de acordo com o que sua consciência e julgamento pessoal definissem ser o mais adequado. Essa liberdade se dá pelo fato de a eleição ter se baseado em um fator não-político, qual seja, o prestígio local. Sendo assim, em se tratando de independência parcial dos representantes, podemos considerar que, no parlamentarismo, esta independência era bastante acentuada.

Como as eleições não eram um método de seleção de representantes baseado em características políticas, mas sim em confiança pessoal, a opinião dos cidadãos a respeito de questões políticas precisavam encontrar outros meios para se manifestar, pois o governo parlamentar implica que, havendo essas opiniões contrárias, elas deveriam ser expressas fora dos momentos de eleição. Assim, os meios que essa liberdade de opinião pública encontrava para se verificar na prática era através de petições, manifestações e campanhas de imprensa. Na realidade, a voz dos representados muitas vezes vociferam questões que não são debatidas dentro do Parlamento e, embora essa divergência tenha sido encarada como uma ameaça à ordem pública ela, na realidade, é essencial para o modelo parlamentar de governo, pois essa opinião pública serve, sim, de inspiração para os representantes, exercendo permanente controle sobre eles. É importante notar que, para que este papel de inspiração e controle se verifique é importante que a liberdade de expressão seja total. Vale 
ressaltar, no entanto, que uma das características deste modelo se encontra no fato de a liberdade de opinião pública encontrar-se, neste caso, atrelada ao risco da desordem pública, pois o risco de desordem e violência é iminente quando o povo se encontra fisicamente nas portas do Parlamento.

Podemos dizer que, neste modelo, as decisões políticas são tomadas após debates, pois,

Como os representantes não estão submetidos à vontade de seus eleitores, o Parlamento pode ser um local de deliberação no sentido pleno da palavra - ou seja, um lugar onde os indivíduos podem moldar seu posicionamento através de discussão e onde o consentimento da maioria é alcançado através da troca de argumentos. (MANIN, 1997, p.205-206)

Para que opiniões divergentes possam ser alteradas até que se chegue a um consentimento sobre determinado tema, é preciso que haja a discussão, e é preciso que as opiniões divergentes possam mudar no decorrer das argumentações. Para isso, é necessário que os representantes gozem, de fato, de liberdade para que possam debater e mudar de idéia. Essa liberdade é possível pelo fato de sua eleição não estar atrelada a promessas de campanha.

Democracia de partido

Devido à extensão do direito de voto houve um aumento do eleitorado que acabou tornando o parlamentarismo algo impossível, devido à dificuldade de se manterem relações 
pessoais entre candidato e eleitores. Os partidos políticos assumiram o papel de organizadores da política e os eleitores não votavam mais em uma determinada pessoa, mas sim em determinado partido. Os representantes são eleitos pelos governados não mais de maneira direta, mas através do intermédio de um partido político. Num primeiro momento houve a crença de que os partidos de massa seriam capazes de, realmente, conduzir o chamado "cidadão comum" ao poder, e nos países onde os partidos de massa se baseavam em divisões de classe, havia a expectativa de que a classe operária poderia, finalmente, ser representada no Parlamento através de seus próprios integrantes. Porém, não foi isso que se verificou. O que ocorreu foi uma espécie de "seleção natural”, na qual os mais aptos dentre os operários subiam ao poder. Na realidade, eles não se tornavam diferentes após obter o poder: eles já eram diferentes antes disso. De acordo com Manin (1997, p.217), Robert Michels demonstrou que essa diferença era apenas expressa através dos partidos de massa pois, através deles, os mais inteligentes, bem-informados e articulados tinham a possibilidade de ascender socialmente através da ocupação de um cargo político. Deste modo, uma elite continua a dominar o poder: se o parlamentarismo era o reino dos notáveis, a democracia de partido é o reino do ativista e líder partidário (chefe político), cujas principais atribuições são o ativismo e a capacidade de organização.

Neste modelo os eleitores não votam mais em determinada pessoa, mas sim em determinado partido, o qual passa a ser depositário da confiança dos eleitores. Com isso, assistimos ao surgimento da estabilidade eleitoral, grande descoberta da ciência política na virada do século, comprovada por pesquisas realizadas até a década de 70 . Os eleitores passam a escolher seus candidatos com base no partido à que pertencem, e a preferência partidária é transmitida de geração em geração. Além disso, a estabilidade social deriva da preferência política determinada por fatores socioeconômicos, sendo que 
Os partidos socialistas ou socialdemocratas são geralmente considerados como os arquétipos do partido de massa contemporâneo, que se transformou, desde o final do século XIX, no núcleo de organização das democracias representativas. Por essa razão, nos países onde os partidos socialdemocratas são fortes é que se pode encontrar a forma mais pura do tipo de representação gerada por lealdades partidárias estáveis. (MANIN, 1997, p.209)

Como exemplo de países onde os partidos socialdemocratas eram fortes, Manin cita Alemanha, Inglaterra, Áustria e Suécia. Para os eleitores o voto não era um questão de escolha, mas sim de identidade social e os eleitores votavam em determinado candidato porque ele pertencia ao partido que representava a clivagem socioeconômica e cultural ao qual eles pertenciam. As diferenças sociais encontravam-se associadas a traços econômicos e culturais, e eram basicamente dois os campos existentes: o conservador (unido por questões religiosas e demais valores tradicionais) e o socialista (unido por questões socioeconômicas). Deste modo, a eleição reflete as clivagens existentes na sociedade, clivagens estas que são anteriores à competição política, e o que determina a preferência por determinado partido não é a plataforma política do mesmo, mas sim a identidade social que ele representa. Os partidos políticos neste tipo de modelo formulavam uma plataforma política detalhada - nisso são bem diferentes dos partidos existentes no modelo parlamentar -, porém os eleitores não sabiam muito sobre essas plataformas, que serviam mais como orientação para os ativistas. O que as eleições determinam, neste modelo, não são quais políticas devem ser postas em prática, mas sim a força relativa dos vários partidos. O fator "confiança" que era observado no modelo parlamentarista também está presente neste modelo, porém, o foco da confiança deslocou-se da pessoa do candidato para a organização partidária. 
Aqui observamos o primeiro momento em que foi levantada a hipótese de crise da representação. Isso se deu pela mudança ocorrida quando a preferência por determinado partido de massa substituiu os vínculos pessoais existentes no parlamentarismo. Logo, a mudança foi interpretada como uma crise. Mas não se tratava de uma crise, e sim de uma transformação na relação existente entre eleitores e representantes.

Esta forte conexão do representante com o partido parece ter reduzido a independência parcial dos representantes à medida em que os indivíduos não são mais livres como eram no modelo parlamentar, quando podiam seguir seu julgamento particular: aqui os representantes devem seguir as determinações dos partidos, agindo, assim, como delegados ou porta-vozes dos partidos. Deste modo, o Parlamento passa a ser o reflexo das forças encontradas na sociedade. É importante observar que, quando posicionamentos são tão fortemente estruturados, o risco de um confronto violento passa a se real, porém, os campos envolvidos na política conhecem perfeitamente sua força e a força de seus oponentes, o que faz com que conheçam o alto custo do confronto. Assim, as partes optam pelo princípio de conciliação política. Além disso, como a maior parte das sociedades que apresentaram esse modelo de governo adotavam o sistema de representação proporcional ${ }^{25}$, que raramente produz uma maioria no Parlamento, a coalizão era uma necessidade real. Assumindo coalizões, os partidos abrem mão de desenvolverem todas as políticas prédeterminadas quando chegam ao poder, pois precisarão ceder para que a coligação possa acontecer. Neste caso, o não cumprimento de todas as promessas de campanha não se configura como um grande problema, pois os eleitores não apenas manifestam sua confiança num determinado partido através do voto, como também desconhecem a

\footnotetext{
${ }^{25}$ A adoção do sistema de representação proporcional tinha o objetivo de refletir a relação de força existente dentro da sociedade.
} 
plataforma política dos partidos. De qualquer maneira, a democracia de partido não reduz a independência dos representantes: o que ocorre é que, ao invés de a pessoa do representante eleito ser o foco da independência, no modelo de democracia de partido este foco deslocase para o partido político. De fato, a independência dos representantes não é tão ampla quanto era no parlamentarismo, uma vez que devem fidelidade às decisões tomadas pelos líderes partidários, mas a independência dos partidos políticos frente aos eleitores é verificada neste modelo.

Assim, os partidos políticos são, de fato, o ator político de destaque neste modelo, pois, além de exercerem poder sobre o posicionamento dos representantes eleitos e de serem os depositários da confiança dos eleitores, eles também organizam os meios de expressão da opinião pública, possuindo importante papel na liberdade de opinião pública.

As associações e os órgãos de imprensa estão ligados aos partidos políticos e apresentam aos eleitores apenas o ponto de vista do partido ao qual estão atrelados. Desta maneira, os eleitores mais bem-informados e os formadores de opinião buscam informações na imprensa atrelada ao partido ao qual são fiéis, ficando muito pouco expostos ao ponto de vista do partido contrário, o que contribui para o fortalecimento da estabilidade das opiniões políticas. Esta é a chamada "imprensa de opinião". À primeira vista temos a impressão de que os cidadãos, neste modelo, não podem falar por si mesmos, pelo fato de as organizações partidárias controlarem os meios de expressão política. Manin nos mostra que isso não é verdade: na democracia de partido quem governa não é mais o Parlamento, mas sim o partido majoritário ou uma coligação de partidos, e o partido que está no poder pode controlar seus canais de expressão, mas não os canais de expressão dos oponentes. Assim, "na democracia de partido, a liberdade da opinião pública manifesta-se sob a forma de liberdade de oposição" (MANIN, 1997, p.216). As vozes dentro e fora do 
Parlamento coincidem dentro de cada campo, mas um campo não pode interferir nas opiniões expressas pelo campo adversário. Trata-se aqui, não do fim da liberdade de opinião pública, mas sim um deslocamento em relação ao modelo parlamentarista.

Outra conseqüência da rígida disciplina partidária é o fim do Parlamento como fórum de debates coletivos: quando os representantes dirigem-se ao Parlamento já sabem qual a decisão tomada pelos líderes partidários e sabem, também, que devem manter-se alinhados com essa posição, independentemente dos debates que possam ser travados. Assim, as sessões parlamentares não são mais o lugar no qual se chega a um consenso da maioria após debate, mas sim o lugar onde ocorrem as votações que conferem o caráter legal a decisões que foram tomadas anteriormente em outros locais, mais especificamente, nas reuniões partidárias, onde os participantes podem, de fato, deliberar ${ }^{26}$.

\section{Democracia do público}

Nos últimos anos têm sido detectadas alterações no padrão dos resultados eleitorais observados até os anos 1970. Até então os resultados eram estáveis de uma eleição para a outra, e as preferências do eleitorado coincidiam com clivagens sociais, econômicas e culturais encontradas na sociedade. Atualmente esta estabilidade eleitoral não é mais verificada, e os resultados tendem a variar de uma eleição para a outra, ainda que se mantenham estáveis as condições sociais, econômicas e culturais do eleitorado. Esta

\footnotetext{
${ }^{26}$ Aqui observamos que o debate que ocorre dentro dos partidos políticos exclui as posições dos demais partidos. Sobre isso Manin diz que "esse modelo de governo representativo incentiva a discussão entre os líderes dos diversos partidos” (MANIN, 1995, p.30).
} 
mudança se deve, principalmente, a dois fatores: a personalização da relação entre representado e representante e os termos da escolha eleitoral.

Nesta forma de governo a escolha é feita com base na pessoa do candidato, e o eleitorado vota de maneira diferente a cada eleição, em cada esfera de poder - federal, estadual e municipal - e para legislativo e executivo, dependendo da personalidade dos candidatos.

Os representantes são eleitos pelos governados com base em sua personalidade, e não mais com base no partido ao qual pertencem. Esta personalização da escolha eleitoral tem sido vista por muitos atores, como políticos, mídia e intelectuais, como uma crise da representação política. Como ocorrera na passagem do parlamentarismo para a democracia de partido - quando a preferência por determinado partido de massa substituiu os vínculos pessoais existentes no parlamentarismo - esta mudança que, na verdade, parece se assemelhar ao que era observado no primeiro modelo, o parlamentarista, é interpretada como uma crise da representação.

O que está em curso, na realidade, é uma transformação da representação política. Se no modelo de democracia de partido os partidos políticos ocupavam o lugar dos vínculos pessoais que existiam no parlamentarismo e não mais eram possíveis devido à ampliação do eleitorado, o que verificamos agora é o retorno aos vínculos pessoais. Os partidos políticos continuam a exercer um papel fundamental na representação, uma vez que possuem o monopólio da representação política (a apresentação de candidaturas a cargos eletivos é monopólio dos partidos políticos), mas passam, agora, a funcionar como instrumento a serviço do líder.

Os veículos de comunicação de massa possibilitaram a comunicação direta entre representante e eleitorado, permitindo o retorno aos vínculos pessoais e dispensando a 
mediação dos partidos políticos. De acordo com Lavalle, Houtzager e Castello (2006), a atribuição de tal papel à mídia encontra suporte não somente nas idéias de Manin, como também nas de Novaro. Para Novaro (2000), a relação entre representante e representado define-se menos por laços de identidade partidária ou setorial e mais por opiniões e interesses que se formam, tornam-se visíveis e circulam nos meios de comunicação. Através dos meios de comunicação a figura do líder passa a ter um papel diferenciado, com o parlamento perdendo sua força enquanto lócus de debate político e os partidos políticos perdendo seu lócus enquanto mediadores e agregadores de opiniões. Ainda para Novaro, haveria uma mudança da imagem midiática de "propagandista", onde a mensagem partidária era transmitida com certo conteúdo ideológico para uma platéia homogênea para uma "mercadotécnica", construindo imagens e personalidades de "produtos", dirigidos a públicos diversos, carentes de interesses comuns definidos. Por fim, o autor diz que o papel positivo ou negativo dos meios de comunicação depende do contexto cultural no qual o processo ocorre, ou seja, onde os partidos políticos são sólidos e capazes de adaptarem-se às mudanças, este papel pode ser positivo, uma vez que colabora nas alterações de ideologias tradicionais, para a dinamização do debate público e para o acesso dos cidadãos à informação. Já em sociedades onde os partidos políticos são debilitados, com negociação de interesses e comportamento pragmático, a tendência é negativa, pois poderá colaborar ainda mais para este quadro, como também para a debilitação ainda maior das instituições e da competência política. Daí a importância em se garantir fortalecimento dos partidos políticos. Ainda que neste novo modelo os partidos políticos possuam o papel de coadjuvantes na representação, a importância dos mesmos para a saúde da democracia representativa também é defendida por Nadia Urbinati, que afirma que os partidos políticos são capazes de traduzir as particularidades numa linguagem que, além de ser geral, tem 
como objetivo representar o geral, uma vez que "nenhum partido político diz representar apenas os interesses daqueles que a ele pertencem ou o apóiam" (URBINATI, 2006a, p.219), e seu desaparecimento seria altamente indesejável, pois poderia causar um afastamento dos princípios do governo representativo, à medida em que candidatos avulsos, sem um partido político por trás, poderiam apenas representar seus interesses pessoais, e não mais o interesse coletivo. "O arranjo legislativo seria uma agregação de vontades individuais, mais ou menos como a assembléia da democracia direta" (URBINATI, (2006a, p.223).

A televisão fez com que emergisse um novo tipo de liderança política: a personalidade do candidato passou a ter papel especial, e o domínio da melhor maneira de se comunicar com os eleitores através da mídia passou a ser determinante nos processos eleitorais. Deste modo, o que temos observado não é o abandono dos princípios do governo representativo, mas sim a mudança do tipo de elite selecionada: a democracia do público é o reino do comunicador. Além disso, os candidatos e os próprios partidos políticos passaram a dar maior ênfase à individualidade dos políticos em detrimento da plataforma política: devido à complexidade das sociedades modernas, que vem tornando mais complexas não apenas as relações internas destas sociedades, mas também as externas.

Com o fenômeno da globalização, a interdependência econômica e até mesmo política entre as nações têm mudado o cenário onde as políticas são idealizadas e implementadas: cada vez mais atores que tomam diferentes decisões, que devem ser levadas em conta, são agregados ao processo, mudanças ocorrem rapidamente e os problemas enfrentados são cada vez mais imprevisíveis, o que torna praticamente impossível que se siga o plano de governo pré-estabelecido à risca. Neste ponto Manin nos chama a atenção para o fato de a ação do governo, neste novo quadro, demandar poder 
discricionário, que se assemelha muito à idéia de prerrogativa tal qual definida por Locke. A idéia de prerrogativa está associada à autoridade para tomar decisões na ausência de legislação (MANIN, 1995, p.32). No caso dos governos contemporâneos, como já vimos anteriormente, é cada vez mais difícil prever que situações serão enfrentadas ao longo de um mandato, sendo necessário que os políticos gozem de um poder discricionário frente aos programas políticos. Os próprios eleitores estão cientes de que os governantes terão que enfrentar situações imprevisíveis e, por essa razão, o melhor processo de escolha eleitoral não é baseado nos programas políticos - que podem mudar, dependendo das circunstâncias - mas sim a confiança pessoal depositada no candidato, confiança que leva os eleitores a crerem que o representante poderá dar conta dos problemas inusitados que venha a enfrentar. Assim, mais uma vez, a mesma confiança encontrada nos dois modelos anteriores de representação aparece com importância decisiva dentro das relações entre eleitorado e representante. Vale ressaltar que poder discricionário não é o mesmo que poder irresponsável, uma vez que os eleitores continuam sendo detentores do poder de destituir os representantes quando seus mandatos chegam ao fim. Deste modo, "os eleitores determinam a posteriori, reelegendo ou destituindo o representante, se as iniciativas por ele tomadas promoveram ou não o bem público" (MANIN, 1995, p.33).

O outro fator responsável pela mudança verificada neste modelo de representação, em relação ao anterior, são os termos gerais da escolha racional: o fato de o eleitorado votar de maneira diferente a cada eleição, em cada esfera de poder - federal, estadual e municipal - e para legislativo e executivo, demonstra que o que está em jogo é a percepção de uma eleição específica, e não as clivagens sociais, econômicas e culturais, nem as ideologias partidárias. A maneira como os eleitores votam muda significativamente num curto espaço de tempo, sugerindo que os eleitores têm assumido mais a posição de responder aos 
estímulos dos políticos do que a de expressar suas identidades. Cabe aos candidatos construírem uma imagem que, além de diferenciá-los dos demais concorrentes, seja capaz de atrair o maior número possível de votos. É necessário que os candidatos se identifiquem e identifiquem os concorrentes nesta construção, pois são as diferenças detectadas neste processo que deverão ser trabalhadas com o objetivo de mobilizar adeptos. Se antes era possível detectar identidades sociais, econômicas e culturais dentro da sociedade, isso agora se tornou bastante difícil, devido ao fato de as diversas linhas de demarcação serem muito numerosas, se entrelaçarem e mudarem com muita rapidez, conferindo um caráter fluido aos possíveis pontos de corte que os candidatos podem adotar para desenvolver sua campanha.

Assim, quem determina os termos da escolha eleitoral são os políticos, e não o eleitorado. Cabe aos políticos, munidos de ferramentas como as pesquisas de opinião, detectarem que linha de clivagem apresenta maior potencial para conduzi-lo à vitória no processo eleitoral. Os candidatos que fazem uma má escolha neste ponto acabam perdendo as eleições. É importante ressaltar que essas clivagens não podem ser "inventadas" pelos candidatos: elas devem ser reais, devem de fato existir na sociedade. Caso contrário, o caráter artificial de tal clivagem será detectado e, provavelmente, rejeitado pelos eleitores, devido à extrema falta de identidade apresentada. Os candidatos não sabem de antemão quais são as clivagens que podem mobilizar eficazmente o eleitorado, mas têm muito interesse em descobrir quais são essas questões que melhor dividem o eleitorado, com o objetivo de explorá-las politicamente. Para que possam saber quais são essas clivagens os políticos lançam mão da pesquisa de opinião. Nesta descoberta é adotado o processo de ensaio e erro, no qual os políticos propõem uma divisão que os institutos de pesquisa testam e, dependendo da reação do público, o político mantém a proposta inicial, realiza 
alterações ou, até mesmo, a descarta e elabora outra proposta. Aqui, como nas outras formas de governo representativo, o voto continua a ter um caráter reativo, quer seja em relação aos estímulos de campanha, quer seja em relação às políticas efetivamente colocadas em prática ao longo do governo. Um dos instrumentos que os eleitores têm a sua disposição para controlar as ações de seus candidatos eleitos é a prestação de contas $(\text { accountability })^{27}$. Neste sentido "as eleições constituem um mecanismo de sanção sobre os representantes (accountability) e tendem a estimular a sensibilidade destes perante as demandas e necessidades dos representados (responsiveness)" (LAVALLE et al, 2006, p.55). Neste caso o voto possui caráter retrospectivo, com os eleitores estabelecendo alguns parâmetros que os permita avaliar o desempenho do governo (MANIN et al, 2006, p.121). Porém, as eleições não são, per se, um mecanismo eficaz para garantir que os governantes venham a atuar de maneira responsiva frente aos seus eleitores (MANIN et al, 2006) e, por essa razão, é preciso que existam outros mecanismos capazes de assegurar essa atuação responsiva como, por exemplo, a existência de uma legislação eficiente e de instituições de fiscalização e sanção independentes.

Para que a prestação de contas possa apresentar uma eficácia real faz-se necessário o preenchimento de um pré-requisito: o da informação, o que faz com que a mídia, mais uma vez, ocupe lugar de destaque neste modelo de representação. Quando os representados possuem informações satisfatórias sobre o que está se processando, é verificado accountability, porém, quando os mesmos não detêm esta informação, o accountability não é suficiente para garantir a representação. Deste modo, faz-se necessária a disseminação de informação, bem como a existência de um canal que permita a conexão entre representados

\footnotetext{
27 "Nesse enfoque, os cidadãos estabelecem algum parâmetro de desempenho para avaliar os governantes"
} (MANIN et al, 2006, p.121). 
e representantes, além da existência de instituições que favoreçam a transparência da responsabilidade, instituições, estas, que forneçam informações independentes sobre o governo e que também possibilitem seu controle (MANIN et al, p.2006). É importante notar que os dois movimentos mais notáveis na direção de exercer accountability têm ocorrido fora das agências governamentais de controle horizontal. Esses dois movimentos foram postos em prática pela mídia, através de seu papel de vigilância e pelos atores societários, dedicados ao monitoramento de temas específicos ligados a interesses gerais ou vinculados a determinados grupos. Some-se a estes fenômenos, o das reformas participativas, através das quais os atores da sociedade civil vêm encontrando espaço, inclusive juridicamente, para representar determinados grupos e interesses. Encontramos aqui a perspectiva societária de transformação de baixo para cima. (LAVALLE, et al, p.2006). Surge aqui, também, a questão da necessidade de se pensar e repensar novas instituições democráticas que possam, de fato, colaborar para que uma maior representatividade se verifique na relação entre representados e representante (MANIN et al, p.2006).

Devido a esse caráter reativo do eleitorado, Manin $(1995,1997)$ afirma que a metáfora do mercado, freqüentemente utilizada para analisar a política nas democracias, não é a mais adequada. A metáfora do político como empresário que busca angariar votos e maximizar benefícios, sem dúvidas, faz sentido. O que dificulta a analogia do mercado para a política é a metáfora do eleitor como consumidor. Ao passo que o consumidor entra no mercado sabendo o que deseja, independentemente dos produtos que lhe serão ofertados, com os eleitores não ocorre o mesmo. Quando o eleitor adentra o ambiente da política, suas preferências ainda não estão formadas, e só passam a ser formadas através do debate público: as preferências dos eleitores não preexistem à ação dos políticos. O próprio Joseph 
Schumpeter, considerado o fundador das teorias econômicas da democracia, reconhece que em política não existe propriamente uma demanda. Para ele as pessoas possuem opinião formada sobre assuntos ligados à realidade de seu cotidiano, relacionados ao grupo ao qual pertencem. Mas quando os assuntos escapam a esta esfera mais íntima e passam para assuntos relacionados à realidade nacional e internacional, essa capacidade de volição e o senso de responsabilidade se enfraquecem consideravelmente: as pessoas podem possuir sonhos, inspirações e até mesmo antipatia e simpatia, mas isso não se traduz no que costumamos chamar de "vontade". Schumpeter observa que os eleitores não possuem uma vontade política independente da ação dos políticos e, portanto, esta vontade política é, em grande parte, fabricada, e não espontânea. Sendo assim, de acordo com Manin (1995, 1996), a metáfora mais adequada - ainda que imperfeita - para analisar a política nas democracias é a do teatro. É importante observar que no teatro ou na política, o indivíduo deve afastar-se de si mesmo e do que lhe é semelhante para, assim, estar apto a absorver o estranho: é preciso que se esteja aberto para que haja uma interlocução através da qual seja possível trazer para dentro de si os pensamentos alheios (ARAÚJO, 2006, p.231). De acordo com Cícero Araújo (2006), podemos identificar o representado como um autor e o representante como um ator, sendo este complementado por aquele. Segundo Hobbes,

o autor é o 'ser representado' e uma figura que não deve aparecer em cena, mas que se metamorfoseia inteiramente no 'ser representante' que, então, passa a fazer tudo no 'lugar de' ou 'em nome de' outro". Deste modo, "a fonte da autoridade política, de criador, se torna criatura de sua criatura (ARAÚJO, 2006, p.234). 
Manin diz que "Na democracia do público os representantes políticos são atores que tomam a iniciativa de propor um princípio de divisão no interior do eleitorado. Eles buscam identificar essas clivagens e trazê-las ao palco. Mas o público que, afinal dá o veredicto" (MANIN, 1995, p.37).

O processo de escolha dos representantes observado neste modelo é muito influenciado pelo que chamamos de "imagem", que pode ser do candidato ou do partido político. É importante frisar que esta imagem não é vazia de sentido político, pelo contrário: "as pesquisas de opinião revelam que as imagens elaboradas pelos eleitores não deixam de ter um conteúdo político" (MANIN, 1995, p.38). Numa campanha política os candidatos procuram moldar sua própria imagem, porém, esta não deve ser analisada separadamente: é preciso analisar as imagens criadas por todos os candidatos, uma vez que os eleitores recebem uma variedade de imagens que competem entre si e, a partir dessas informações, molda sua opinião. Uma importante função dessas imagens esta na capacidade que elas possuem de reduzir os custos da informação política. Um dos maiores problemas das democracias contemporâneas reside no alto custo da informação política ${ }^{28}$ que destoa da influência mínima que cada cidadão espera exercer sobre o resultado das eleições. Assim, as imagens, esquematizadas e simplificadas, buscam facilitar o trabalho de busca de informação por parte dos eleitores. Deste modo, no que se refere à independência parcial dos representantes, o fato deles serem escolhidos com base nessas imagens esquematizadas confere-lhes um significativo espaço para que possam agir com liberdade após eleitos, uma vez que "a causa de sua eleição foi um compromisso relativamente vago, que naturalmente se presta a diversas interpretações" (MANIN, 1995, p.39).

\footnotetext{
${ }^{28}$ Manin observa que, nas democracias de partido, este custo elevado da informação política não existe devido ao fato de a decisão dos eleitores definir-se por um sentimento de classe que já existia na sociedade, independentemente das campanhas eleitorais.
} 
Uma diferença fundamental entre a democracia de partido e a democracia do público encontra-se no fator liberdade de opinião pública, mais especificamente no que se refere aos canais de comunicação: enquanto na democracia de partido os partidos políticos possuíam canais de comunicação que veiculavam apenas o ponto de vista próprio, na democracia do público os canais de comunicação são politicamente neutros, despidos de orientação ideológica. Isso faz com que os eleitores estejam todos expostos a informações neutras (o que não significa que não possa haver distorções) e não apenas a informações que estejam de acordo com suas inclinações partidárias. No entanto é importante observar que a percepção do público frente aos acontecimentos pode não possuir ume inclinação partidária, porém, a divergência de opiniões pode existir e, na realidade, freqüentemente é verificada. $\mathrm{O}$ que se observa é que essas divergências tendem a ser desvinculadas da opinião expressa nas eleições, ou seja, "as manifestações eleitorais e não eleitorais do povo podem não ser coincidentes" (MANIN, 1995, p.40). Manin afirma que a principal responsável por esta não coincidência é a neutralização dos canais de comunicação, em especial o caráter não partidarista dos institutos de pesquisa de opinião pública que assumem caráter crucial na expressão da opinião pública nas democracias contemporâneas. Aqui, mais uma vez Manin lança mão da metáfora do teatro, ao afirmar que a relação existente entre os responsáveis pela pesquisa e os entrevistados: os responsáveis pela elaboração dos questionários ${ }^{29}$ não sabem, de antemão, quais questões poderão levá-los de maneira mais satisfatória ao objetivo de definir clivagens significativas na sociedade.

\footnotetext{
${ }^{29}$ Vale ressaltar que, quando os assuntos a serem abordados pela pesquisa quantitativa, através de questionários, são muito obscuros, ou quando espera-se confeccionar um questionário mais eficaz e objetivo, os institutos lançam mão de uma prévia sob a forma de pesquisa qualitativa. Essa fase qualitativa costuma se dar através dos chamados focus group, que consistem na formação de grupos de discussão com um número reduzido de pessoas (normalmente até 10) que debaterão a respeito do tema proposto através da orientação de um mediador que seguirá um roteiro com o objetivo de direcionar a discussão de maneira a compreender que pontos deveriam ser abordados no questionário para validação através de pesquisa quantitativa.
} 
Assim como os políticos, os pesquisadores trabalham por ensaio e erro. (MANIN, 1995, p.40).

Essa não coincidência entre as manifestações eleitorais é um outro ponto de convergência entre a democracia do público e o parlamentarismo, ainda que as pesquisas de opinião confiram um caráter bastante peculiar à manifestação da expressão não eleitoral. “As pesquisas reduzem os custos da expressão política individual” (MANIN, 1995, p.41), pois os custos de responder a uma pesquisa anonimamente - que costuma ter uma curta duração (alguns minutos) e costuma ser aplicado em locais de grande fluxo, como o trajeto de casa para o trabalho, ou na porta de casa, ou ainda por telefone ou até mesmo via Internet - é bastante baixo. Além disso, as pesquisas de opinião dão voz ao cidadão apático que, normalmente, não teria sua opinião levada em consideração. Além disso, as pesquisas, diferentemente das manifestações observadas no modelo parlamentarista, são pacíficas e fazem com que os cidadãos estejam presentes com mais freqüência "nas portas do Parlamento", porém, não fisicamente como ocorre no parlamentarismo, mas sim através da divulgação de constantes pesquisas de opinião.

A neutralidade dos canais de informação tem contribuído para a formação de um novo protagonista dentro do governo representativo: o eleitor flutuante, e esses meios de comunicação de massa têm assumido o papel de novo fórum de discussão. $\mathrm{O}$ eleitor flutuante caracteriza-se pela instabilidade de suas decisões políticas e não é privilegio da democracia do público: ele já existia nos outros modelos, porém, com uma diferença fundamental - se antes o eleitorado instável era composto por cidadãos poucos informados, pouco interessados em política e com baixo grau de escolaridade, na democracia do público o eleitorado instável é composto por cidadãos bem-informados, interessados em política e razoavelmente instruídos, o chamado eleitorado flutuante. Os meios de comunicação de 
massa têm assumido o papel de fórum de discussão, pois, neste modelo, o debate ocorre no meio do povo, e não está mais restrito aos muros do Parlamento, aos debates intrapartidários ou, ainda, às comissões consultivas entre partidos.

De acordo com Urbinati (2006a), a representação política vai contra a idéia de que os cidadãos agem de maneira racional, como unidades separadas que agregam opiniões de maneira instrumental e também contra a idéia de que a representação acontece porque estes mesmos cidadãos formam uma massa de unidades dissociadas que delegam seu poder pelo fato de uma multidão ser incapaz de ser um governo. Na verdade, a representação encara a sociedade como um conjunto complexo, com diferentes idéias e opiniões - com consenso e dissenso -, passíveis de se alterarem ao longo do tempo - eis aí o pluralismo social - daí o fato de a democracia ser a única forma de governo que extrai das diferenças a força para a sua existência. Uma teoria da democracia representativa requer, ainda, uma nova definição de soberania popular, que encerre a idéia de política como um jogo de "sim" e "não" e a defina como uma arena de debates e reflexões, onde possa haver este consenso e dissenso e onde as opiniões possam ser reavaliadas quando necessário for. Segundo Urbinati (2006b), o motor central para democratizar a representação é conceber a soberania popular como um princípio regulador que guia o julgamento político e as ações do cidadãos e esta nova concepção de soberania popular deve colocar o povo como sendo o centro de gravidade de toda a sociedade democrática. Essa concepção despreza a idéia de que eleitores ocupem o lugar que cabe aos cidadãos neste centro de gravidade e afirma que o ato da autorização é mais importante do que o processo de autorização (URBINATI, 2006b, p.25). A autora também afirma que, numa forma de governo cuja legitimidade provém das eleições, a existência de um canal de comunicação entre a sociedade política e a sociedade civil é algo 
essencial. Este canal pode se dar através "da mídia, movimentos sociais e partidos políticos" (2006a, p.202).

Por fim, Manin (1995, p.42) afirma que a idéia recorrente de crise da representação se deve à percepção de que o governo representativo vem se afastando do governo do povo pelo povo, porém, é preciso compreender que a representação não foi concebida como uma forma mediada de autogoverno do povo: "O governo representativo não foi concebido como um tipo particular de democracia, mas como um sistema político original baseado em princípios distintos daqueles que organizam a democracia" (MANIN, 1995, p.42). Com o advento dos partidos de massa o que se verificou foi a disseminação da idéia de que o governo representativo caminhava rumo à democracia, porém, ao analisarmos os princípios do governo representativo, verificamos que eles mantiveram-se fortes nos três modelos aqui analisados, o que houve foi um "deslocamento e um rearranjo da mesma combinação de elementos que sempre esteve presente desde o final do século XVIII" (MANIN, 1995, p.42).

\subsection{Democracia, poliarquia e igualdade política}

Tratamos até aqui da questão da representação política e concluímos que o que está em curso não é uma crise da representação política, mas sim transformações no governo democrático representativo que levaram ao que Bernard Manin convencionou chamar de democracia do público. 
John Rawls, ao tratar da justiça política e da constituição (forma de justiça procedimental imperfeita), afirma que os cidadãos devem gozar do princípio da (igual) participação $^{30}$, que exige que todos os cidadãos tenham igual direito de tomar parte no processo constitucional, que deve ocorrer dentro de uma democracia constitucional, cujos elementos - componentes da representação - devem ser uma assembléia representativa com poderes legislativos, além de partidos políticos que efetivamente formulem uma concepção do bem público (RAWLS, 1993, p.183). Aliado a isso, verificamos que os direitos e valores políticos democráticos são protegidos pelo primeiro princípio da justiça, logo, podemos concluir que a justiça como eqüidade é compatível com o regime democrático representativo.

Levando em conta o fato de a representação - pilar central da democracia representativa - não estar efetivamente em crise, e o fato de a justiça como eqüidade ser compatível com o regime democrático representativo, podemos afirmar que a busca pelo aperfeiçoamento do método democrático, tendo em vista a produção de resultados mais justos, não requer que se encontrem alternativas ao governo democrático representativo, mas sim que se encontrem maneiras de aperfeiçoá-lo para que possamos obter os resultados desejados. Encontramos suporte para esta afirmação na análise que Álvaro de Vita desenvolve em torno da questão "sob que condições é de se esperar que a democracia produza resultados políticos justos?" (VITA, 2003, p.111), sob a ótica do liberalismo igualitário e das diversas concepções de democracia deliberativa. O autor descarta o argumento de que, para que haja a promoção de resultados políticos justos, seja necessária a substituição da democracia competitiva pela democracia deliberativa e defende a idéia de

\footnotetext{
${ }^{30} \mathrm{O}$ princípio da (igual) participação fundamenta-se na idéia de que, se o Estado exercerá uma função coercitiva no território sob seu domínio, afetando a expectativa de vida das pessoas, então o processo constitucional deve preservar a representação igual, presente na posição original.
} 
que a melhor alternativa para se alcançar este objetivo seria a criação de "condições mais eqüitativas para que os cidadãos influenciem as decisões políticas e constituam preferências informadas sobre as questões mais importantes de política pública” (VITA, 2003, p.117). É evidente que a deliberação é vista com bons olhos, sobretudo se ela funcionar como um método para revelar respostas corretas a questões controversas, além de poder contribuir nos casos em que não é possível alcançar um entendimento, para que os participantes melhor aceitem os resultados. Porém, estas características desejáveis da deliberação só podem se manifestar em fóruns específicos e restritos, nos quais o debate leve em consideração argumentos e opiniões de especialistas alem do comprometimento com métodos de aferição de evidências. Exemplos deste tipo de fórum seriam a Comissão de Constituição e Justiça do Senado brasileiro, pequenas comunidades críticas que assessoram a formulação de políticas públicas, etc. A questão que devemos fazer neste ponto é: é razoável esperar que os cidadãos participem de práticas deliberativas que tenham como objetivo a tomada de decisões a respeito de políticas públicas? (VITA, 2003, p.118).

Se o que desejamos é que haja mais deliberação dentro do processo político, no que se refere à tomada de decisões políticas, a democracia competitiva pode perfeitamente prestar-se a este papel. Mas se a questão for trazer os cidadãos para a deliberação, substituindo os representantes, então poderíamos fazer as mesmas críticas que cabem à democracia direta. Em primeiro lugar, se a justificativa dada à deliberação for baseada na concepção de democracia deliberativa como um ideal moral, como um fim em si mesmo, então estaremos realizando um juízo de valor, pois devemos considerar que existem várias formas de vida que podem ser adotadas, e muitas delas não passam por esta questão, uma vez que muitos cidadãos podem considerar alienante ter de se envolver em processos participativos e deliberativos. Em segundo lugar, é preciso levar em conta o déficit 
motivacional e cognitivo envolvido, pois o objeto dessa deliberação são questões de políticas públicas, muitas vezes demasiado complexas e distantes da vida cotidiana dos cidadãos. Por fim, existe a desigualdade de ativismo político, que também possui efeito distributivo, à medida em que os cidadãos politicamente mais ativos são mais capazes de defender seus interesses e se fazerem ouvir pelas autoridades políticas. É importante ressaltar que

\footnotetext{
"os níveis desiguais de participação política se devem, em larga medida, à distribuição muito desigual de recursos políticos cruciais tais como renda, riqueza, educação, recursos cognitivos, tempo livre para a atividade política, facilidade maior ou menor de superar problemas de ação coletiva." (VITA, 2003, p.121)
}

Isso nos permite concluir que participar não é somente uma questão de escolha individual, mas sim uma questão de expansão de oportunidades. $\mathrm{O}$ fato é que os mais pobres e destituídos de recursos políticos provavelmente estarão ausentes das experiências participativas e deliberativas - e, neste caso, o que é necessário não é mais deliberação, mas sim ação de cima para baixo, ou seja, reformas institucionais e a implementação de políticas públicas que tenham como objetivo proteger os interesses e dar maior força à voz dos menos privilegiados (ao menos isso é o que o critério maximin de justiça recomenda).

De acordo com Ian Shapiro, outro problema enfrentado nas democracias contemporâneas diz respeito a preferências e dinheiro: quando minorias abastadas se dispõem a arcar com o custo da comunicação para tornar públicas suas preferências, influenciando cidadãos insuficientemente informados que podem ter uma percepção equivocada sobre as propostas de políticas públicas e seus verdadeiros interesses. Some-se a isso o problema da questão do financiamento político que, quando exercido com 
distorções, tem a tendência a produzir vínculos entre doador e beneficiado, fazendo com que haja um desequilíbrio na representação, a medida em que os interesses dos financiadores passam a ter maior peso na decisão dos políticos do que os interesses do eleitorado em geral (VITA, 2003, pp.118-122).

De acordo com Vita (2003, p.124), Robert A. Dahl aponta duas categorias de distribuição desigual de recursos políticos cruciais: as desigualdades de recursos, oportunidades e posição econômica e as desigualdades de conhecimento, informação e recursos cognitivos. Rawls vai nesta mesma direção ao afirmar que

\begin{abstract}
"Níveis elevados de pobreza e desigualdade e uma excessiva concentração da riqueza e da propriedade degradam o valor que as liberdades políticas têm para os mais desfavorecidos e permitem que os mais favorecidos, porque mais capazes de tirar proveito de direitos e oportunidades institucionais que em princípio são iguais para todos, exerçam um peso desproporcional sobre os termos da discussão pública e sobre as decisões políticas" (VITA, 2003, p.125)
\end{abstract}

Reduzir estas desigualdades pode parecer demasiadamente ambicioso, mas não requer outro sistema de governo que não a democracia competitiva. De acordo com John Rawls o que precisamos, neste caso, é garantir o valor eqüitativo das liberdades políticas para que os resultados do processo democrático sejam mais justos, e ele sugere dois arranjos institucionais para lidar com este problema: o imposto sobre heranças e doações, com o objetivo de corrigir de maneira gradual e constante a concentração de riqueza e a adoção do financiamento público exclusivo, além do estabelecimento de limites às contribuições de pessoas físicas e jurídicas, bem como o controle dos gastos de campanha (VITA, 2003, p.125). Com isso o objetivo seria erguer barreiras entre o poder econômico e o poder político, havendo muito espaço para pesquisas teóricas e empíricas que visem 
estabelecer quais arranjos institucionais poderiam ser eficazes para que este objetivo se estabeleça.

Para que possamos compreender melhor em que sentido a democracia representativa em vigor pode ser aprimorada, é importante que observemos qual é o ideal de democracia de devemos buscar e, também, se o ideal de igualdade política pode, de fato, ser alcançado nos sistemas democráticos.

Em Democracy and its critics (1989), Dahl trata da questão da representação de uma maneira bastante semelhante à de Bernard Manin $(1995,1997)$, e faz menção a um diálogo hipotético travado entre Jean-Jacques Rousseau e James Madison (DAHL, 1989, p.225). Neste diálogo ambos concordam que um governo na escala de um país não pode ser realmente democrático, pois a idéia de democracia envolve a participação direta dos cidadãos - não somente na confecção das leis, como também na sua administração - , o que não seria possível em tal configuração territorial. Eis que Madison defende a representação em democracias de larga escala. Para Rousseau a representação não solucionaria o problema central da participação, porém, Madison observa muito bem que, mesmo em democracias de pequena escala apenas uma pequena parcela das pessoas efetivamente fala, a maioria limita-se a ouvir, pensar e votar, o que é perfeitamente cabível numa democracia representativa, não sendo necessária a democracia direta para isso. Ele afirma que, se todas as instituições da poliarquia são essenciais para o processo democrático de grandes sistemas, então o governo desses grandes sistemas seriam poliarquias, e mais: afirma que, se os grandes sistemas não podem ser perfeitamente democráticos, é melhor que sejam democráticos da maneira possível do que sejam não-democráticos e, neste caso, a melhor alternativa seria a poliarquia. Robert A. Dahl define o que vem a ser poliarquia em seu livro Poliarquia (2005). 
Neste trabalho Dahl reserva o termo "democracia" para designar um sistema político que tenha como uma de suas características principais o fato de ser inteiramente, ou quase inteiramente, responsivo a todos os seus cidadãos, considerados politicamente iguais (Dahl, 2005, p.25). Três seriam as condições necessárias (ainda que não suficientes) à democracia. Numa democracia, todos os cidadãos plenos devem ter oportunidades plenas:

1. De formular suas preferências.

2. De expressar suas preferências a seus concidadãos e ao governo através da ação individual e da coletiva.

3. De ter suas preferências igualmente consideradas na conduta do governo, ou seja, consideradas sem discriminação decorrente do conteúdo ou da fonte da preferência. (DAHL, 2005, p.26)

Para que essas três oportunidades possam existir para um grande número de pessoas (situação dos atuais Estados-nação), faz-se necessário que as instituições da sociedade forneçam pelo menos oito garantias, quais sejam:

1. Liberdade de formar e aderir a organizações.

2. Liberdade de expressão.

3. Direito de voto.

4. Elegibilidade para cargos públicos.

5. Direito de líderes políticos disputarem apoio.

5a. Direto de líderes políticos disputarem votos.

6. Fontes alternativas de informação.

7. Eleições livres e idôneas.

8. Instituições para fazer com que as políticas governamentais dependam de eleições e de outras manifestações de preferência. (DAHL, 2005, p.27)

Estas oito condições especificam uma noção mínima, empírica e operacional de democracia, que Dahl prefere denominar poliarquia, e que se presta a diferenciar os regimes democráticos existentes de diferentes modalidades de regime autocrático (ou nãodemocrátrico). 
Dahl considera que a democratização seria formada por pelo menos duas dimensões, quais sejam: competição política e a inclusão. Quando colocadas em dois eixos $\mathrm{x}$ e $\mathrm{y}$, em que o encontro de ambos signifique nenhuma competição política e nenhuma inclusão e suas extremidades indiquem a tendência à presença plena de ambas as dimensões numa sociedade, podemos avaliar o quanto um regime está próximo ou distante de ser considerado uma poliarquia:

a) regimes que se encontram próximos ao encontro de ambos os eixos, ou seja, que possuem nenhuma ou quase nenhuma competição política e nenhuma ou quase nenhuma inclusão, serão chamados de "Hegemonias fechadas";

b) regimes que se encontram na extremidade do eixo da competição política serão chamados de "Oligarquias competitivas". Nesses regimes, apesar de não haver nenhuma, ou quase nenhuma inclusão, há competição;

c) regimes que se encontram na extremidade do eixo da inclusão serão chamados de "Hegemonias inclusivas". Nesses regimes, apesar de não haver ou quase não haver competição, há maior direito de participação;

d) regimes que se encontram na extremidade oposta ao encontro dos eixos (onde se encontram as Hegemonias fechadas) serão chamados de "Poliarquias". Nesses regimes há ampliada competição e amplo direito à participação. Aqui poderia estar o que chamamos de "democracia" mas, como na concepção de Dahl, a democracia pode envolver mais dimensões do que as duas apresentadas neste esquema e pelo fato de o autor não 
considerar nenhum sistema do mundo real como sendo plenamente democratizado, o nome dado a estes regimes será "poliarquia".

Dahl optou por chamar os regimes que se encontram na extremidade oposta ao encontro dos eixos de poliarquia ao invés de democracia pelo fato de considerar que nenhum grande sistema do mundo real é plenamente democratizado, logo, o termo democracia deveria ser reservado para o ideal teórico e os sistemas mundiais reais que mais se aproximam deste ideal deveriam ser chamados de poliarquia. De acordo com Dahl,

\begin{abstract}
As poliarquias podem ser pensadas como regimes relativamente (mas incompletamente) democratizados, ou, em outros termos, as poliarquias são regimes que foram substancialmente popularizados e liberalizados, isto é, fortemente inclusivos e amplamente abertos à competição política. (DAHL, 2005, p.31)
\end{abstract}

Em seu trabalho On political equality, de 2006, Robert A. Dahl trata da igualdade política. Dahl observa que nos países democráticos contemporâneos a lacuna entre o objetivo da igualdade política e a realidade de seu atual alcance é grande. Assumindo-se que o ideal democrático pressupõe que a igualdade política seja desejável e, como a democracia é vista como um objetivo ou ideal, então a igualdade política também deve ser vista como um objetivo ou ideal. Partindo-se da idéia do julgamento moral segundo o qual todos os seres humanos são iguais, não sendo nenhum ser humano intrinsecamente superior aos demais, e que o bem ou os interesses de cada pessoa devem ser levados em igual consideração, podemos afirmar que, dentre seres humanos adultos, nenhum indivíduo é tão 
melhor qualificado do que os demais para governar com autoridade completa. Deste modo, concluímos que a igualdade política, além de desejável, é um objetivo cuja perseguição é razoável e, a partir daí, passamos a um outro questionamento: de que maneira podemos chegar a este ideal? Que instituições políticas são necessárias para que um sistema político possa ser identificado como sendo democrático? E por qual motivo são estas as instituições necessárias? (DAHL, 2006, p.6) Para que estes questionamentos possam ser satisfatoriamente respondidos devemos ter em mente uma concepção de ideal democrático que nos permita definir um modelo em relação ao qual possamos comparar os vários sistemas atualmente existentes. De acordo com Dahl (2006, pp.9-10), um ideal mínimo de democracia possuiria as seguintes características: participação efetiva (effective participation) - antes que uma política seja adotada, todos os membros do demos devem ter oportunidades iguais e efetivas de levar ao conhecimento dos demais membros sua visão a respeito de tal política; igualdade de voto (equality in voting) - todos os membros do demos devem gozar de oportunidade iguais e efetivas de voto, e todos os votos devem ter o mesmo peso (princípio democrático de "um eleitor, um voto"; beneficiar-se de ganho de conhecimento (gaining enlightened understanding) - todos os membros do demos devem gozar de oportunidades iguais e efetivas de aprender sobre todas as alternativas relevantes de políticas e suas consequiências; controle final da agenda política (final control of the agenda) - o demos deve gozar da oportunidade exclusiva de decidir como (e se) seus membros escolherão os temas que farão parte da agenda política; inclusão (inclusion) - a todos os membros do demos deve ser garantido o direito de tomar parte nos quatro pontos previamente citados; e direitos fundamentais (fundamental rights) ${ }^{31}$ - cada uma das

\footnotetext{
${ }^{31}$ Dahl observa que os direitos necessários à democracia não podem ser legitimamente infringidos pela maioria: a imposição de limites à autoridade da maioria, quando esta visa à adição de ações que destruirão
} 
características necessárias a um ideal democrático prescreve um direito que constitui uma parte necessária do ideal democrático: o direito de participação, o direito de voto igual, o direito de buscar conhecimento necessário para que compreenda os assuntos da agenda política e o direito de participar em pé de igualdade com os demais membros do demos no exercício de controle final da agenda. A democracia não consiste apenas num processo político: faz-se necessário também um sistema de direitos fundamentais.

Tendo em mente essas características podemos, então, afirmar que existe alguma democracia ideal em vigor hoje no mundo? Apesar de as instituições políticas das democracias contemporâneas serem necessárias para que um sistema político possa alcançar um nível relativamente alto de democratização, eles não podem ser - e talvez nunca sejam - suficientes para que se alcance o ideal democrático (DAHL, 2006, p.10). Relembrando a reflexão de Manin acerca da democracia direta, Dahl observa que muitos defensores da democracia direta afirmam que o próprio termo democracia representativa é contraditório, pois uma democracia não pode ser representativa. Porém, esta visão tem falhado em conquistar adeptos.

Dahl (2006, p.12) afirma que, analisando a Europa e países de língua inglesa nos séculos XIX e XX, observamos uma série de instituições necessárias ao funcionamento da democracia representativa. É importante observar que estas instituições são praticamente idênticas às oito instituições anteriormente citadas por Dahl para que as três oportunidades que devem existir numa democracia possam se verificar para um grande número de pessoas.

Apesar das diferenças na estrutura constitucional de cada país, uma série de instituições políticas básicas podem ser verificadas em todos estes países, quais sejam:

instituições como, por exemplo, a liberdade de expressão, não é inconsistente com os princípios democráticos. 
1. Todas as políticas e decisões governamentais importantes são direta ou indiretamente tomadas por oficiais eleitos pelo povo, via eleições populares, para exercerem tal função.

2. Os cidadãos participam livremente em eleições justas e freqüentes, nas quais a coerção é incomum.

3. Os cidadãos são aptos a concorrer e votar nas eleições, desde que correspondam à exigências de idade e residência.

4. Aos cidadãos deve ser permitido que expressem suas opiniões acerca de assuntos políticos relevantes publicamente sem que sejam alvo de punições por conta disso.

5. Todos os cidadãos têm a liberdade de buscar fontes independentes de informação junto a outros cidadãos, jornais e muitas outras fontes. Além disso, fontes de informação que não se encontram sob o controle do governo ou de qualquer outro grupo existem e são protegidas pela lei.

6. Em contraste com a visão que dominava nas democracias antigas e repúblicas, de que "facções" políticas eram um perigo a ser evitado, atualmente teoria e prática têm caminhado rumo à afirmação de que os cidadãos poderão alcançar seus direitos somente se puderem exercer o direito prévio de formar e participar de associações e organizações independentes, dentre elas partidos políticos e grupos de interesse.

Estas seriam, então, sob o ponto de vista de Dahl, as instituições necessárias para que se alcance um nível satisfatório de democracia numa unidade política, como um país, que seja muito grande para que se adote a assembléia democrática. É importante observar que estes pontos coincidem com as garantias que devem estar presentes para que possam se 
verificar as três oportunidades necessárias ao processo democrático. Estes pontos não são incompatíveis com os levantados por Bernard Manin. Podemos dizer que os quatro princípios apontados por Manin e estas seis instituições políticas apontadas por Dahl são, na verdade, complementares, quando não correspondentes.

As eleições, evidentemente, são apontadas por ambos como algo substancial para a democracia representativa. Como já observamos anteriormente, é a eleição que, através do consentimento dos governados em relação aos governantes, legitima a representação neste tipo de governo. Outro ponto de encontro situa-se na liberdade de opinião, no que se refere ao acesso à informações e expressão da opinião pública. No governo democrático representativo os cidadãos devem ser livres para buscarem informações onde desejarem e para expressarem suas opiniões políticas sem sofrerem coerção. Estes valores, que devem ser garantidos, correspondem às liberdades básicas abarcadas pelo primeiro princípio de justiça de John Rawls.

Até este ponto concluímos que a igualdade política é um objetivo altamente desejável e que este objetivo é mais passível de se concretizar num sistema político democrático. Logo, nos resta a seguinte questão: a igualdade política é um objetivo realmente alcançável, mesmo num sistema democrático? Em outras palavras, mesmo que o sistema político em vigor seja aquele considerado o mais adequado à realização do objetivo da igualdade política - a democracia representativa - , é possível que existam alguns aspectos da natureza humana e da sociedade humana que possam vir a representar uma barreira à concretização deste ideal, a ponto deste objetivo tornar-se tão inalcançável que deveríamos abandonar quaisquer esforços no sentido de alcançá-lo? Dahl (2006, p.18) nos apresenta o exemplo da escravidão nos Estados Unidos para ilustrar o quão distantes estão a retórica e a realidade a respeito da igualdade política. Os autores da Declaração da 
Independência dos Estados Unidos da América não fizeram menção, no documento, aos escravos e aos indivíduos livres de origem africana, apesar destes constituírem uma fração substancial da população americana. Para que a escravidão pudesse ser abolida foi necessário lançar mão da força das armas e de emenda constitucional, e foi preciso mais um século para que os direitos políticos dos afro-americanos fossem efetivamente reconhecidos no Sul dos Estados Unidos. Ainda hoje as heranças negativas da escravidão são sentidas nos Estados Unidos, no que se refere à igualdade humana, à dignidade, à liberdade e ao respeito. Neste sentido, a eleição de Barack Obama para a Presidência da República (20092013) figura como um importante passo no processo de cicatrização das profundas marcas que a escravidão deixou naquela nação.

A lacuna existente entre retórica e prática no que se refere à igualdade política é identificada, também, em outros países democráticos, onde uma grande parte dos homens adultos estavam excluídos do direito de voto até o final do século XIX, e até mesmo começo do século XX. Porém, se levarmos em conta o fato de que em 1900 existiam 48 países independentes ou moderadamente independentes, e que destes apenas oito possuíam todas as instituições básicas de uma democracia representativa, sendo que em apenas um deles (Nova Zelândia) as mulheres possuíam direito de voto, e que estes oito países juntos não abarcavam mais de 12 por cento da população mundial; e que no ano 2000, dentre 190 países, 85 possuíam instituições e práticas próprias da democracia representativa, incluindo o sufrágio universal, sendo que estes países abarcam cerda de $60 \%$ da população mundial, observamos um avanço significativo na expansão da democracia e dos direitos políticos.

Este avanço se deu através da ação, tanto dos mais privilegiados quanto dos menos privilegiados. No que se refere aos membros mais privilegiados dentro destes países - elites política, social e econômica - Dahl afirma que sua superioridade era normalmente 
embasada por doutrinas religiosas e filosóficas. Os membros da elite acreditavam que estas doutrinas eram aceitas entre os que membros dos grupos subordinados, porém, é interessante observar que, na realidade, estes não pareciam aceitar tão bem estas doutrinas e, muitas vezes, atribuíam a posição inferior por eles ocupadas à injustiça. Eis que, estimulados por novas oportunidades, como a mudança de condições através de idéias, crenças, estruturas e gerações, e motivados por sentimentos como raiva, ressentimento, senso de justiça e lealdade ao grupo, os membros dos grupos subordinados passaram a exercer pressão por mudança, pelos mais diversos meios, apoiados, também, por membros da elite, motivados por convicção moral, compaixão, oportunismo, medo das conseqüências da desordem, etc. Esta pressão acabou desembocando em significativos ganhos de poder, influência, status, educação e renda, através de meios violentos e revolucionários ou de mudanças graduais (DAHL, 2006, pp.27-28). Mas o que leva os indivíduos a agirem de uma maneira que desencadeará mudanças no sentido de fortalecer a igualdade política? Dahl acredita que o que motiva a busca por eqüidade não é apenas a razão pura, mas as emoções e paixões. Nisso as idéias de Dahl identificam-se mais com as de Rawls do que com as de Kant; enquanto para este a razão é a única parte da natureza humana que nos impele à ação moral, para aquele o objetivo da igualdade política é justificada pela razão, amparada pela capacidade moral de julgamento derivada da experiência e, talvez, por aspectos básicos da natureza humana. Sendo assim, Rawls nos oferece um forte argumento a favor da liberdade política ( $1^{\circ}$ princípio da justiça), baseado numa visão muito mais realista da natureza humana ${ }^{32}$ (DAHL, 2006, p.36). Porém, estes ganhos no sentido da ampliação e consolidação da igualdade política não se manteriam, se não fosse por alguns

\footnotetext{
${ }^{32}$ Dahl (2006, p.40) cita o neurologista Antonio Damásio, que afirma que as razões não podem ser separadas das emoções e dos sentimentos, nem do aprendizado e da experiência.
} 
aspectos da natureza humana que nos distinguem de todos os outros seres vivos: nossa incrível capacidade de cooperação que nos habilita a criar organizações com um grau de complexidade que nenhuma outra espécie seria capaz. Além disso, os seres humanos são capazes de criar instituições que se perpetuam através de hábitos, comportamentos e crenças, garantindo, assim, que os ganhos obtidos sejam passados de geração para geração, quase sem alterações.

Porém, os ganhos que parecem ser enormes sob uma perspectiva histórica, parecem ser extremamente modestos quando comparados ao padrão ideal (DAHL, 2006, p.50) e, dentre as barreiras encontradas para que a igualdade política se verifique, Dahl enumera as seguintes: a distribuição de recursos políticos, habilidades e incentivos (the distribuition of political resources, skills, and incentives); os limites de tempo disponível para dedicar-se à política (irreducible limits on time); o tamanho dos sistemas políticos (the size of political systems); a prevalência das economias de mercado (the prevalence of market economies); a existência de sistemas internacionais importantes, mas não democráticos (the existence of international systems that may be important, but are not democratic); e a inevitabilidade de crises severas (the inevitability of severes crises).

Robert Dahl analisa o caso americano para tentar responder à seguinte pergunta: a desigualdade política nos Estados irá aumentar ou irá se aproximar do ideal? Apesar de sua visão ser pessimista, o autor trata da possibilidade de que uma grande, porém não improvável, mudança na cultura e valores americanos, possa fazer o ideal de igualdade política ser um objetivo mais próximo. As reformas apontadas por Dahl (2006, pp.100-103) pertencem a dois grupos: (1) reformas que tratam diretamente da igualdade política reforma do financiamento de campanhas (campaign finance reform) e reforma eleitoral (electoral reform); (2) reformas que tratam indiretamente da igualdade política (através do 
aumento da igualdade econômica e social) - reforma distrital (redistricting reform) e seguro-saúde universal (universal health care coverage); programas que ampliem as economias (normalmente ligadas á aposentadoria) dos mais pobres (programs to enhance savings among the poor); aumentar o salário mínimo (raise minimum wage), aumentar o EITC (increase the Earned Income Tax Credit), e expandir os subsídios para os cuidados com a infância (expand child care subsidies); tornar o ensino superior possível para mais pessoas (make higher education acessible to more people).

Nesta dissertação tratarei das reformas do primeiro grupo, que são aquelas que procuram aumentar a igualdade política de maneira direta e, dentre as duas reformas propostas, trabalharei a primeira: reforma do financiamento de campanhas, no sentido de estabelecer limites às doações, com o intuito de impedir que os doadores se aproveitem de sua posição economicamente privilegiada para influenciar os políticos. É importante ressaltar que, neste caso, Dahl aponta esta reforma como sendo importante nos Estados Unidos, que é uma democracia consolidada e um país considerado desenvolvido, o que nos mostra que os perigos inerentes à prática do financiamento político efetivamente não estão restritos aos países subdesenvolvidos. Dentro da questão do financiamento político, dentre as condições necessárias (ainda que não suficientes) à democracia, trato da terceira condição (ter suas preferências igualmente consideradas na conduta do governo, ou seja, consideradas sem discriminação decorrente do conteúdo ou da fonte da preferência) e, dentre as garantias que as instituições da sociedade devem fornecer para que as condições necessárias à democracia se verifiquem, trato, da oitava garantia (instituições para fazer com que as políticas governamentais dependam de eleições e de outras manifestações de preferência), ambas ligadas ao valor eqüitativo das liberdades políticas. 
As desigualdades oriundas de um financiamento político não ideal, que favoreça àqueles que possuem maior poder aquisitivo, fere de maneira decisiva esta condição, e o que pretendo verificar nesta dissertação é qual seria a melhor configuração do financiamento de partidos políticos e campanhas eleitorais para que o valor eqüitativo das liberdades políticas possa se verificar. 


\section{Capítulo 3: O financiamento de partidos políticos e campanhas eleitorais}

As democracias modernas deparam-se cada vez mais com o desafio de conciliar o financiamento de partidos políticos e campanhas eleitorais com o respeito aos valores básicos de democracia e justiça. Dentre as questões problemáticas está a de assegurar "a igualdade dos cidadãos na decisão eleitoral, a liberdade de eleição dos eleitores, a independência dos representantes em relação a pressões externas e seu compromisso com o bem comum" (SPECK, 2004a, p.1; 2003a, p.1). O financiamento político ${ }^{33}$, tão necessário para que a democracia representativa se verifique de maneira satisfatória, pode colocar estes valores democráticos em risco, caso o dinheiro tenha valor decisivo no processo eleitoral, acabando com o princípio básico de "um cidadão, um voto" - aqueles com maior poder aquisitivo e, conseqüentemente, maior capacidade de contribuir com altos valores terão seus interesses levados em conta com maior freqüência e/ou preferência por parte dos governantes - e se os candidatos e eleitos dependerem de seus financiadores, a autonomia no exercício do mandato estará ameaçada. Se o dinheiro for utilizado pelo candidato para comprar votos, a liberdade de escolha do eleitor será ameaçada. (SPECK, 2003a, p.1).

O financiamento político - uma das estratégias utilizadas pelos grupos de interesse e lobistas para fazerem valer seus interesses - apesar de necessário, pode trazer sérios riscos ao valor eqüitativo das liberdades políticas, desviando-se, muitas vezes, para o terreno da

\footnotetext{
${ }^{33}$ O termo "financiamento político" engloba tanto o financiamento de partidos políticos quanto o financiamento de campanhas eleitorais. Isso se dá pelo fato de as linhas entre um e outro serem demasiadamente tênues, confundindo-se em muitos países.
} 
corrupção. De acordo com Zovatto, dentre as principais manifestações vinculadas à relação

entre financiamento político e corrupção, podemos destacar as seguintes:

a recepção de contribuições que infringem as regulamentações existentes; o uso para fins partidários ou eleitorais de dinheiro derivado de atividades corruptas; o uso indevido de recursos do Estado com fins político-partidários ou proselitismo, inclusive o desvio de serviços e tempo dos funcionários públicos; suborno antecipado: a aceitação de dinheiro de pessoas ou empresas em troca de promessas ou favores ilícitos em caso de ascensão a postos públicos; suborno: pagamentos a funcionários por parte de fornecedores do Estado em retribuição por favores recebidos; a aceitação de contribuições de fontes questionáveis; participação e favorecimento de negócios ilícitos (tóxicos, armas, jogo, prostituição, etc); utilização de dinheiro com fins proibidos, como por exemplo, "compra" de votos. (ZOVATTO, 2005, p.290)

Ainda de acordo com Zovatto (baseado em Jorge Malem), a corrupção política traz inúmeros efeitos negativos para o sistema democrático:

\begin{abstract}
a corrupção solapa a regra da maioria que é própria da democracia; corrói os fundamentos da moderna teoria da representação que está na base do ideal democrático, afeta o princípio de publicidade e transparência; empobrece a qualidade da democracia ao subtrair da agenda pública todas aquelas questões que constituem a contraprestação corrupta correspondente à recepção por parte dos partidos de fundos irregulares; e provoca uma série de ilícitos em cascata, isto é, os dirigentes políticos, para dissimular os fundos obtidos irregularmente, se vêem jogados numa espécie de lei de Gresham, em que são obrigados a realizar ações incorretas ou indevidas para evitar ações ou conseqüências ainda piores, com a deterioração que isso implica para a vida cidadã. (ZOVATTO, 2005, p.291)
\end{abstract}

Esta complicada relação entre dinheiro e política é um dos motivos pelos quais o tema vem sendo tão debatido no meio acadêmico e na sociedade em todo o mundo. Como fazer com quem o financiamento de partidos políticos e campanhas eleitorais seja mais transparente, livre de corrupção e, conseqüentemente, mais justo? Esta é a questão crucial. 


\subsection{A influência dos grupos de interesse}

No que se refere à influência do lobby dos grupos de interesse e, dentre suas estratégias, o financiamento de partidos políticos e campanhas eleitorais, podemos encontrar semelhantes formas de encarar a questão na bibliografia que trata do tema.

Em seu artigo, Smith (1995) faz uma revisão crítica das pesquisas publicadas nas décadas de 1980 e 1990 sobre o Congresso americano, apontando para o fato de que questões acerca das metodologias empregadas nas pesquisas realizadas no período deixam dúvidas em relação a muitas das conclusões às quais elas chegaram e, juntas, apresentam resultados variados ${ }^{34}$. Ao longo das duas décadas anteriores ao artigo, a preocupação de jornalistas e outros observadores em relação ao assunto havia aumentado imensamente, apontando para a super-representação de grupos de interesse em detrimento dos grupos não-organizados. No entanto, os argumentos utilizados para basear este argumento são falhos: são evidências esparsas, entrevistas com lobistas e membros do Congresso e correlações feitas por estudos que não comprovam uma ligação convincente entre contribuições de campanha de grupos de interesse e decisões tomadas pelos membros do Congresso $^{35}$. Na verdade, quando tomados em conjunto, estes estudos parecem mais apontar para uma situação na qual as contribuições têm menos influência no processo do que se imagina, apesar dos problemas de metodologia apresentados e da inadequação dos dados, que dificultam qualquer tipo de afirmação mais contundente. Se considerarmos as pesquisas acadêmicas sobre o tema, encontraremos resultados conflitantes: por um lado temos as pesquisas que demonstram que não há correlação entre as contribuições de

\footnotetext{
${ }^{34}$ Estes resultados mistos também são observados por Potters e Sloof (1995).

${ }^{35}$ Análise neste sentido também pode ser encontrada em Potters e Sloof (1995, p. 404).
} 
campanha e a tomada de decisão no Congresso; por outro lado temos as pesquisas que demonstram forte relação entre as contribuições de campanha e a tomada de decisão no Congresso e, por fim, temos as pesquisas que apresentam resultados mistos ${ }^{36}$.

Mas de que maneira podemos dizer que estes resultados fazem algum sentido? Para procurar responder a esta questão, Smith (1995, p.93-97) nos aponta quatro caminhos:

(a) O propósito das contribuições de campanha é comprar acesso aos políticos, e não votos. De acordo com Langbein $(1986)^{37}$, também citada no artigo de Smith, os resultados de sua análise sugerem, mas não provam, que o dinheiro, de fato, compra acesso. Salisbury afirma que os grupos de interesse estão virtualmente bem servidos no que se refere ao acesso mas, freqüentemente, estão subordinados no grau de influência que conseguem exercer sobre os políticos para os quais contribuem (SMITH, 1995).

(b) Os grupos de interesse têm pouca, se é que têm alguma, influência nas decisões tomadas pelos políticos, exceto sob certas condições, relacionadas ao alcance da questão. As contribuições teriam muito mais influência nas decisões políticas quando uma das seguintes condições estiverem presentes: quando se trata de assuntos de baixa visibilidade; quando o assunto é especializado ou técnico; quando os benefícios resultantes estão concentrados e os custos distribuídos dentre os eleitores, quando o assunto for apartidário e não ideológico; quando o público estiver indiferente ou ignorar o assunto em questão; quando o assunto que interessar a um determinado grupo não for do interesse de nenhum

\footnotetext{
${ }^{36}$ Alguns estudos apontam que a influência das contribuições de campanha de grupos de interesse variam de acordo com cada assunto, outros estudos apontam que estas contribuições estão relacionadas com votos congressionais em algumas questões, mas não em outras, outros que a influência varia dentro do Senado de acordo com a proximidade das eleições e, por fim há ainda estudos que concluem que contribuições podem influenciar em alguns anos eleitorais, mas não em outros, etc. (SMITH, 1995, p.92).

${ }^{37}$ Neste texto Laura Langbein (1986) analisa o número de minutos gastos pelos políticos (92 congressistas) com os representantes de grupos de interesses em seus escritórios.
} 
outro grupo, ou quando os grupos de interesse que tiverem contribuído também praticarem intenso lobby no que se refere ao assunto em questão; etc.

(c) Uma terceira resposta aos achados conflitantes está em argumentar, com base em Conway (1991), Sorauf (1992) e Denzau e Munger (1986), que as contribuições de grupos de interesse geralmente têm pouca influência nas decisões de base da Câmara e do Senado, e que essa influência limita-se aos níveis menos visíveis do processo legislativo e aos estágios anteriores ao processo legislativo.

(d) Conclusões sobre a influência das contribuições de grupos de interesse são prematuras, uma vez que a presença de resultados conflitantes nos estudos sobre o tema deve ser interpretada mais como sendo um artefato de falhas metodológicas do que reflexo de haver ou não influência de fato. Deste modo, pode ser que as contribuições de grupos de interesse tenham, de fato, influência e esta não seja detectada devido às deficiências da metodologia, como também pode ser que tais contribuições não tenham nenhuma influência e isto não seja detectado devido às falhas metodológicas.

Com base no artigo de Smith podemos concluir que há necessidade de muitas outras pesquisas sobre o tema, atentando sempre para a dificuldade de se encontrar resultados conclusivos devido, sobretudo, às questões metodológicas.

De acordo com Potters e Sloof (1995), e indo ao encontro da análise de Smith, existe ampla evidência de que os grupos de interesse afetam o processo de decisão política, sendo a variação nos resultados da contribuição um efeito das diferentes estratégias de contribuição adotadas pelos grupos de interesse. São dois os grandes modelos de estratégia de contribuição por parte dos grupos de interesse apontados por Potters e Sloof (1995, p.410): 
- o modelo de troca (service-induced or exchange model), no qual os grupos de interesse procuram aproximar-se e influenciar candidatos fortes, seguros, mas que estão ainda indecisos em relação ao assunto em questão ou que não são alinhados com as preferências de nenhum grupo de interesse específico;

- e o modelo de apoio (position-induced or support model), no qual os grupos de interesse optam por dar suporte e fazer doações para os "amigos", ou seja, candidatos cujas idéias correspondam às do grupo de interesse em questão.

Potters e Sloof (1995, p.404) analisaram estudos que utilizavam dados quantitativos e modelos empíricos e que explicitamente relacionavam variáveis de grupos de interesse com variáveis de políticas públicas para responder como e quando grupos de interesse influenciam políticas públicas. Através desta análise os autores chegam a alguns fatos que em muito se aproximam da análise realizada por Smith, quais sejam:

1) as contribuições de campanha e o lobby afetam o voto dos legisladores, sobretudo em assuntos que têm baixa visibilidade pública;

2) A estratégia dos grupos de interesse são conduzidas de modo a apoiar legisladores cujas idéias vão ao encontro das idéias compartilhadas pelo grupo de interesse em questão;

3) quanto mais organizados forem os membros de um grupo de interesse, maior será sua influência política;

4) o interesse de um grupo em influenciar políticas públicas é um determinante positivo de sua atividade política e de seu sucesso; 
5) há uma relação intrínseca entre o número de participantes potenciais de uma ação coletiva e a influência nos resultados das políticas, devido aos efeitos do free riding e aos efeitos dos recursos eleitorais do grupo - o mesmo serve para medidas de concentração;

6) a presença de uma força opositora pode prejudicar a argumentação de um grupo de interesse na política e

7) fortes pressões eleitorais na sociedade politicamente organizada e a presença de um eleitorado bem informado reduzem a influência de grupos de interesse, sobretudo quando os políticos precisam de apoio eleitoral.

É importante destacar que, independentemente da influência de grupos de interesse, os valores e as crenças dos membros do Congresso são relativamente estáveis a curto prazo, mas suas conexões com as propostas legislativas não. Crenças e propostas estão atreladas, dependendo da percepção dos congressistas quanto às conseqüências da proposta, e os lobistas podem influenciar esta percepção, afetando o resultado do Legislativo. Os grupos de interesse podem afetar a percepção acerca de dada proposta em duas direções: tanto junto aos políticos, no que se refere à percepção do público sobre determinada proposta, quanto junto ao público no que se refere à sua percepção quanto aos benefícios que determinada proposta poderá lhe trazer. Normalmente esta interferência se dá através do processo deliberativo. 
Esta questão foi levantada por Susan Stokes em seu texto de 1998, "Pathologies of Deliberation", no qual ela analisa os resultados perversos da deliberação ${ }^{38}$ por meio da influência da comunicação pública nas preferências e identidades dos cidadãos em questões democráticas, da influência das preferências dos cidadãos na política de governo, e da influência dos grupos de interesse e da imprensa na formação da opinião. A deliberação e a troca de informações podem abrir espaço para a manipulação de crenças e preferências.

Existem, de acordo com Stokes, cinco "seqüências" de acontecimentos envolvendo influência, informação e política:

- A primeira seqüência é aquela que retrata o pensamento encontrado na teoria clássica da democracia no qual preferências dos cidadãos influenciam as propostas dos políticos chegando a determinada política.

- A segunda seqüência mostra o debate da elite gerando opinião pública e chegando a determinada política. Aqui podem ser gerados dois desvios, quais sejam, atores privados, baseados em seu auto-interesse, intervêm no debate com a intenção de levar o público a constituir julgamentos errôneos sobre efeitos que seriam causados por determinada política; e políticos agindo com base em percepções errôneas das preferências dos eleitores: são as pseudo-preferências, que muitas vezes foram manufaturadas pela ação de lobistas.

- A terceira seqüência inicia-se com interesses especiais comunicando contra a política "A", fazendo com que os cidadãos posicionem-se contra a política

\footnotetext{
${ }^{38}$ Por deliberação aqui, entenda-se a definição fornecida por Adam Przeworski em seu texto "Deliberation and Ideological Domination": "deliberação é uma forma de discussão que tem a intenção de mudar as preferências com base nas quais as pessoas decidem como agir” (1998, p.140).
} 
"A" e a política "A" acabe por fracassar. Este é o caso do financiamento do sistema de saúde nos EUA na década de 50. Na administração de Harry Truman a American Medical Association (AMA) desarmou os esforços dos Democratas para criar um fundo de seguro-saúde. A AMA gastou cerca de 1 milhão de dólares em propagandas que procuravam convencer a população de que o fundo reduziria a qualidade dos cuidados médicos e, também, a escolha do paciente. Os esforços da AMA surtiram efeito, pois os legisladores assumiram que os eleitores deveriam ser contrários a qualquer seguro-saúde e que deviam evitar entrar em qualquer tipo de confronto contra a AMA. Assim, em 1952 o seguro-saúde estava fora da agenda política do governo.

- A quarta seqüencia inicia-se com interesses especiais comunicando contra a política "A", fazendo com que os políticos tenham a percepção errônea de que o público está contra a política "A" e a política "A" acabe por fracassar. Este foi o caso da reforma do financiamento de saúde proposta pelo governo Clinton nos EUA na década de 1990, quando a propaganda contra a proposta teve grande influência. Na campanha presidencial de 1992 o então candidato Bill Clinton prometeu uma reforma do sistema de saúde. Uma vez eleito, Clinton introduziu seu projeto sobre o assunto, em setembro de 1993 e contou com apoio disperso e relativamente pouca oposição por parte do Partido Republicano no Congresso. Eis que, de maneira similar ao que ocorrera em 1950, a indústria de seguro-saúde introduziu no debate público a idéia de que tal reforma reduziria a qualidade dos serviços e limitaria a escolha dos pacientes, investindo cerca de 60 milhões de dólares em 
propagandas contra a proposta do presidente. Propagandas, estas, que eram veiculadas em locais onde repórteres e editores viviam, para que estas fossem reportadas pela mídia, causando a percepção, dentre os membros do Congresso, de que as mesmas estavam alcançando e persuadindo a opinião dos cidadãos em geral, que estariam, a partir daí, contra a proposta.

- A quinta seqüência tem início com a proposta da política "A" por parte do governo, há oposição e consentimento por parte dos cidadãos, a imprensa divulga oposição pública à política "A”, a oposição acredita no que a imprensa divulga e argumenta contra a política “A”, os cidadãos se opõem à política “A”, a política "A” fracassa.

Na análise desenvolvida por Stokes (1998), podemos perceber a influência de pseudo-preferências e pseudo-identidades, uma vez que a comunicação pública muda não somente preferências como também identidades, sendo capaz, até mesmo, de fazer com que neguemos nossa própria experiência na construção do mundo como o percebemos.

Sendo assim, a deliberação, muitas vezes, apresenta resultados indesejáveis, como a manipulação do que o cidadão comum realmente quer que o governo faça. Para que se cultivem e disseminem os efeitos positivos da deliberação, é preciso que os partidos estejam realmente arraigados na sociedade, levando para o debate político não somente os interesses da elite, mas também do cidadão médio; que a imprensa seja competitiva e consciente da responsabilidade do seu papel na sociedade; que as associações de cidadãos detentoras de menos recursos devam ser capazes de competir em condições de igualdade com as associações de cidadãos detentoras de mais recursos na arena deliberativa; e, por 
fim, que público e políticos saibam de onde vem a informação adquirida, para que possam saber se ela é confiável ou não.

Por fim, a deliberação necessita de dinheiro para ocorrer - pois a disseminação da informação necessita de subsídios para isso -, o que faz com que o dinheiro seja o meio através do qual a dominação ideológica possa se dar.

Além disso, a questão do quanto realmente os grupos de interesse interferem na maneira como os políticos votam carece de mais estudos, com metodologias que propiciem o alcance de resultados mais definitivos. Porém, é importante observar que a compra de influência é muito difícil de se identificar, devido à dificuldade em se comprovar que determinado político agiria de maneira diferente, caso não tivesse recebido determinada doação. Por mais que a observação nos demonstre que existe a relação entre doações de grande somas e a influência política, necessitamos de mais pesquisas com dados conclusivos que apontem na mesma direção para que possamos fazer afirmações mais contundentes. Trata-se, sem dúvidas, de um terreno espinhoso, que necessita de maiores esforços de análise. O que podemos dizer é que "é indispensável que seja o sistema democrático que controle o dinheiro e não o oposto" (ZOVATTO, 2005, p.289). Como chegar a este fim desejado é a questão a ser levantada a partir daqui.

\subsection{O financiamento político no Brasil e na América Latina}

Dentro do amplo leque de estudos sobre o tema do financiamento político, optei por apresentar brevemente características do financiamento de partidos e campanhas e traçar 
um cenário do debate acerca dos modelos de financiamento: público, privado e misto, com pontos positivos e negativos freqüentemente atribuídos a cada uma dessas modalidades. Vou me restringir, na análise que desenvolvo a seguir, aos casos do Brasil e de alguns países da América Latina.

Nos últimos anos, o tema do financiamento de campanhas eleitorais vem ganhando destaque na América Latina, sobretudo por sua associação com escândalos de corrupção e tráfico de influência (ZOVATTO, 2005, p.289). Apesar dos pontos positivos do financiamento político, são seus pontos negativos que vêm gerando debates em todas as democracias do mundo.

Em primeiro lugar, devemos definir o que engloba o financiamento político. $\mathrm{O}$ financiamento político engloba tanto o financiamento de campanhas eleitorais quanto o financiamento de partidos políticos. Ainda que a legislação de muitos países defina o período que deva ser compreendido como período de campanha, é muito difícil delimitá-lo, de fato, na prática. Ações como as pré-campanhas ${ }^{39}$ dentro dos partidos políticos, por exemplo, são uma tendência em várias democracias modernas (SPECK, 2006, p.153).

Para que os partidos políticos possam se manter e para que a competição política possa ser colocada em prática, há a necessidade do dinheiro. A competição por votos não poderia existir se não fossem os recursos materiais para convencer o eleitor, porém, a questão do financiamento político abarca uma série de críticas, decorrentes dos riscos dessa prática. De acordo com Bruno Speck (2003a, p.1; 2006, p.154), podem ser definidas três críticas ao financiamento político, quais sejam:

\footnotetext{
${ }^{39}$ O objetivo das pré-campanhas é definir quem, dentro do partido, será lançado nas eleições como candidato.
} 
1) Crítica “à possível distorção da competição eleitoral pelo peso dos recursos financeiros em campanhas ou pela distribuição desses recursos entre os competidores" (SPECK, 2006, p.154). Para os formuladores desta crítica os montantes crescentes de dinheiro despendidos no financiamento político pode ser interpretado como uma manipulação crescente do eleitorado pelas técnicas de propaganda e comunicação, cada vez mais modernas. Um redução nos valores gastos poderiam ser benéficos para o sistema político. Além disso, o desequilíbrio da competição eleitoral a partir da distribuição de recursos se daria através do poder econômico dos candidatos que autofinanciam suas campanhas, o abuso de recursos do Estado com o objetivo de financiar candidatos ou partidos governistas e o acesso desigual ao financiamento privado. A solução para esta distorção gera controvérsia, pois há uma grande dificuldade em se identificar qual o montante que deveria ser dirigido a cada candidato, uma vez que a própria distribuição eqüitativa dentre eles é raramente defendida, por ser a distribuição desigual um reflexo do grau de enraizamento do partido na sociedade na qual encontram-se inseridos.

2) Crítica "à subversão do princípio da igualdade dos cidadãos quanto à sua influência sobre a representação política" (SPECK, 2006, p.155). Esta crítica diz respeito à quando doações de campanhas podem vir a ferir o princípio democrático de "um eleitor, um voto". Através da doação de montantes elevados, ou do oferecimento de benefícios, como créditos financeiros, descontos em pesquisas, doação de brindes, etc (SPECK, 2006, p.154), indivíduos e/ou grupos podem abrir espaço para influenciar de maneira desigual o processo político. Para impedir que isso ocorra e garantir o princípio de 
igualdade, muitos países incluem em sua legislação o veto à contribuições de determinados atores e o teto para contribuições. Este é o ponto central para o propósito desta dissertação, pois diz respeito, diretamente, ao valor eqüitativo das liberdades políticas.

3) Crítica “à possível dependência dos candidatos eleitos em relação aos seus financiadores, que poderá se expressar na futura concessão de favores, vantagens ou na representação privilegiada de interesses" (SPECK, 2006, p.155). $\mathrm{O}$ ato de doar a campanhas pode gerar uma dependência entre doador e beneficiado, acarretando uma troca de favores futura (compra de acesso ao poder) que, evidentemente, fere os princípios da democracia e da representação, caindo no terreno da corrupção política.

No trabalho de Daniel Zovatto (2005), foram analisados 18 países da América Latina, chegando-se à conclusão de que alguns pontos podem ser encontrados em todos os países estudados, tanto do ponto de vista da formalidade quanto do que se encontra na realidade. Do ponto de vista da formalidade, os seguintes pontos são levantados:

- o predomínio do sistema de financiamento misto, com tendência a favor do financiamento público e da limitação legal do financiamento privado (apesar de, na prática, ser observada uma predominância do financiamento privado na região);

- o financiamento público tem servido mais como aditamento ao financiamento privado, tendo, assim, impacto limitado; 
- a existência de um movimento a favor do controle dos gastos eleitorais, encurtando o tempo de campanha; a regulamentação precária ou inexistente no que se refere ao acesso eqüitativo aos meios de comunicação; os baixos níveis de transparência;

- e, por fim, o ausente ou insuficiente fortalecimento dos órgãos de controle do regime de sanções.

De acordo com Zovatto (citando Karl-Heinz Nassmacher) (2005, p.294), existem quatro maneiras de se regulamentar o financiamento partidário:

(1) com base na autonomia dos partidos - modelo que enfatiza a liberdade e o caráter privado dos partidos, e minimiza a necessidade de regulamentação, confiando nos mecanismos de auto-regulação e auto-correção da competição partidária;

(2) com base na transparência dos recursos financeiros - modelo que enfatiza a importância de os eleitores terem total acesso às informações referentes às finanças partidárias, ficando a cargo deles (os eleitores) fazer uma escolha bem informada no dia da eleição;

(3) com base na vigilância da implementação das regulações sobre o financiamento partidário - modelo que conta com um conjunto de regulamentações detalhadas sobre o financiamento partidário, e sua verificação e implementação é de responsabilidade de uma instituição pública independente e

(4) com base em regulamentação diversificada - modelo que combina supervisão flexível, regulação precisa, incentivos públicos e sanções ocasionais. É o modelo que vigora no Canadá. 
No entanto, segundo Zovatto, os casos por ele estudados da América Latina não se encaixam em nenhum dos quatro modelos apresentados. O que encontramos aqui é

"um sistema que privilegia a regulamentação abundante, baixos níveis de transparência, órgãos de controle débeis, um regime de sanções bastante ineficaz e uma cultura inclinada ao não cumprimento." (ZOVATTO, 2005, p.294)

No caso brasileiro ${ }^{40}$, indo nesta mesma direção, Bruno Speck (2004a, p.14) define a legislação referente ao tema como sendo

relativamente liberal em relação às proibições e os limites impostos à origem dos recursos e aos valores doados, moderada em relação aos subsídios públicos diretos oferecidos à competição política, e avançado em relação à regulação de acesso gratuito aos meios de comunicação e à legislação referente à prestação de contas.

Uma das primeiras formas de financiamento consistia nos recursos do próprio candidato $^{41}$, o que limitava a participação a uma pequena parcela da sociedade economicamente favorecida. Mais tarde, com o surgimento dos partidos, a participação política tornou-se relativamente universalizada, e a arrecadação de recursos passou a se dar junto aos membros do partido. Porém, a insuficiência desses fundos fez com que os partidos recorressem ao financiamento privado por parte de indivíduos ou grupos. Por fim, para amenizar a dependência desse financiamento privado, e por serem os partidos políticos

\footnotetext{
${ }^{40}$ De acordo com Zovatto (2005) no Brasil existe o financiamento público direto (em dinheiro) e indireto, sendo que este inclui o acesso gratuito aos meios de comunicação, o incentivo á divulgação/distribuição de publicações e o uso de edifícios públicos para atividades políticas. Estão proibidos de contribuir os estrangeiros, organizações políticas e sociais, bem como contribuições anônimas. Estão aptos a contribuir Pessoas jurídicas e fornecedores do Estado. As contribuições não podem ser superiores a $2 \%$ do faturamento bruto anual no caso de pessoas jurídicas e $10 \%$ do faturamento bruto anual no caso de pessoas físicas.

${ }^{41}$ Essa forma de financiamento ainda existe em muitos países (SPECK, 2005).
} 
reconhecidos como portadores de um papel fundamental para o bom funcionamento da democracia, foi introduzido o financiamento público, que pode ser direto ou indireto (SPECK, 2005).

\subsection{O financiamento no Brasil - algumas características}

O sistema eleitoral brasileiro fomenta características individualistas na conduta de políticos e candidatos. A apresentação de candidaturas a cargos eletivos é monopólio dos partidos políticos, definido pela Lei Eleitoral, e a idéia de que o apoio partidário possui pouca importância nas campanhas, sobretudo legislativas, é disseminada e baseada em conclusões sem lastro empírico (BRAGA; PRAÇA, 2007, p.182).

Bruno Speck (2003a, p.2) afirma que para candidaturas a cargos executivos existem disputas intrapartidárias, que são resolvidas nas convenções de cada partido; e para candidaturas a cargos legislativos, o autor afirma que a decisão sobre a lista de candidatos é pouco competitiva porque a lista não é ordenada e o número de candidaturas que podem ser apresentadas é muito grande, anulando a necessidade de competição interna e reforçando a característica de competição individual por parte dos candidatos, havendo, também, pouca importância o apoio partidário para as campanhas. Maria do Socorro Braga e Sérgio Praça (2007) nos mostram uma visão um pouco diferente no que se refere à disputa intrapartidária para cargos do legislativo e à importância dos partidos nessa etapa, que possuem poder de seleção e veto às candidaturas, de acordo com normas internas. Em estudo que analisa como se dá a seleção de candidatos à Câmara paulistana, Braga e Sérgio apresentam o processo seletivo interno aos partidos que define quais serão seus candidatos aos cargos 
legislativos. A seleção de candidatos se dá através do cumprimento do que é exigido pela legislação eleitoral e partidária. A legislação eleitoral nacional exige que sejam cumpridos certos requisitos, quais sejam: "nacionalidade; alistamento eleitoral; domicílio eleitoral na circunscrição; estar filiado ao respectivo partido pelo menos um ano antes da data fixada para eleições; idade mínima; e não ter causas penais pendentes" (BRAGA; PRAÇA, 2007, p.191).

Os requisitos impostos pelos partidos somam-se aos impostos pela legislação eleitoral e variam de partido para partido. Analisando as exigências do PP, $\mathrm{PFL}^{42}$, PL, PMDB, PSDB, PSDB, PSB e $\mathrm{PT}^{43}$, podemos observar algumas características: existem requisitos como escolaridade (PP), alinhamento ideológico com o partido (PFL e PSB), participação em movimentos sociais (PSB e PT), etc. Porém, alguns requisitos nos chamam a atenção, como o de ter potencial eleitoral e possuir condições financeiras de arcar com as despesas de campanha (PFL, PL, PMDB e PSDB). A exigência do cumprimento de requisitos por parte dos partidos não pode ser classificada como negativa, embora devemos atentar para a importância de que os requisitos estabelecidos não sejam um fator de exclusão do processo de competição política, como pode ser o caso do último requisito citado - possuir condições financeiras de arcar com as despesas de campanha -, que pode ser um componente de limitação da candidatura, vinculando-a ao poder econômico do candidato, o que acaba reduzindo a participação política a uma pequena parcela economicamente privilegiada da população. De qualquer maneira, o que Braga e Praça (2007) nos permitem observar é que todos os partidos políticos lançam mão de restrições

\footnotetext{
${ }^{42}$ O PFL aprovou, em convenção nacional, a mudança do nome da legenda para Democratas (DEM) em março de 2007 (MATAIS, 2007).

${ }^{43}$ A tabela completa com as exigências de cada um dos partidos citados se encontra em BRAGA; PRAÇA (2007), p.193.
} 
informais para aqueles que almejam concorrer a uma cadeira no legislativo, o que confere aos partidos poder em relação às candidaturas.

No que se refere ao o sistema partidário brasileiro, podemos dizer que este não possui forte enraizamento na sociedade, sendo a filiação partidária bastante baixa, o que faz com que o volume de contribuições de membros do partido seja, também, muito baixo. Além disso, há o fato de os partidos não desenvolverem ou raramente desenvolverem atividades que possam agregar dígitos aos seus fundos, como a publicação de jornais, o oferecimento de seguros, serviços e cursos, etc. Sendo assim, o financiamento político brasileiro depende muito de outras fontes, sobretudo a privada (SPECK, 2003a).

Em seu artigo de 2003, "O financiamento político no Brasil - normas e práticas vigentes”, Bruno Speck nos apresenta e debate cinco questões referentes à relação existente entre o financiamento político e o funcionamento da democracia no Brasil: o custo das eleições no Brasil, a configuração da distribuição destes recursos, se os recursos disponíveis numa campanha rendem votos na mesma proporção e se o financiamento político resulta em favores pelos eleitos.

De acordo com David Samuels (2006, p.138), as despesas relativas às eleições de 1994, no Brasil, variaram entre 3,5 e 4,5 bilhões de dólares (contra cerca de 3 bilhões de dólares gastos nas eleições presidenciais americanas). Em 1994 e 1998, Fernando Henrique Cardoso, que foi eleito em ambos os pleitos, declarou ter gasto mais de 40 milhões de dólares em sua campanha. O que vale observar é que, enquanto em outros países, como os Estados Unidos, os candidatos precisam comprar espaço nos meios eletrônicos (rádio e TV), no Brasil esses espaços são gratuitos, isto é, são uma forma de financiamento público com recursos provenientes de renúncia fiscal. De qualquer maneira, a abundância de recursos é vista como algo desejável, sendo a escassez de recursos vista como uma ameaça 
à representação democrática, sobretudo num país de dimensões continentais como o Brasil (SPECK, 2003a, p.4). Sabendo que os recursos disponíveis são abundantes, é importante pensarmos na configuração da distribuição destes recursos dentre os vários candidatos. No caso brasileiro, os recursos são alocados quase que exclusivamente aos candidatos, individualmente, e a eles atribuídos. Como já citamos anteriormente, partidos e candidatos recebem recursos muito desiguais, até mesmo desequilibrando a competição eleitoral, ficando longe de um modelo ideal de competição justa. Mas qual a origem desse financiamento? O financiamento político se origina de três tipos de fontes: de recursos do próprio candidato ou do partido, de recursos diretos ou indiretos do Estado e de recursos de pessoas físicas e jurídicas. Como já mencionamos, o auto-financiamento por parte de partidos e candidatos é algo que caiu em desuso nos dias atuais. O financiamento público é proveniente do orçamento da União e de multas aplicadas aos partidos. Dada a importância crescente dos recursos financeiros para as campanhas, faz pertinente questionarmos se estes recursos disponíveis para uma campanha rendem votos na mesma proporção. No caso do Brasil, a resposta a esta afirmativa é positiva. Os candidatos que não alcançam determinado valor em arrecadação não conseguem obter votos suficientes para se eleger. Evidentemente o financiamento não é condição suficiente para se eleger - outros fatores como imagem, proposta de governo e os outros candidatos influenciam neste ponto, haja visto o perfil comparativo da representação, ou seja, a análise do eleitor leva em conta o conjunto dos estímulos por ele recebido -, mas é, sim, condição necessária. Por último é levantado o questionamento acerca do fato de o financiamento político resultar ou não em favores pelos eleitos. Não existem estudos sistemáticos, sobre o caso brasileiro, que vinculem o financiamento ao comportamento dos representantes eleitos em suas decisões tomadas. Por outro lado, Bruno Speck (2003a, p.7) apresenta dados da ONG Transparência Brasil sobre o 
grau de dependência dos representantes em relação aos seus maiores financiadores. Uma das observações que merece destaque diz respeito aos candidatos ao cargo de deputado federal em 2002: grande parte dos candidatos receberam 100\% de seus recursos de uma única fonte, e apenas cerca de $10 \%$ dos candidatos conseguiram diversificar suas fontes de arrecadação, de forma a não concentrar mais de $20 \%$ do total arrecadado sobre um único doador. Isso é confirmado pelo relatório de 2008 da Transparency International e pelo Insituto Ethos (GONÇALVES, 2008) sobre responsabilidade social empresarial no processo eleitoral. No relatório afirma-se que, mesmo em países com predomínio de grandes financiadores, seria possível que candidatos e partidos fossem financiados por diversas fontes, o que garantiria maior independência. Porém, o que se verifica é que, ao menos no caso do Brasil, ocorre o contrário: o financiamento concentra-se nas mãos de poucos doadores que, por sua vez, realizam doações de valores elevados. Os dados mais relevantes correspondem às eleições de 2004 para Prefeito, quando os candidatos eleitos receberam cerca de metade (49\%) de seus recursos de uma única fonte; nas eleições de 2006 para deputado federal esse número foi de 31\%; nas eleições de 2006 para deputado estadual esse número foi de $39 \%$ e nas das eleições de 2004 para vereador, foi de $80 \%$ (GONÇALVES, 2008, P.20).

No caso brasileiro as doações privadas possuem alguns vetos e limites. Nos últimos anos a legislação referente ao tema vem sofrendo várias alterações, com algumas características mantendo-se constantes e outras ajustando-se aos acontecimentos decorrentes da realidade política. A legislação mais importante sobre o tema está contida na Lei Orgânica dos Partidos Políticos de 1995 (Lei 9.096) e na Lei Eleitoral de 1997 (Lei 9.504). De acordo com a legislação, os partidos políticos no Brasil não podem receber recursos de entidade ou governo estrangeiros; autoridade ou órgãos públicos (salvo as 
doações referidas no artigo 38 - Fundo partidário); autarquias, empresas públicas ou concessionárias de serviços públicos, sociedades de economia mista e fundações instituídas em virtude de lei e para cujos recursos concorram órgãos ou entidades governamentais; entidade de classe ou sindical (Lei dos Partidos Políticos, art. 31). De maneira semelhante, no caso das campanhas eleitorais, é vedada a doação por parte de entidade ou governo estrangeiro; órgão da administração pública direta ou indireta ou fundação mantida com recursos provenientes do Poder Público; concessionário permissionário de serviço público; entidade de direito privado que receba, na condição de beneficiária, contribuição compulsória em virtude de disposição legal; entidade de utilidade pública; entidade de classe ou sindical; pessoa jurídica sem fins lucrativos que receba recursos do exterior (Lei Eleitoral, art. 24). Este quadro é semelhante ao encontrado em diversos países, havendo duas características peculiares do caso brasileiro: enquanto as contribuições de entidades de classe e sindicatos são vetadas, empresas privadas possuem carta branca para contribuírem (até o limite de $2 \%$ do faturamento bruto do ano anterior à eleição). Além disso, enquanto as contribuições por parte de concessionárias do poder público são proibidas, as contribuições por parte de contratantes de serviços e obras públicas é livre. Somando-se a essas características o fato de as doações privadas estarem vinculadas ao poder econômico do contribuinte (até $2 \%$ do faturamento bruto do ano anterior à eleição para pessoas jurídicas e até $10 \%$ do faturamento bruto do ano anterior à eleição para pessoas físicas), podemos afirmar que a legislação brasileira é muito liberal no que se refere aos vetos e limites para o financiamento político (SPECK, 2003a, p.7).

No que se refere aos subsídios públicos, existem os diretos e os indiretos. Os subsídios indiretos incluem, dentre outros, o acesso gratuito a instalações públicas para realização de reuniões e convenções, por exemplo, e possuem pouco peso. O financiamento 
direto (feito em espécie) passou a atingir peso econômico em meados dos anos 1990 (SPECK, 2003a, p.8), mais especificamente em 1996, quando o Fundo Partidário - criado nos anos 1960 - passou a receber recursos consideráveis do Tesouro (a maior parte do dinheiro $^{44}$ é proveniente do orçamento da União, e uma pequena parte é proveniente de multas aplicadas aos partidos). O valor total do fundo no ano de 2006 girava em torno de 150 milhões de reais (BRAGA; BOURDOUKAN, 2008, p.21). Existem dois modelos de distribuição deste montante: o igualitário e o proporcional, sendo $99 \%$ dos recursos distribuídos de maneira proporcional e $1 \%$ de maneira igualitária. O dinheiro oferecido pelo subsídio público direto representa apenas cerca de $10 \%$ do montante gasto na campanha e pode ser cortado, caso o partido não preste contas adequadamente (SPECK, 2003a, p.8).

No entanto, o subsídio mais relevante é o espaço gratuito para propaganda política que, no Brasil, estende-se a praticamente todos os veículos de comunicação social (rádio e televisão, pública e gratuita). Durante o período eleitoral (45 dias) há aproximadamente uma hora de propaganda, distribuída dentre todos os partidos, tanto no rádio quanto na TV; ao longo do ano, 80 minutos são dedicados à propaganda eleitoral gratuita para os grandes partidos. Este considerável tempo dedicado à propaganda eleitoral gratuita é complementado com a proibição de contratação de espaço extra e com regulamentações severas com o objetivo de coibir o favorecimento ${ }^{45}$ de determinado partido político ou candidato por parte das emissoras. A propaganda eleitoral gratuita foi instituída no Brasil

\footnotetext{
${ }^{44}$ De acordo com o artigo 38 da Lei dos Partidos Políticos (nº 9096 de 1995), o Fundo Partidário é constituído por multas e penalidades pecuniárias aplicadas nos termos do Código Eleitoral e leis conexas; por recursos financeiros que lhes forem destinados por lei, em caráter permanente ou eventual; por doações de pessoas física ou jurídica, efetuadas por intermédio de depósitos bancários diretamente na conta do Fundo Partidário; e por doações orçamentárias da União em valor nunca inferior, cada ano, ao número de eleitores inscritos em 31 de dezembro do ano anterior ao da proposta orçamentária, multiplicados por trinta e cinco centavos de real, em valores de agosto de 1995. Além disso, é pertinente observar que, de acordo com o artigo 44 da Lei dos Partidos, pelos menos 20\% dos recursos oriundos do Fundo Partidário deve ser destinado à criação e manutenção de instituto ou fundação de pesquisa e de doutrinação e educação política.

${ }^{45}$ Aqui entram possíveis favorecimentos em noticiários, programas em geral, entrevistas e debates.
} 
há quatro décadas e se manteve mesmo durante o regime autoritário, ainda que com ressalvas. Isso faz com que os candidatos e partidos tenham adquirido larga experiência neste meio de comunicação com o eleitor, tanto no que se refere ao uso do espaço quanto à fiscalização do uso do mesmo, feito pelos adversários.

No que se refere à distribuição do espaço, encontramos critérios igualitários e proporcionais, baseados nas vagas conquistadas na última eleição para a Câmara dos Deputados. No que se refere aos custos, os eleitores estão acostumados a uma propaganda de alto nível, e o tempo disponível - como há proibição de espaço extra - deve ser utilizado da maneira mais proveitosa possível, com o objetivo de maximizar os resultados. Com isso, a produção desses programas e a estrutura geral montada tendo em vista a campanha de mídia, acaba sendo cara, a exemplo dos $\mathrm{R} \$ 25$ milhões pagos pelo Partido dos Trabalhadores (PT) a Duda Mendonça pela campanha de mídia das eleições presidenciais de 2002 (GALL, 2005, p.6).

A legislação atualmente em vigor no Brasil "enfatiza especialmente a transparência do financiamento eleitoral e do acesso gratuito aos meios de comunicação, em detrimento de aspectos como o veto e limitações a fontes e valores" (SPECK, 2003a, p.12). Um dos maiores desafios enfrentados pela Justiça Eleitoral está na busca por uma maior justiça distributiva no tempo oferecido aos partidos políticos no horário político eleitoral, razão pela qual a administração da distribuição desse tempo e dos conflitos provenientes dessa distribuição acabam ocupando grande parte do tempo dos Tribunais Eleitorais.

No que se refere à transparência sobre as contas de partidos e candidatos, desde 1993 a prestação de contas deve ocorrer em até 30 dias após as eleições (Lei Eleitoral, art. 29); desde 1995 o balanço sobre contas partidárias deve ocorrer e até 120 dias após o ano fiscal (Lei dos Partidos Políticos, art. 32); a origem das doações devem ser identificadas 
individualmente; os dados sobre partidos são publicados anualmente em diários oficiais (de fato não acessíveis) e, desde 2002, o acesso aos dados sobre financiamento eleitoral pode ser feito através da Internet (SPECK, 2003b, p.16).

\subsection{O problema do "caixa dois" e o "Mensalão"}

É de comum acordo, dentre os analistas políticos do caso brasileiro, que os números apresentados nas prestações de contas não refletem completamente a realidade. Existe a desconfiança da existência do chamado "caixa dois" em praticamente todas as campanhas.

Bruno Speck (2003a, p.9) observa que o motivo principal dessa disparidade de informações não está no desconhecimento da legislação ou na tentativa de contornar limites e vetos contidos na legislação vigente. As informações sobre a legislação são detalhadas e abrangentes, e a Justiça Eleitoral procura desenvolver um trabalho contínuo na disseminação desta informação.

Um ponto específico da legislação pode gerar dúvidas no processo do financiamento político, abrindo brechas para possíveis fraudes, qual seja: "todo cidadão poderá contribuir com até mil UFIR para campanhas, sem que estas contribuições precisem ser declaradas na prestação de contas do candidato beneficiado" (Lei Eleitoral, art. 27) (SPECK, 2003a, p.9) - aqui facilita-se a entrada de contribuições anônimas, ainda que somente de pessoas físicas, com a justificativa de tratar-se de aportes não registrados por cidadãos diversos (SPECK, 2003a, p.9).

Aqui toma forma uma importante questão: em sendo a legislação brasileira relativamente liberal no que se refere às doações privadas, e se os candidatos correm o risco 
de terem sua candidatura ou mandado cassados, caso seja verificada alguma irregularidade, o que motivaria a existência de um "caixa dois"?

Dentre as respostas a este questionamento encontra-se uma bastante grave, referente à origem dos recursos destinados ao "caixa dois". Normalmente este dinheiro é proveniente de ações ilícitas, tratando-se de dinheiro não declarado da empresa, ou seja, oriundo de sonegação de impostos, tendo origem em um “caixa dois” já dentro da mesma ou dinheiro proveniente do crime organizado; o destino do dinheiro é ilícito, ou seja, trata-se de valores destinados a gastos com cabos eleitorais, compra de votos, etc; ou a motivação da doação é ilícita, tendo como objetivo a compra de favores e influência (SPECK, 2003a; FLEISCHER, 2000). De acordo com David Samuels, as empresas são responsáveis pela maior parte dos recursos disponíveis aos candidatos - valendo ressaltar que são poucas as empresas que doam ${ }^{46}$, e sobretudo ligadas a setores econômicos especialmente vulneráveis à intervenção ou regulação governamental, como o setor financeiro (inclui bancos), o setor da construção (dominado por empreiteiras e outras firmas do setor da construção civil) e o setor da indústria pesada (como aço e petroquímicas) (SAMUELS, 2003a, p.372-376). Deste modo, providenciar que as empresas tenham menos incentivos para manterem grandes somas de dinheiro fora do sistema bancário e não declarado ao governo, é uma das únicas maneiras de se eliminar o "caixa dois" (SAMUELS, 2003a, p.386).

\footnotetext{
${ }^{46}$ Aqui Samuels (2003) chama a atenção para o fato de, além das empresas dominarem o cenário das doações a candidatos políticos, tanto as doações provenientes de pessoas físicas quanto as provenientes de pessoas jurídicas estão concentradas em poucos doadores. Poucas pessoas físicas fazem doações, em comparação com a população total do país, e muitos dos contribuintes são parentes do candidato, pois possuem o mesmo sobrenome (Samuels chegou a esta conclusão analisando os dados do TSE de 1994 e 1998), e relativamente poucas empresas fazem doações por candidato. Esta situação reflete o cenário socioeconômico do Brasil: poucos são os doadores, porém doam altos valores, espelhando a distribuição desigual de renda presente no país." Uma porcentagem muito pequena da população do país possui uma receita disponível suficiente para querer e poder influenciar o processo político, mediante consideráveis quantias doadas para fundos de campanha" (SAMUELS, 2003, p.381).
} 
O tema do "caixa dois" ganhou grande notoriedade no cenário político brasileiro no ano de 2005 quando, ao final do terceiro ano de mandato do Presidente Lula, a política brasileira defrontou-se com o episódio que é considerado o maior esquema de "caixa dois" já tornado público na política brasileira: o chamado "Mensalão".

O então deputado e presidente do Partido Trabalhista Brasileiro (PTB), Roberto Jefferson denunciou o esquema, que quase destruiu o governo do Presidente Lula e o Partido dos Trabalhadores (PT). A denúncia ocorreu porque Jefferson confessou que havia negociado pagamentos num total de 20 milhões de reais com dirigentes do PT, mas recebera apenas 4 milhões. Sentindo-se traído, resolveu tornar público o esquema. Esta denúncia acabou desencadeando

uma enxurrada de revelações de fraude, lavagem internacional de dinheiro, financiamentos ilegais de campanhas eleitorais, compra de votos de parlamentares, contratos governamentais ilícitos e o roubo de grandes somas de prefeituras e de bancos, grandes empresas e seguradoras pertencentes ao governo federal, além de investimentos muito suspeitos feitos por fundos de pensão ligados ao setor público (GALL, 2005, p.1).

A maior transferência conhecida de dinheiro até então envolvia $\mathrm{R} \$ 15,5$ milhões pagos à Duda Mendonça, marketeiro da campanha de Lula. Mendonça afirmou, na CPI, que recebera o dinheiro, parte dos $\mathrm{R} \$ 25$ milhões cobrados por ele para desenvolver a campanha de mídia de Lula, sabendo que ele era proveniente de "caixa dois", mas que era a única maneira de receber o valor que estava pendente. Estima-se que, no total, cerca de 2 bilhões de reais estavam envolvidos no esquema, sem origem definida. Embora pagamentos não registrados e transferências entre contas clandestinas no exterior sejam tolerados há muito tempo na política brasileira, operações de tamanha magnitude e o esquema de 
pagamento de propinas em valores tão altos em dinheiro foram uma surpresa para a opinião pública (GALL, 2005, p.4).

O PT desenvolveu este esquema com o intuito de conseguir poderes ampliados para Lula e o partido através da compra de votos da oposição, mas as denúncias acabaram com essas expectativas e quase derrubaram o governo. De acordo com autores como Norman Gall (2005) e Francisco de Oliveira (2006) o episódio manchou a imagem de Lula e do PT, sobretudo pelo posicionamento que adotavam até então, resultando em perda do patrimônio ético e moral do partido. Lula era a imagem da esperança de ascensão para brasileiros que se encontravam em classes desprivilegiadas e, tanto ele quanto o partido, levantavam a bandeira de ética e moral na política, denunciando escândalos reais ou não em governos anteriores.

Instaurou-se uma CPI (Comissão Parlamentar de Inquérito) durante o período de 21 de julho de 2005 e 17 de novembro de 2005, para averiguar as acusações e concluiu-se que houve a distribuição de recursos ilegais a parlamentares com periodicidade variável mas constante durante os anos de 2002 e 2003, ainda que não tenha sido possível definir se essa periodicidade era mensal, como afirmava Jefferson. Diversos membros do governo tiveram seus nomes associados ao escândalo ${ }^{47}$.

Bresser-Pereira (2006, p.38) teceu o seguinte comentário sobre o episódio:

O governo Lula e o PT reconheceram as irregularidades, mas tentaram identificá-las com "caixa dois" em campanhas eleitorais, ou seja, com doações

\footnotetext{
${ }^{47}$ Dentre as figuras mais abaladas com o escândalo destacam-se o então Ministro da Casa Civil, José Dirceu, e o então presidente do PT, José Genoíno. José Dirceu foi apontado como sendo um dos "cabeças" do esquema e foi acusado por Jefferson de chefiar indicações para cargos em estatais com o objetivo de captar recursos para o PT. Dirceu deixou o Ministério e perdeu seus direitos políticos até 2015. José Genoíno foi denunciado por corrupção, acusado de negociar o pagamento a parlamentares em troca de apoio político. Renunciou à presidência do partido e foi eleito deputado federal em 2006 (Folha Online de 09/09/2005).
} 
de dinheiro não declaradas ao fisco e aos tribunais eleitorais. Dessa forma, o PT estaria fazendo algo usual no processo de financiamento de campanhas eleitorais. Ao longo desse escândalo, porém, foi ficando claro que o processo envolvia corrupção stricto sensu, seja pela compra de votos de deputados de outros partidos, seja pelo fato de os recursos provirem de empresas estatais cujos contratos de publicidade eram sobrefaturados ou de fornecedores do Estado, que compensavam as doações com sobrefaturamento dos serviços. Além disso, não se tratava de simples financiamento de campanhas eleitorais, já que o sistema passou a fazer parte do governo federal, como antes fizera parte dos governos municipais em que o PT elegera o prefeito. (BRESSERPEREIRA, 2006, p.38)

Em entrevista concedida em 2005, o Presidente Lula, tentando "minimizar" o episódio, declarou que "o que o PT fez, do ponto de vista eleitoral, é o que é feito no Brasil sistematicamente" (GALL, 2005, p.5). Tal declaração remete a uma outra declaração dada em meio a outro grande escândalo político vivido pelo Brasil pós-redemocratização - a renúncia de Fernando Collor de Mello, em 1992, primeiro Presidente eleito da história da América Latina a sofrer impeachment, após a descoberta de um esquema de grandes proporções de pagamento de subornos e comissões ilícitas ao seu governo - por Paulo César Farias, tesoureiro da campanha de Fernando Collor de Mello, próximo ao julgamento de impeachment, quando ele fez a seguinte declaração na CPI: "Estamos todos sendo hipócritas. Ninguém obedece à lei do financiamento de campanhas".

Sem dúvida alguma a maneira como o financiamento de campanhas parece ser encarado por políticos e demais atores envolvidos na política brasileira, é alarmante. As declarações acima nos remetem à idéia de falta de fiscalização e de impunidade presente no sistema político brasileiro. Trata-se de uma cultura política corrupta e deteriorada, arraigada na classe política, que pede medidas urgentes para que o financiamento político possa ser encarado sob seu aspecto mais nobre: o de fundos para promover a competição política 
livre, igual e justa, e não como uma maneira de colocar em prática atos corruptos e ilegais, de suborno, compra de acesso e compra de influência, dentre outros atos ilícitos.

Face aos problemas enfrentados, o debate contido no Projeto de Lei 2679/03, que propõe o fim do financiamento privado no Brasil e a exclusividade do financiamento público, ganhou força no cenário político brasileiro (ABRAMO, 2005, p.6).

\subsection{O Projeto de Lei 2679 de 2003}

No Brasil, a proposta de reforma política contida no Projeto de Lei 2679 de 2003 prevê, basicamente, três importantes alterações. São elas: a ampliação do financiamento público para partidos de $\mathrm{R} \$ 120$ milhões para, aproximadamente, $\mathrm{R} \$ 800$ milhões; a proibição de qualquer tipo de doação privada em anos eleitorais, em outras palavras, o financiamento público tornar-se-ia a única fonte de custeio para as campanhas eleitorais; e, por fim, a adoção do voto de legenda puro, no qual o eleitor não mais votaria num candidato, mas sim nos partidos que, por sua vez, seriam responsáveis por elaborar uma lista fechada de candidatos, previamente às eleições (a proposta de lista fechada para a eleição de vereadores e deputados foi derrubada pela Câmara dos Deputados em junho de 2007). No projeto, os parlamentares justificam as propostas fazendo menção aos problemas da dependência e desigualdade criados pelo financiamento privado - problemas estes que o financiamento misto, segundo o texto, não é capaz de sanar, uma vez que "o convívio entre financiamento público e privado é problemático porque não inibe a ação do poder econômico, razão pela qual optamos, neste projeto, pelo financiamento público exclusivo" (Projeto de Lei 2679 de 2003) - e à indisciplina partidária. 
Agora, passemos a analisar os argumentos a favor e contra cada uma das formas de financiamento encontrados na bibliografia analisada.

3.6. Argumentos contra e a favor de cada uma das formas de financiamento político

Argumentos a favor do financiamento público

De acordo com David Samuels, o financiamento público possui argumentos a seu favor, como o fato de ser altamente "democrático", já que "garante um nível de financiamento para todos os partidos, independentemente de os seus eleitores serem ricos ou pobres" (SAMUELS, 2003, p.384; 2006, p.149).

Além disso, em tese, o financiamento público reduziria o impacto dos interesses econômicos na política e fortaleceria os partidos políticos, pois eliminaria a busca desenfreada dos candidatos por dinheiro do interesse econômico privado e forçaria os partidos a adotar estratégias de campanhas voltadas para programas de políticas nacionais mais claras para o eleitorado (SAMUELS, 2003, p.384; 2006, p.149).

No texto de Delia Rubio, encontramos o argumento de que o financiamento público exclusivo evitaria as conseqüências negativas do financiamento privado, além de diminuir os gastos com a competição política, aumentando a eqüidade do processo. De acordo com 
Rubio, o financiamento público de partidos políticos e campanhas eleitorais produz os seguintes incentivos:

Gera condições de competição eleitoral eqüitativa; promove a participação de partidos ou candidatos que carecem de recursos e não têm capacidade de arrecadação; evita a pressão direta ou indireta dos capitalistas e doadores sobre os atores políticos; diminui a necessidade de fundos dos partidos e candidatos; reduz o potencial de corrupção; contribui para a sustentação e o fortalecimento dos partidos como atores fundamentais para o funcionamento das democracias representativas. (RUBIO, 2005, p.8)

\section{Argumentos contra o financiamento público}

Atualmente, são poucas as democracias que não possuem alguma forma de subsídio público, quer isso se faça por meio de incentivo ou de renúncias fiscais, quer por meio da distribuição de recursos orçamentários propriamente dita e de acesso gratuito aos meios de comunicação eletrônicos (rádio e televisão). Espera-se que uma das consequiências do financiamento público seja a redução da pressão pela busca de financiamento privado (SPECK, 2004h, p.2). No entanto, é importante observar que não há, hoje, nenhum país que tenha introduzido o financiamento público exclusivo, em detrimento de todas as modalidades de financiamento privado.

O financiamento público exclusivo possui pontos negativos e, dentre eles, Speck nos chama a atenção para a questão da distribuição dos recursos. Existem várias 
modalidades ${ }^{48}$, dentre as quais podemos destacar o financiamento igualitário, a distribuição de recursos de forma proporcional (pré e pós-eleição) e o financiamento que incentiva a arrecadação de fundos junto aos filiados e simpatizantes. Um primeiro problema é o de que o financiamento público, como proposto pelo Projeto 2679 de 2003, desestimula a competição política e favorece o situacionismo. No Brasil e em muitos outros países, existe o financiamento proporcional pré-eleição, que leva em conta o histórico do partido, distribuindo recursos com base em seu desempenho nas eleições passadas. Este modelo tende a favorecer o governismo ao dar vantagem para aqueles que ganharam as eleições anteriores, e a desfavorecer a oposição, além de ser totalmente incompatível com a proposta do financiamento público exclusivo.

Além disso, existem outros pontos negativos, como o risco de que haja uma diminuição da liberdade dos partidos; o afastamento do partido de suas bases, enfraquecendo seus (já frágeis) laços com a sociedade devido à redução da necessidade de ampliar a filiação partidária, o que resultaria da dependência excessiva dos cofres públicos, por parte dos partidos (ZOVATTO, 2005, p.300). Este segundo ponto merece atenção, pois a falta de vínculos entre sociedade e partidos é um dos maiores problemas de nosso sistema partidário, como podemos observar no texto de Maria D’Alva Gil Kinzo, “Os partidos no eleitorado: percepções políticas e laços partidários”, de 2007. Partindo da idéia de que, em regimes democráticos, os partidos políticos são importantes estruturadores e facilitadores da orientação eleitoral, Kinzo frisa a importância de que estes gozem de uma visibilidade

\footnotetext{
${ }^{48}$ No financiamento igualitário cada partido recebe um mesmo valor dos fundos públicos, baseado na idéia de que todos devem gozar de oportunidades eqüitativas para participar. Na distribuição proporcional pós-eleição é adotado o método do reembolso proporcional ao número de votos obtidos na eleição. Assim, é levado em conta o sucesso na disputa eleitoral em questão. Esta forma de financiamento está presente na Costa Rica. O financiamento que incentiva os partidos a arrecadarem fundos junto aos seus filiados e simpatizantes paga um determinado valor para cada valor arrecadado. Esta forma de financiamento está presente na Alemanha. (SPECK, 2004f).
} 
satisfatória na competição eleitoral, sendo esta visibilidade combinada à contínua participação eleitoral, os propiciadores de uma lealdade partidária. Neste trabalho, Kinzo destaca o papel dos partidos políticos como agentes que organizam o processo eleitoral e questiona o quanto os partidos fazem alguma diferença sob o ponto de vista do eleitor, avaliando até que ponto eles são capazes de "oferecer aos eleitores opções políticas distintas o suficiente para construir suas identidades, criar lealdade e servir como atalho no ato de votar" (KINZO, 2007, p.20). O nível de volatilidade eleitoral brasileiro está dentre os mais altos do mundo e, ainda que tenha parado de crescer recentemente, estacionou num patamar considerado alto: $30 \%$. Um dos fatores mais importantes apontados para que este quadro se verificasse seria o impacto da era televisiva, ocorrido em todas as partes do mundo e responsável pelo fato de a campanha concentrar-se muito mais em personalidades do que em partidos. No caso do Brasil isso é reforçado pelo fato de a democracia ainda ser uma instituição jovem no país e pela estrutura de incentivos na disputa por votos - a estratégia adotada por candidatos e partidos cria uma situação na qual o personalismo é favorecido e a competição partidária torna-se "nebulosa". Tanto nas campanhas eleitorais legislativas quanto nas executivas não há foco nos partidos como atores distintos, mas sim em candidatos individuais - ou em alianças partidárias - o que torna improvável o estabelecimento de laços entre partidos e eleitores. Desta maneira os partidos políticos acabam gozando de menor visibilidade, o que dificulta a fixação de uma imagem junto ao eleitorado, bem como a criação de identidades e conexão com os eleitores. Aliada à esta dificuldade de fixação de uma imagem, como sua causa e conseqüência, Kinzo identifica a falta de informação a respeito dos partidos - que possibilitasse ao eleitorado diferenciá-los - como sendo preponderante para que se verifique a ausência de lealdade ou laços 
partidários. Deste modo, a falta de vínculo entre sociedade e partidos estaria muito mais relacionada à falta de informação do que a um sentimento de rejeição à política partidária.

Duas questões permanecem sem resposta quando falamos de financiamento público: “quanto dinheiro o governo distribuiria aos partidos políticos?" e "quem controlaria a distribuição de dinheiro?"

No que se refere à primeira questão, no caso do Brasil, as propostas existentes acabariam por oferecer aos candidatos um valor muito menor (cerca de R $\$ 800$ milhões distribuídos dentre todos os partidos) do que aquele que muitos analistas e jornalistas estimam como sendo o montante gasto nas eleições. Isso faz com que voltemos ao antigo impasse: isso acabaria com a corrupção ou incentivaria ainda mais a existência de um “caixa dois"? Podemos, de fato, confiar na idéia de que os partidos conseguiriam financiar seus candidatos com um valor muito menor do que o habitual? No que se refere à segunda questão, há o problema as relações de poder que se estabeleceriam em decorrência do financiamento público exclusivo. $\mathrm{Na}$ maioria dos países que possuem financiamento público de campanhas, quem detém o papel central na decisão sobre os gastos e distribuição dos recursos é a liderança nacional do partido, que passa a ter imenso poder com a decisão de favorecer este ou aquele candidato em detrimento de outros. Quem tem este poder de decisão nas mãos pode, por exemplo, decidir favorecer os candidatos mais competitivos. Porém, a decisão sobre quais seriam os candidatos mais competitivos, permanece confusa e subjetiva. De qualquer maneira, quem detiver este controle do dinheiro, possuirá imenso poder dentro do processo político-eleitoral. (SAMUELS, 2006, p.150)

Outro ponto negativo consiste no fato de que o financiamento privado continuará a existir, porém, de maneira ilegal, uma vez que sempre existirão grupos ou indivíduos 
interessados em colaborar com partidos políticos e candidatos; e a necessidade de ampliação da parcela do orçamento público destinada ao financiamento político (Rubio, 2005). Aqui entra o já citado problema do "caixa dois", para o qual nos chama a atenção David Samuels $(2003 ; 2006)$. De acordo com o autor, o financiamento público, apesar de todas as suas qualidades, não garantiria a extinção do "caixa dois", pelo contrário: poderia até mesmo favorecê-lo, caso tal reforma do sistema de financiamento de partidos e campanhas não viesse acompanhada de reformas tributária e financeira ${ }^{49}$, altamente atreladas umas às outras, e também ao fortalecimento do Tribunal Superior Eleitoral. O dinheiro proveniente do "caixa dois" não costuma ser dinheiro lícito, não vindo do "caixa um" da empresa, mas sim de seu "caixa dois" interno, mantido pelas mesmas com o objetivo de empregar tais fundos em financiamento político ou outros objetivos semilegais ou até mesmo ilegais, como o tráfico de influência. O financiamento público não somente não seria eficaz em acabar com tais práticas como, no caso do Brasil, poderia até mesmo incentivá-las, dado o atual sistema eleitoral adotado. Como exemplo, temos o caso da Itália, que possuía um sistema eleitoral muito semelhante ao brasileiro e em 1970 adotou o financiamento público de campanhas. Em 1993 esta forma de financiamento foi abandonada no país devido ao grande aumento da corrupção, quando ocorreu o episódio conhecido como "Tangentopoli", que envolveu a descoberta de ampla rede de corrupção envolvendo lideranças de alguns dos principais partidos do país, grandes empresários e pessoas envolvidas no crime organizado (ARAÚJO, 2004, p.65). “Os reformadores

\footnotetext{
${ }^{49}$ No caso do Brasil Samuels aponta a criação da CPMF e a capacidade adquirida pelo governo em quebrar sigilos bancários como um grande avanço no que se refere à capacidade de o governo vigiar as transações e detectar fraudes, mas para que o "caixa dois" seja eliminado, muitos outros avanços ainda são necessários. A única maneira de efetivamente acabar com o "caixa dois" seria reduzindo ao máximo os incentivos que as empresas possuem para manterem grandes valores de dinheiro fora do sistema bancário e/ou fora do conhecimento do governo.
} 
associaram o sistema de financiamento público a mais, e não a menos corrupção" (SAMUELS, 2006, p.149).

Outro ponto, como bem observa Delia Rubio (2005, p.9), é o de que recairemos no problema da legitimação do financiamento público em países subdesenvolvidos ou expostos a crises econômicas. Nestes cenários, a alocação de recursos públicos para partidos políticos pode ser amplamente questionada pela sociedade. Tal questionamento é ainda maior quando a confiança nos partidos políticos encontra-se abalada.

Em resumo, o financiamento público exclusivo "cria um monopólio estatal, não elimina o "caixa dois" para partidos e sobrecarrega a Justiça Eleitoral" (SPECK, 2004h, p.2).

\section{Argumentos a favor do financiamento privado}

O financiamento privado não deve ser tratado como se fosse um único bloco homogêneo, haja vista a vasta gama de fontes privadas existentes ${ }^{50}$. Neste campo devemos tomar cuidado com generalizações: o financiamento privado de pequeno porte, proveniente das contribuições regulares dos filiados aos partidos, é algo positivo, pois se relaciona com o enraizamento do partido na sociedade, gerado pelo incentivo para recrutar novos membros; além disso, as contribuições feitas em períodos de campanha estão relacionadas com manifestações legítimas de apoio às candidaturas. Logo, o financiamento privado de pequeno porte é considerado altamente benéfico para a saúde da democracia representativa.

\footnotetext{
${ }^{50}$ O Projeto de Lei 2679 de 2003 não prevê essa diferença entre as fontes de financiamento privado, vedando toda e qualquer contribuição desse tipo (SPECK, 2004h, p.2).
} 
Sem dúvida, um dos maiores exemplos citados na mídia como campanha que envolveu grande número de doadores de pequenos montantes foi a campanha presidencial de Barack Obama, em 2008. A crença era de que Obama teria recebido metade de suas doações discretas em valores de 200 dólares ou menos ${ }^{51}$.

Porém, numa análise mais profunda, o The Campaign Finance Institute (CFI) observou que, na realidade, Barack Obama havia recebido mais ou menos a mesma porcentagem de pequenas doações que George Bush havia recebido em 2004. O CFI observou, também, que doações não são o mesmo que doadores, o que permitiu verificar que, na verdade, vários doadores repetiam suas doações (doavam mais de uma vez) à campanha de Barack Obama. A análise dos dados obtidos junto ao Federal Election Commission (FEC) permitem concluir que as doações repetidas e as grandes doações (contribuições de pelo menos 1000 dólares) foram mais importantes para Obama do que análises anteriores haviam apontado. $\mathrm{O}$ instituto chegou a esta conclusão ao analisar os dados do FEC a fim de identificar doadores repetidos e categorizar cada doação de acordo com a quantidade cumulativa doada por determinado indivíduo ao longo do ciclo eleitoral. Esse valor cumulativo se deu graças à duração da batalha entre Obama e Clinton pela nominação pela candidatura, à sua rejeição ao financiamento público para sua campanha, ao seu carisma pessoal e, acima de tudo, à maneira como sua campanha foi organizada. A maneira como se deu a organização da campanha de Obama tornou possível que se lançasse mão da Internet para retornar aos mesmos apoiadores repetidamente, quer fosse por assistência voluntária, quer fosse por contribuições repetidas.

\footnotetext{
${ }^{51}$ Os doadores são divididos da seguinte maneira: pequenos doadores (small donors) - doações no valor de 200 dólares ou menos; doadores médios (middle range) - doações no valor de 201 a 999 dólares; grandes doadores (large donors) - doações no valor de 1000 dólares ou mais.
} 
Desta maneira, a inovação na campanha de Obama não se deu pelo montante que ele conseguiu levantar junto a pequenos doadores, mas pelo número de pessoas que ele conseguiu alcançar: de acordo com estimativas do CFI o candidato teria contado com a colaboração de cerca de 2,5 milhões de pequenos doadores, que seria um número bastante similar ao número de pequenos doadores que teriam doado para todos os candidatos somados nas eleições de 2004 (algo entre 2 e 2,8 milhões de doadores).

De acordo com Michael J. Malbin, diretor executivo do CFI, a idéia de que o dinheiro proveniente de pequenos doadores dominou as finanças de Barack Obama é um mito. Porém, isso não tira a importância da campanha de Obama, em termos da inovação do uso redes sociais online para angariar fundos e atrair voluntários para sua campanha e pelo fato de ele ter quebrado recordes em termos de contribuição, em todos os níveis (small donors, middle range e large donors).

Em resumo, como já havíamos observado anteriormente em Rubio (2005), impedir o financiamento privado de pequeno porte seria prejudicial aos laços, já tão tênues, existentes entre partidos políticos e eleitores, além do risco real de se estabelecer uma legislação de fachada, haja vista os escândalos passados ${ }^{52}$ vividos pela política brasileira.

Além disso, em termos de financiamento político, a ausência de recursos é considerada um sinal mais alarmante do que sua abundância. Em todas as democracias e, especialmente em democracias com um sistema representativo de dimensões continentais (como é o caso do Brasil), a ausência de dinheiro significa maior dificuldade de o candidato se comunicar com seu eleitor, o que traz grandes ameaças à competição política (SPECK, 2003a, p.4).

\footnotetext{
${ }^{52}$ Em "Teses sobre a reforma do financiamento político no Brasil” Bruno Speck aponta os casos Collor/PC e Paubrasil/Maluf. Também podemos citar o caso do Mensalão, tratado nesta dissertação na sessão 3.3.
} 


\section{Argumentos contra o financiamento privado}

Dentre as críticas feitas ao financiamento privado, a principal é a de que essa modalidade abre espaço para que políticos passem a atuar como agentes do interesse privado daqueles que os financiam, e não mais como agentes do bem comum. Deste modo, o valor eqüitativo das liberdades políticas encontrar-se-ia seriamente ameaçado, com a compra de acesso e influência por parte dos financiadores. Ao invés de levarem em conta o bem comum e os interesses do eleitorado em geral, os políticos passam, então, a priorizar os interesses dos doadores. Deste modo, como já citado, o princípio democrático de "um eleitor, um voto", que nos passa a idéia de eqüidade no poder de influenciar a competição política, encontrar-se-ia anulado, gerando desigualdade dentro do processo político. Além disso, a autonomia dos políticos é solapada, pois passam a depender dos doadores que doam esperando que se concretize uma troca de favores, uma vez que todos os doadores de grandes somas esperam algum benéfico específico em troca.

Vale ressaltar, mais uma vez, que o financiamento de pequeno porte é considerado benéfico para o sistema político: o que preocupa é o financiamento de grandes valores, por sua tendência a tornar a competição desigual e a gerar laços de dependência entre candidato e doador (SPECK, 2004h, p.2). É importante observarmos que as críticas feitas ao financiamento privado não são quantitativas, mas sim qualitativas: não se trata de diversas críticas enumeradas, porém, a crítica mais freqüente, que maiores preocupações causa, é exatamente o ponto crucial em torno do qual se dá toda a problemática em torno do financiamento de partidos políticos e campanhas eleitorais. Este ponto relacionado, como já dissemos, à influência dos doadores de altas somas sobre os políticos configura-se no principal ponto da discussão acerca da ameaça do poder econômico frente ao poder 
político, e aos riscos daí decorrentes para a democracia e a justiça. A representação e o valor eqüitativo das liberdades políticas são fortemente ameaçados através da prática descontrolada do financiamento privado.

Para evitar essa influência nociva do dinheiro na política, indo ao encontro da idéia de John Rawls, muitos países têm optado por impôr limites à contribuição privada, tanto no tocante ao montante com o qual se é permitido contribuir, quanto no que se refere à natureza do doador. No entanto, em determinadas circunstâncias - mais especificamente quando os montantes doados são baixos e os doadores são diversificados e em grande quantidade -, o financiamento privado pode ser garantia de pluralismo, já que o financiamento público exclusivo pode abrir espaço para que o governo lance mão de estratégias de exclusão em relação à oposição (RUBIO, 2005), além de contribuir (o financiamento privado) para que os partidos exerçam uma gestão mais eficiente de seus recursos (ZOVATTO, 2005).

\section{Argumentos a favor do financiamento misto}

Ambas as formas de financiamento - público e privado - possuem pontos negativos e positivos, e a combinação de ambas, o financiamento misto, é considerado ideal, para aqueles que defendem esse modelo (David Samuels, Delia Rubio, Bruno Speck, Daniel Zovatto, dentre outros autores), por sua possibilidade de englobar os lados positivos de ambas as formas de financiamento. $\mathrm{O}$ que esta forma de financiamento exigiria seriam alguns mecanismos que possibilitassem, senão anular, ao menos reduzir os riscos à manutenção do valor eqüitativo das liberdades políticas, no que se refere ao financiamento 
político. Deste modo, ações ilícitas e corruptas, como o tráfico de influência, poderiam ser detectadas e combatidas de maneira eficiente e, além disso, instituições e legislação poderiam atuar de maneira a garantir a igualdade política, colaborando com a manutenção do valor eqüitativo das liberdades políticas.

Para solucionar o problema do "caixa dois", Samuels sugere o financiamento misto - público e privado - associado a uma legislação que gerasse incentivos para que tanto políticos quanto doadores quisessem que seus nomes aparecessem na prestação de contas. Esta prestação de contas deveria, inclusive, ser apresentada durante as eleições e deveria estar disponível na Internet. Além disso, Samuels propõe:

reduzir o limite para a contribuição, aumentar a autovigilância entre os políticos, aumentar as penalidades por violação das lei e principalmente modificar substancialmente a legislação sobre bancos e impostos, para que pessoas físicas e jurídicas sejam menos encorajadas a manter grandes somas de dinheiro 'fora do livro', ou seja, fora da economia oficial. Obviamente, a tarefa não é fácil. Nenhuma lei pode resolver por si essa questão. (SAMUELS, 2006, p.150)

Em tese, o grosso da bibliografia sobre o tema por mim analisada discorda da observação contida no Projeto de Lei 2679 de 2003. Os autores destacam o financiamento misto - dominante na América Latina - como a melhor opção, salvaguardadas algumas observações.

Para Delia Rubio o mais aconselhável também seria estabelecer o sistema de financiamento misto, baseando o financiamento público em "critérios de distribuição que combinem os princípios de igualdade e proporcionalidade com algum elemento objetivo de enraizamento dos partidos na sociedade" (RUBIO, 2005, p.11) e regulando o privado de modo a "garantir transparência sobre o montante, a origem e o destino dos recursos 
recebidos, com as limitações que sejam oportunas segundo as condições de cada país" (RUBIO, 2005, p.11). Zovatto (2005) sugere um sistema de "matching" para evitar os possíveis efeitos burocratizantes do financiamento público. Neste sistema, uma parcela do dinheiro proveniente do Estado estaria relacionada à captação de recursos pelos partidos, como ocorre no modelo alemão ${ }^{53}$.

Por fim, devemos destacar a questão da necessidade de um marco legal eficaz e de um mecanismo de vigilância e aplicação de sanções eficaz e independente. De acordo com Zovatto (2005), um marco jurídico eficaz é primordial para o bom funcionamento do financiamento de partidos políticos e campanhas eleitorais, pois evita o abuso ou compra de influência nos partidos políticos por parte de grupos de interesse ou indivíduos detentores de grandes somas em dinheiro, restabelecendo a confiança dos cidadãos no processo político; permite que se estabeleça um jogo equilibrado para a competição entre partidos; permite aos cidadãos que obtenham informações para que possam, assim, tomar uma decisão bem informada no dia das eleições; para que haja um desenvolvimento e fortalecimento dos partidos a fim de torná-los atores mais responsáveis dentro do jogo político; e, por fim, para assegurar racionalidade no uso dos recursos públicos destinados para financiar a atividade político-eleitoral (ZOVATTO, 2005, p.293). Some-se a isso o fato de que o sucesso de qualquer sistema adotado depende da criação de um mecanismo de controle e aplicação de sanções eficiente e independente e "quanto maiores as restrições e proibições, tanto maiores deverão ser a independência política, a competência jurídica e a capacidade técnica operacional deste organismo" (RUBIO, 2005, p.11). Além disso, é necessário que se desenvolva uma cultura política de transparência e compromisso em

\footnotetext{
${ }^{53}$ No modelo alemão há incentivo para que os partidos arrecadem pequenas contribuições junto aos seus filiados e simpatizantes, e para cada Euro arrecadado de pessoas físicas até um determinado valor, o Estado paga outro Euro ao partido.
} 
relação à vigilância, tanto entre os atores políticos quanto entre a sociedade civil. No caso do Brasil

\subsection{Possibilidades de reforma}

Ao analisarmos as possibilidades de reforma do financiamento político, observamos a existência de três possibilidades, quais sejam (SPECK, 2006, p.155):

a) Impor limites e vedações à contribuição com o objetivo de minimizar os riscos provenientes do financiamento. Encontram-se neste pacote o veto à contribuição por parte de certos atores e o limite aos valores a serem doados. No caso do Brasil, a Lei dos Partidos de 1995 e a Lei Eleitoral de 1997 definem que

entidades ou governos estrangeiros, instituições públicas da administração direta ou indireta; empresas públicas e sociedades de economia mista, entidades subsidiadas com recursos públicos; entidades de utilidade pública; concessionárias e permissionários de serviços públicos, e entidades de classe ou sindical são vedadas de contribuírem com recursos para partidos e campanhas. (SPECK, 2006, p.156)

A vedação de contribuições por parte de entidades de classe e sindicatos é herança do período da ditadura militar e não existem motivos convincentes para que se perpetue até os dias de hoje. Por outro lado, a omissão da legislação brasileira no que se refere a contribuições por parte de empresas que prestam serviços ou realizam obras para o Estado e, no mínimo, 
questionável pois, aqui sim, existe um grande risco de haver troca de favores entre doador e governante eleito (SPECK, 2006, p.156).

Outro ponto muito questionado é a legislação referente ao montante que pode ser doado por entidades privadas. Enquanto A Lei dos Partidos nada fala a esse respeito, a Lei Eleitoral define um teto de $10 \%$ do faturamento bruto do ano anterior à eleição para pessoas físicas e $2 \%$ do faturamento bruto do ano anterior à eleição para pessoas jurídicas. Isso acaba por transformar a "iniqüidade social e econômica em norma para o financiamento eleitoral" (SPECK, 2006, p.156).

Por fim, não existe um teto limite para os gastos: a Lei Eleitoral apenas estabelece que os candidatos devam estipular um gasto e comunicá-lo à Justiça Eleitoral (Lei Eleitoral 9.504/97, art. 18).

Em resumo, podemos dizer que no tocante à legislação, o financiamento político no Brasil é muito permissivo no que se refere à origem e aos valores destinados ao financiamento de partidos e campanhas.

b) Regular o financiamento público a candidatos e partidos. Dentre as justificativas dadas para a existência do financiamento público está o papel desempenhado pelos partidos políticos ${ }^{54}$ dentro do sistema político: o de intermediário entre a sociedade e o poder público. Outro motivo seria a substituição total do financiamento privado pelo público, evitando, assim todas as mazelas decorrentes do financiamento através do dinheiro privado.

\footnotetext{
${ }^{54} \mathrm{O}$ artigo $1^{\circ}$ da Lei dos Partidos Políticos estabelece que "o partido político, pessoa jurídica de direito privado, destina-se a assegurar, no interesse do regime democrático, a autenticidade do sistema representativo e a defender os direitos fundamentais definidos na Constituição Federal.
} 
Dentre as formas de financiamento público estão "as isenções de impostos aos partidos e aos doadores; o acesso gratuito ou subsidiado a serviços públicos e instalações; os recursos orçamentários diretos" (SPECK, 2006, p.157). No caso brasileiro, um dos fatores mais importantes é o acesso gratuito aos veículos de comunicação eletrônicos (televisão e rádio, público e gratuito). A propaganda eleitoral gratuita foi introduzida no país em 1962 e foi complementada durante o regime militar, mais especificamente em 1974, pela proibição de compra extra de espaço nesses meios de comunicação. Também existe uma legislação densa que visa a coibir um possível favorecimento de determinado candidato por parte de alguma emissora. $\mathrm{O}$ espaço gratuito dado aos partidos e candidatos antes da eleição é bastante amplo, e é dividido, de acordo com a Lei Eleitoral, da seguinte maneira:

$1 / 3$ é alocado em frações iguais entre todos os partidos que apresentam candidatos na eleição e tiverem representação na Câmara dos Deputados. Com o número grande de partidos este espaço acaba sendo extremamente fracionado. Outros $2 / 3$ do tempo são distribuídos de forma proporcional à composição da Câmara no início do período legislativo. A vinculação de um dos mais importantes recursos na eleição ao sucesso eleitoral do passado tende a perpetuar a relação de forças entre os partidos. (SPECK, 2006, p.157)

Outra característica do financiamento político brasileiro que também tende a perpetuar a referida relação de forças é o fato de, desde 1995, os partidos políticos receberem recursos anuais direto do fundo partidário no valor aproximado de 1 real por eleitor, mantendo o padrão de favorecer quem já obteve melhores resultados no pleito anterior. 
campanhas. Aqui estão englobadas a necessidade de prestação de contas no que se refere à obediência à legislação vigente, bem como a prestação de contas sobre o emprego dos subsídios públicos. A divulgação de informações sobre o financiamento é importante, tanto para coibir ações ilegais quanto para possibilitar a fiscalização por parte dos demais competidores e pelos próprios eleitores. Além disso, alega-se que a maneira como os candidatos angariam fundos e os gastam, dá sinais de como será a gestão. De qualquer maneira, o principal argumento é o da necessidade de se possibilitar o voto informado. Poucos países conseguiram avançar na produção e divulgação de informações sobre o financiamento antes das eleições. No caso do Brasil, o avanço neste setor foi grande desde o escândalo envolvendo o então Presidente da República, Fernando Collor de Mello e seu coordenador de campanha, Paulo César Farias. Este avanço pode ser observado na Lei Eleitoral de 1997 que

obriga os candidatos e partidos a prestarem contas de forma detalhada sobre a origem e destino dos recursos utilizados na campanha. As doações são identificadas individualmente, incluindo nome dos doadores, o código da Receita Federal (CNPJ/CGC) e a data da doação. Também é obrigatório registrar as doações em espécie, estimando o seu valor em dinheiro. Todos os recursos de campanhas devem ser administrados em uma conta bancária única de cada candidato. A Justiça Eleitoral, responsável pela organização do processo eleitoral, completou este sistema com a introdução da prestação de contas sobre o financiamento em formato eletrônico e a divulgação de dados para a sociedade. (SPECK, 2006, p.158) 
No Brasil, em 2005, escândalos políticos tiveram forte vinculação ao tema do financiamento político. Parte deste escândalo se deve à prestação de contas incompleta por parte de partidos e candidatos. Este problema nos remete ao já debatido "caixa dois", e à questão da falta de fiscalização e punição. Apesar dos problemas referentes ao "caixa dois", observamos que os dados referentes ao "caixa um" nos fazem crer que a fiscalização por parte da sociedade e da imprensa tornou-se algo real, haja visto o valor declarado nas eleições de 2002 e 2004, que girava em torno de 1 bilhão de reais. De qualquer modo, para que a transparência fosse verificada de maneira mais efetiva no que se refere ao financiamento de campanhas, seria necessário que os dados, além de detalhados, fossem divulgados durante as campanhas.

De maneira geral, observamos que as críticas às diferentes modalidades de financiamento político têm por referência, sobretudo, o combate à corrupção. Neste cenário destaca-se o sistema misto como sendo o mais adequado às democracias contemporâneas. O sistema de financiamento "ideal" deveria agregar os pontos positivos do financiamento público e do privado, ou seja, deveria agregar a garantia de um certo nível de financiamento a todos os partidos; a redução do poder de pressão por parte dos grupos de interesse; o estímulo ao enraizamento dos partidos na sociedade e a possibilidade de os candidatos e partidos se comunicarem de maneira satisfatória com os eleitores. Por outro lado, este sistema deveria anular ou, ao menos, minimizar os efeitos negativos de ambas as formas de financiamento quais sejam, a dificuldade de definir quanto deve ser distribuído a cada 
partido; o problema da legitimação do emprego de altos valores para o financiamento político em países que passam por dificuldade econômica; as diversas formas de corrupção; e, sobretudo, a questão da influência dos grupos de interesse através do uso do dinheiro com o objetivo de comprar acesso e, principalmente, influência.

Desta maneira, devemos desenvolver e/ou fortalecer mecanismos que venham assegurar que um sistema misto, nos moldes aqui propostos, possa ser implementado. Isso implica a necessidade, como já foi dito, de se desenvolver e/ou fortalecer uma instituição responsável pela fiscalização e com poderes de sanção. Trata-se, também, de se providenciar reformas no sistema financeiro e no sistema tributário, intimamente atrelados ao financiamento político ${ }^{55}$. Ademais, é necessário o fortalecimento de uma cultura política de vigia e cobrança na sociedade, tanto dentre políticos e candidatos quanto dentre financiadores e eleitores. Deste modo, poderemos vislumbrar a possibilidade de um sistema de financiamento político mais justo e igualitário.

A maneira através da qual essa cultura política de cobrança na sociedade possa se verificar, bem como que instituição ou instituições deveriam ser desenvolvidas e/ou fortalecidas com o intuito de se fiscalizar e punir irregularidades, são temas que exigem maior reflexão.

\footnotetext{
${ }^{55}$ Como já foi dito anteriormente, sobre isso, Samuels (2003, p.385) aponta a criação da CPFM e a prerrogativa do governo para quebrar o sigilo bancário como importantes avanços na capacidade do governo de vigiar as transações financeiras e detectar possíveis fraudes.
} 


\section{Considerações finais}

Em linhas gerais, podemos concluir que a teoria da justiça aponta para o aspecto moral da política. O que é justo, politicamente falando? O que é desejável? Uma das observações mais decorrentes é a de que, ao contrário do que muitas vezes crê o senso comum, o regime democrático nem sempre produz resultados justos. Muito pelo contrário, um dos grandes desafios de cientistas políticos por todo o mundo é, exatamente, o de sugerir meios através dos quais o método democrático possa vir a produzir resultados mais justos.

Em sua obra, Rawls nos chamou a atenção para a importância das liberdades políticas inseridas no primeiro princípio de justiça. As liberdades políticas, e somente elas, deveriam possuir um valor eqüitativo. Ele diz que

\footnotetext{
"o valor eqüitativo das liberdades políticas garante que cidadãos similarmente dotados e motivados tenham praticamente uma chance igual de influenciar a política governamental e de galgar posições de autoridade, independentemente de sua classe social e econômica." (RAWLS, 2003, p.65)
}

Em outras palavras, diferenças de ordem econômica não podem alterar a capacidade dos cidadãos de influenciar as políticas e nem influenciar a postura dos mesmos frente ao processo político. Porém, devido à percepção de que os custos da participação no processo político (dentre eles o emprego de tempo para informar-se) são demasiadamente altos, tendo em vista a sensação de que quem realmente influencia o processo político são os detentores de recursos financeiros, o auto-respeito dos cidadãos abala-se devido à idéia de 
impotência frente às forças econômicas envolvidas no processo. A questão da distribuição desigual de recursos políticos cruciais é preponderante nesta questão dos níveis desiguais de participação, e requer um maior esforço no sentido de expandir as oportunidades, tanto sob o ponto de vista político quanto social. A redistribuição de renda e o ambiente propício ao desenvolvimento de uma cultura política favorável à participação política são, sem dúvida, algumas das maiores preocupações referentes à democracia moderna.

Dentro deste grande tema, ganha espaço a questão do financiamento de partidos políticos e campanhas eleitorais. Ian Shapiro identifica o financiamento político como sendo um ponto muito importante do mecanismo da oferta de políticas de natureza redistributiva, e aponta a importância do estabelecimento de um limite às contribuições feitas por pessoas físicas e jurídicas dentro deste processo. John Rawls aponta o financiamento político como sendo um dos arranjos institucionais que podem ser eficientes para se pensar a manutenção do valor eqüitativo das liberdades políticas e para que os resultados do processo democrático sejam mais justos, através, neste caso, do financiamento público exclusivo, além do estabelecimento de limites às contribuições de pessoas físicas e jurídicas, bem como o controle dos gastos de campanha (VITA, 2003, p.125), com o objetivo de se erguer barreiras entre o poder econômico e o poder político. Robert Dahl, por sua vez, nos chama a atenção para o fato de a igualdade política ser possível somente numa democracia representativa. Dentre as maneiras através das quais podemos avançar rumo à ampliação das igualdades políticas e, com isso, rumo a um processo político ideal, Dahl nos aponta a reforma do financiamento político.

Quando pensamos em mecanismos que possibilitem trazer maior justiça ao processo político, é pertinente observar se o regime político em vigor está capacitado a abarcar tais mecanismos. No caso da discussão à que esta dissertação se propôs - em torno do 
financiamento político - é importante nos questionarmos acerca da representação política, uma vez que, sem representação não haveria financiamento de partidos e campanhas. Os defensores da democracia direta tecem críticas ferrenhas à democracia representativa, no que se refere à sua incapacidade em fazer valer o ideal democrático de "governo do povo, pelo povo". Porém, ao analisarmos a representação desde sua origem, observamos que ela se encontra presente, mesmo nas assembléias da Grécia antiga. Logo, a representação confunde-se com a própria história da democracia. Analisando Bernard Manin, chegamos à conclusão de que a democracia representativa, não somente é superior à democracia direta, como também não está passando por uma crise, mas sim por uma transformação. Porém, quatro elementos que são considerados pilares do governo representativo, mantiveram-se presentes desde a origem da democracia representativa. Sendo assim, uma vez comprovada a superioridade da democracia representativa e a ausência de uma crise da representação, bem como o fato de o sistema democrático representativo ser considerado o ideal para a realização da igualdade política, dei continuidade ao estudo acerca do financiamento político, tendo em vista a manutenção do valor eqüitativo das liberdades políticas.

Realizei uma análise da bibliografia empírica sobre o tema do financiamento de partidos políticos e campanhas eleitorais com o objetivo de encontrar o endossamento ou não às propostas para o financiamento político estabelecidas pelos teóricos da justiça e da democracia.

Tendo em vista o fato de a competição política necessitar de recursos financeiros para ser colocada em prática, o dinheiro é necessário para que a democracia representativa se dê de maneira eficaz. Porém, o financiamento de partidos políticos e campanhas eleitorais abarca uma série de críticas, decorrentes desta prática, sendo que a crítica com a qual me preocupei nesta dissertação diz respeito, sobretudo, "à subversão do princípio da 
igualdade dos cidadãos quanto à sua influência sobre a representação política" (SPECK, 2006, p.155).

Analisando os argumentos favoráveis e desfavoráveis a cada uma das modalidades de financiamento hoje existentes, quais sejam, o financiamento público, o financiamento privado e o financiamento misto, chegamos a algumas conclusões: o financiamento público, apesar de extremamente favorável ao processo democrático, por garantir um nível de financiamento para todos os partidos políticos, independentemente de seus eleitores serem ricos ou pobres e por reduzir o impacto dos interesses econômicos na política, possibilitando uma competição mais eqüitativa, também possui pontos negativos, como o afastamento dos partidos políticos de suas bases, o que contribui para o enfraquecimento dos já tão tênues laços entre eleitores e partidos políticos, além de estimular o situacionismo e o governismo. Aliado a isso existe o peso do fato de o financiamento público não garantir o fim do financiamento privado: as campanhas políticas são cada vez mais caras e sempre existiram pessoas físicas e jurídicas dispostas a contribuir, não havendo garantias de que este dinheiro não seja encaminhado até os partidos e candidatos através de práticas ilícitas de transferência de dinheiro e outros favorecimentos. Além disso existe o problema da legitimação, sobretudo em países subdesenvolvidos ou expostos a crises econômicas.

O financiamento privado, apesar de abarcar a principal crítica feita atualmente ao financiamento de partidos e políticos, qual seja, a ameaça da igualdade política pelo emprego abusivo do poder econômico, possui pontos positivos. Antes de mais nada, ao criticarmos o financiamento privado devemos ter em mente que ele não constitui um único bloco: ele possui segmentos. Em outras palavras, dentro do financiamento privado existem as contribuições de pequeno, médio e grande porte; contribuições feitas por poucos atores 
ou por muitos. As doações de pequeno porte, e até mesmo as de médio porte, feitas por vários atores é encarada como benéfica ao processo de representação política, sendo um meio legítimo de os eleitores apoiarem o partido ou candidato em questão, fortalecendo os laços entre eleitorado e partido político. O que ameaça o valor eqüitativo das liberdades políticas e afasta a justiça do processo democrático são as doações de grande porte feitas por poucos atores. É exatamente isso o que ocorre na maioria das democracias contemporâneas, especialmente no Brasil. Análises de dados referentes ao número de doadores e montantes doados mostram que as doações, além de se concentrarem nas mãos de poucos atores que fazem doações de grande porte, encontram-se, sobretudo, ligadas a setores econômicos especialmente vulneráveis à intervenção ou regulação governamental, como o setor financeiro (inclui bancos), o setor da construção (dominado por empreiteiras e outras firmas do setor da construção civil) e o setor da indústria pesada (como aço e petroquímicas) (SAMUELS, 2003a, p.372-376). Assim, observamos que a hipótese de John Rawls acerca da necessidade de se estabelecerem limites às contribuições encontra suporte na bibliografia empírica sobre o financiamento político.

O financiamento misto, por sua vez, aparece como o modelo ideal na opinião dos autores analisados (David Samuels, Delia Rubio, Bruno Speck, Daniel Zovatto). O desafio, aqui, seria o de possibilitar uma forma de financiamento que agregue os pontos positivos de ambas as formas anteriores de financiamento. Porém, é necessário que se tome providências para o financiamento misto não agregue, também, os pontos negativos das duas formas anteriormente mencionadas. Analisando, especificamente o caso do Brasil, algumas observações são pertinentes. A legislação brasileira deve ser repensada no que se refere ao estabelecimento de quem pode ou não fazer doações: enquanto sindicatos estão impedidos de doar (vale frisar que esta é uma herança do regime militar, não sendo esta 
proibição justificável de maneira convincente nos dias atuais), a legislação simplesmente se omite na questão das doações por parte de empresas que prestam serviços ou realizam obras para o Estado. É evidente os riscos decorrentes desta omissão, pois os riscos de troca de favores nesta situação são iminentes. Some-se a isso o fato de a iniqüidade social e econômica serem legalmente estabelecidas através do estabelecimento do limite de doação de $10 \%$ do faturamento bruto do ano anterior à eleição para pessoas físicas e $2 \%$ do faturamento bruto do ano anterior à eleição para pessoas jurídicas. É importante observar que existe um limite percentual, que varia de acordo com os rendimentos do doador, mas não existe um limite referente ao montante a ser doado, ou seja, quem fatura mais pode doar mais, quem fatura menos pode doar menos, independentemente do valor envolvido: a Lei Eleitoral apenas determina que os candidatos estipulem um gasto e o comuniquem à Justiça Eleitoral. Deste modo, concluímos que a bibliografia sobre financiamento político não corrobora com a hipótese do financiamento público exclusivo.

Um fator central dentro deste processo é a informação, tão importante para que a participação política se verifique de maneira satisfatória, pois é a partir dela que a possibilidade de accountability se dá. Numa democracia representativa, como a observada contemporaneamente, que em muito se assemelha à democracia do público definida por Bernard Manin, o accountability através do voto informado é crucial: num processo político onde a atuação do eleitorado é, basicamente, reativa, no sentido de responderem aos estímulos planejados pelos candidatos e governantes, tanto na hora de escolherem seus representantes quanto na hora de manifestarem seu apoio ou não ao governo cujo mandato chega ao fim (eleição e reeleição), a informação para a tomada de decisões dentro do processo político é primordial. A necessidade de transparência no que se refere ao financiamento político insere-se neste ponto: através desta transparência os eleitores 
poderão receber informações detalhadas a respeito da origem e fim dos recursos utilizados por partidos e candidatos, possibilitando uma avaliação mais eficiente daquele governo. No que se refere aos gastos de campanha, existe o argumento de que a maneira como cada candidato emprega os recursos disponíveis oferece fortes indícios de como será seu governo. Daí a necessidade de que a prestação de contas ocorra e seja divulgada durante a campanha eleitoral $^{56}$.

A necessidade de um marco jurídico eficaz é crucial para que todos os pontos até aqui discutidos possam ser colocados em prática mas, aliado este marco jurídico, é preciso que haja um mecanismo de controle e aplicação de sanções independente, eficiente e institucionalmente fortalecido. No Brasil a instituição responsável pela fiscalização e sanção é a Justiça Eleitoral, através de seu órgão máximo, o Tribunal Superior Eleitoral (TSE) em conjunto com os Tribunais Regionais Eleitorais (TRE), com base em suas atribuições, determinadas pela Constituição e pelo Código Eleitoral. A Justiça Eleitoral e os Tribunais Eleitorais têm apresentado relativa eficácia no que se refere organização das eleições e na apuração dos resultados, graças a um sistema informatizado eficaz. Porém, quando se trata da questão do julgamento dos processos, a Justiça Eleitoral é morosa e, muitas vezes, ineficaz. Se a Justiça Eleitoral é capaz de personificar a instituição responsável pela fiscalização e sanção no processo político, se necessita de ajustes para

\footnotetext{
${ }^{56}$ A ONG Transparência Brasil confeccionou um relatório (ABRAMO, 2009) sobre o fato de os candidatos mentirem à Justiça Eleitoral. 65\%,dos parlamentares fizeram doações eleitorais, destes, 51\% foram candidatos, o que permite comprar os bens que declararam à Justiça eleitoral com as doações que fizeram. $11 \%$ dos parlamentares que também foram candidatos fizeram doações que superaram o total de bens que declararam possuir. Daí conclui-se que estes $11 \%$ mentiram: ou possuem mais bens do que declararam possuir, ou o dinheiro doado não é deles. O que propicia esse tipo de ocorrência é o fato de não haver obrigatoriedade de a declaração patrimonial entregue à Justiça Eleitoral seja a mesma entregue à Receita Federal. Além disso, não existe uma legislação que institua penalidade para quem fornece declarações falsas para a Justiça Eleitoral. Se este tipo de informação fosse veiculado durante as eleições, os eleitores teriam um importante instrumento de análise na hora do voto. Além disso, claro, a necessidade de uma legislação eficaz, associada a uma punição efetiva são evidentes, pois inibiriam esse tipo de ação.
} 
cumprir este papel com eficácia ou se não é a instituição ideal para tanto, é algo que exige maior reflexão.

Além disso, é necessário que se dissemine uma cultura política de transparência, tanto no meio político quanto no meio empresarial e dentre os cidadãos. Uma cultura de cobrança e de fiscalização é extremamente importante nas questões que envolvem prestações de contas, como é o caso do financiamento de partidos políticos e campanhas eleitorais. Além disso, com partidos políticos e eleitores atuando na vigilância e denunciando as possíveis irregularidades, a instituição responsável pela fiscalização não ficará tão sobrecarrega, impedindo que ilegalidades passem desapercebidas ou, ao menos, reduzindo o número de ilegalidades que passarão desapercebidas. É evidente que a disseminação de tal cultura política de transparência requer tempo e esforços conjuntos, sendo a maneira através da qual a disseminação desta cultura de transparência poderá se dar, outro ponto que exige maior reflexão.

Em resumo, a análise realizada nesta dissertação nos permite afirmar que, para que possamos avançar rumo à manutenção do valor eqüitativo das liberdades políticas, faz-se necessário:

- A existência de um financiamento de partidos políticos e campanhas eleitorais misto.

- A reforma da legislação. No caso do Brasil, esta reforma deve ser no sentido de estabelecer limites às contribuições com base em valores e não em porcentagens baseadas nos ganhos brutos do doador, estimulando a doação de pequenos montantes em detrimento de grandes somas; de repensar o veto aos doadores, permitindo que sindicatos, por exemplo, possam doar e impedindo que empresas 
ligadas que prestam serviços e ou realizam obras para o Estado doem; de definir mecanismos que estimulem empresas e partidos a tornar as informações referentes ao financiamento públicas.

- Alterações no que se refere às prestações de conta, que devem ocorrer durante as campanhas.

- A existência ou fortalecimento de um órgão independente, com poderes de fiscalização e sanção.

- A disseminação de uma cultura de transparência por toda a sociedade.

A análise aqui apresentada permite concluir que nossos esforços teóricos e empíricos devem ser menos no sentido de estabelecer uma outra forma de governo, que não a democracia representativa, e de definir outra forma de financiamento político, que não o misto e mais no sentido de apontar e aprofundar, como procurei fazer nesta dissertação, os pontos falhos da democracia representativa e, mais especificamente, do financiamento político, buscando soluções palpáveis para estas falhas. Somente assim caminharemos rumo a um processo democrático que possibilite a produção de resultados mais justos. 


\section{Referências bibliográficas}

ABRAMO, Claudio Weber. (2009) "Candidatos Mentem à Justiça Eleitoral”. Relatório. Transparência Brasil. [Consultado em 24/02/2009]. Disponível na Internet: http://www.excelencias.org.br/docs/doa2008.pdf] . (2005) “Às claras - um mapa do financiamento político nas eleições municipais brasileiras de 2004”. Transparência Brasil, janeiro [Consultado em 25/01/2009]. Disponível na internet:

http://www.transparencia.org.br/docs/mapa2004.pdf

ARAÚJO, Cícero. (2006) "Representação, retrato e drama" in Revista Lua Nova, São Paulo, nº7, pp. 229-260.

. (2002) "Democracia e justiça (ou liberalismo e neoliberalismo)". Trabalho apresentado no $3^{\circ}$ Encontro Nacional da Associação Brasileira de Ciência Política em jul. de 2002. [mimeo].

ARAÚJO, Caetano Ernesto Pereira. (2004) "Financiamento de campanhas eleitorais" in Revista de Informação Legislativa, Brasília, nº161, jan./mar., pp. 59-66. 
AYRES, Ian. (2001) "Should campaign donors be identified?" in Yale Law School John M. Olin Center for Studies in Law, Economics, and Public Policy Working Paper Series. Paper 257, pp.9-17. [Consultado em 12/12/2008]. Disponível na internet: http://www.ead.unicamp.br/ teleduc/cursos/diretorio/apoio_429_253///Ayres\%2020 01\%20Should\%20campaign\%20donors \%20be\%20identified.pdf

BOBBIO, Norberto. (2000) "Democracia Representativa e Democracia Direta" in O Futuro da Democracia. São Paulo: Ed. Paz e Terra.

; MANTEUCCI, Nicola \& PASQUINO, Gianfranco. (2000) Dicionário de Política. Brasília: Ed. UnB.

BRAGA, Maria do Socorro \& BOURDOUKAN, Adla. (2008) "Partidos políticos no Brasil: organização partidária, competição eleitoral e financiamento público". Trabalho apresentado no $32^{\circ}$ Encontro Anual da Anpocs. [mimeo]

\& PRAÇA, Sérgio. (2007) "Recrutamento partidário: seleção de candidatos à Câmara paulistana", in KINZO, Maria D’Alva Gil \& BRAGA, Maria do Socorro (Orgs.). Eleitores e representação partidária no Brasil, São Paulo: Associação Editorial Humanitas, pp 179-203.

BRESSER-PEREIRA, Luiz Carlos. (2006) "O paradoxo da esquerda no Brasil” in Novos Estudos Cebrap, São Paulo, nº74, mar., pp. 25-45. 
COHEN, Joshua. (1989) "Democratic Equality" in Ethics 99, Jul.

. (2003) "For a Democratic Society" in FREEMAN, Samuel (Org.). The Cambridge Companion to Rawls, Cambridge: Cambridge University Press, pp. 86-138.

COSTA, Florência \& VILAS, Juliana. (2004) “Transparência já - escândalos que envolvem operadores de campanha e fragilizam partidos tiram do forno reforma política" in Revista Isto É Independente, no 1795, 03/03/2004, [Consultado em 10/08/2007]. Disponível na internet: http://www.terra.com.br/istoe/1795/brasil/1795_tranparencia_ja_01.htm

DAHL, Robert A. (1989) Democracy and its critics. Yale: Yale University Press. . (2005) Poliarquia. São Paulo: Edusp. . (2006) On Political Equality. New Haven \& London: Yale University Press.

DOWNS, Anthony. (1999) Uma Teoria Econômica da Democracia. São Paulo: Ed. Edusp.

FLEISCHER, David. (2000) "Reforma política e financiamento das campanhas eleitorais" in Cadernos Adenauer, dez., nº10, pp. 79-104.

GALL, Norman. (2005) "Lula e Mefistófeles” in Braudel Papers, n³8. 
GONÇALVES, Bejamin. (2008) (Coord.) A responsabilidade social das empresas no processo eleitoral. São Paulo, Instituto Ethos e Transparency International.

KINZO, Maria D’Alva Gil. (2007) “Os partidos políticos no eleitorado: percepções políticas e laços partidários” in KINZO, Maria D’Alva Gil \& BRAGA, Maria do Socorro (Orgs.). Eleitores e representação partidária no Brasi, São Paulo: Associação Editorial Humanitas, pp 19-45.

KUCINSKI, Bernardo. (2007) "O valerioduto do PSDB” in Revista Brasil. Ed No 17, out. de 2007, [Consultado em 10/11/2007]. Disponível na internet:

http://www.revistadobrasil.net/rdb17/politica.htm

LAGO, Rudolfo. (2002) "Caixa dois amedronta o PT" in Correio Braziliense de 25/mai./2002, [Consultado em 10/11/2007]. Disponível na internet: http://www2.correioweb.com.br/cw/EDICAO_20020525/pri_tem_250502_197.htm

LANGBEIN, Laura I. (1986) "Money and Access: Some Empirical Evidence", in The Journal of Politics, vol. 48, nº 4, nov., pp. 1052-1062.

LAVAllE, Adrián G.; HOUTZAGER, Peter P. e CASTELlO, Graciela. (2006) "Democracia, pluralização da representação e sociedade civil” in Revista Lua Nova, São Paulo, nº7, pp. 49-103. 
MALBIN, Michael. (2008) "REALITY CHECK: Obama Received About the Same Percentage from Small Donors in 2008 as Bush in 2004 - Obama also raised 80\% more from large donors than small, outstripping all rivals and predecessors". CFI The campaing finance institute (affiliated with The George Washington University). 24 de nov. [Consultado em 20/12/2008]. Disponível na internet:

http://www.cfinst.org/pr/prRelease.aspx?ReleaseID=216

MANIN, Bernard; PRZEWORSKI, Adam \& STOKES, Susan C. (2006) "Eleições e representação" in Revista Lua Nova, São Paulo, nº7, pp. 105-138.

- (1997) The principles of representative government. Cambridge: Cambridge University Press.

. (1995) “As metamorfoses do governo representativo", in Revista Brasileira de Ciências Sociais, $\mathrm{n}^{\circ}$ 29, [Consultado em 14/06/2008]. Disponível na internet: http://www.anpocs.org.br/portal/publicacoes/rbcs_00_29/rbcs29_01.htm

MATAIS, Andreza. (2007) "PFL aprova mudança no nome para DEM e elege Rodrigo Maia presidente" in Folha Online, 28/03/2009, [Consultado em 14/01/2009]. Disponível na internet:

http://www1.folha.uol.com.br/folha/brasil/ult96u90718.shtml 
MELLO, Fernando Barros de \& BOMBIG, José Alberto. (2009) "Apoio ao voto obrigatório e à democracia é recorde" in Folha de São Paulo, domingo, 25/01/2009, p. A4.

MICHELMAN, Frank I. (2003) "Rawls on Constitutionalism and Constitutional Law" in The Cambridge Companion to Rawls, FREEMAN, Samuel (Org.). Cambridge: Cambridge University Press, pp. 394-425.

NOVARO, Marcos. (2000) Representación $i$ liderazgo em lãs democracias contemporâneas. Rosário: Homo Sapiens Ediciones.

OLIVEIRA, Francisco de. (2006) "O momento Lênin", in Novos Estudos Cebrap, São Paulo, nº75, jul., pp. 23-47.

POTTERS, Jan \& SLOOF, Randolph. (1996) "Interest groups: A survey of empirical models that try to assess their influence" in European Journal of Political Economy, vol. 12 , pp. 403-442.

Projeto de Lei n ${ }^{\circ} 2.679$ de 2003 da Comissão Especial de Reforma Política, alterando a Lei $\mathrm{n}^{\mathrm{o}} 4.737$ de 15 de julho de 1965 , a Lei nº.096 de 19 de setembro de 1995 e a Lei $\mathrm{n}^{\circ} 9.504$ de 30 de setembro de 1997.

RAWLS, John. (2003) Justiça como Eqüidade - uma Reformulação. São Paulo: Ed. Martins Fontes. 
. (2000) O Liberalismo Político. São Paulo: Ed. Ática.

. (1993) Uma Teoria da Justiça. Lisboa Editorial Presença.

RUBIO, Delia F. (2005). "Financiamento de partidos e campanhas - fundos públicos versus fundos privados" in Novos Estudos Cebrap, São Paulo, n73, nov., pp. 5-15.

SAMUELS, David. (2006) "Financiamento de campanhas no Brasil e propostas de reforma” in SOARES, Gláucio A. O. \& RENNÓ, Lucio R. (Orgs). Reforma política - lições da história recente. São Paulo: Editora FGV, pp. 133-153.

. (2003) "Financiamento de campanha e eleições no Brasil - o que podemos aprender com o 'caixa um' e propostas de reforma” in BENEVIDES, Maria Victoria et al. (Orgs). Reforma Política e cidadania. São Paulo: Fundação Perseu Abramo, pp.364-391.

SARTORI, Giovanni. (1982) Partidos e sistemas partidários. Brasília: Editora UnB.

SCHUMPETER, Joseph. (1988) Capitalismo, socialismo e democracia. São Paulo: Ed. Zahar.

SEN, Amartya. (2000) Desenvolvimento como liberdade. São Paulo: Cia das Letras. 
SHAPIRO, Ian. (2003) The State of Democratic Theory. Princeton: Princeton University Press.

. (1996) "Elements of Democratic Justice" in Political Theory, vol.24, nº4, novembro, pp: 579-619.

SMITH, Richard A. (1995) "Interest Group Influence in the U.S. Congress" in Legislative Studies Quarterly, vol. XX, nº 1, fev., pp. 89-139.

SPECK, Bruno W. (2006) "O financiamento de campanhas eleitorais" in AVRITZER, Leonardo \& ANASTASIA, Fátima, Reforma Política no Brasil. Belo Horizonte: Ed. UFMG, pp. 153-158.

. (2005) "Reagir a escândalos ou perseguir ideais? A regulação do financiamento político no Brasil”' in Cadernos Adenauer, ano 6, n² , pp. 123-159. [Consultado em 23/06/2006]. Disponível na internet:

http://bvc.cgu.gov.br/bitstream/123456789/1804/1/Speck05f.pdf

. (2004a) "Análisis comparativo sobre financiamento de campañas y partidos políticos. Brasil" in: Steven Griner \& Daniel Zovatto (Orgs.), De las normas a las buenas prácticas - El desafío del financiamiento político en América Latina, Organización de los Estados Americanos (OEA) y el Instituto Internacional para la Democracia y la Asistencia Electoral (IDEA), San José, Costa Rica , pp. 1-14, [Consultado em 13/05/2006]. Disponível na internet: 
http://paginas.terra.com.br/educacao/bws/91pub_p.html

. (2004b) "Brasil: Mitos, normas, y datos sobre la corrupción del proceso electoral por el financiamento político". Trábalho apresentado no Foro Latinoamericano Sobre Financiamiento de Partidos Políticos. Lima, 13 de outubro de 2004, Asociación Civil Transparencia, Lima, Perú, julio 2005, pp. 88-114, [Consultado em 13/05/2006].

Disponível na internet:

http://www.ead.unicamp.br/ teleduc/cursos/diretorio/apoio_429_253///Speck\%202 005\%20Brasil\%20-\%20Mitos,\%20Normas\%20y\%20Datos\%20\%5BPeru\%5D.pdf

. (2004c) "Campaign finance reform: is Latin América on the road to transparency?" in Global Corruption Report 2004, Transparency International, London (UK) and Sterling (VA/USA): Pluto Press, pp. 32-34, [Consultado em 16/05/2006]. Disponível na Internet:

http://paginas.terra.com.br/educacao/bws/91pub_p.html

. (2004d) "Cinco teses sobre o financiamento da competição política e a proposta da respectiva reforma" in Revista Jurídica Consulex, ano VIII, nº179, 30 de junho de 2004, pp. 35-37, [Consultado em 13/05/2006]. Disponível na internet: http://www.ead.unicamp.br/ teleduc/cursos/diretorio/apoio_429_253///Speck\%202 004\%20Cinco \%20teses\%20sobre\%20o\%20financiamento\%20\%5BConsulex \%201 $\underline{79 \% 5 \mathrm{D} . \mathrm{pdf}}$ 
(2004e) "La financiación política. Desafio para las democracias en los países de América". Trabalho apresentado no "Foro Hemisférico de la Sociedad Civil. Proceso de participación de la sociedad civil em la XXXIV Asamblea General de la OEA". Quito (Equiador), 26 e 27 de Abril de 2004, [Consultado em 13/05/2006]. Disponível na internet: http://paginas.terra.com.br/educacao/bws/91pub_p.html . (2004f) "Sobre a oportunidade, a modalidade e a viabilidade da Reforma Política" in Justilex, ano III, n²9, maio de 2004, pp. 32-34. [Consultado em 16/05/2006]. Disponível na internet: http://www.ead.unicamp.br/ teleduc/cursos/diretorio/apoio_429_253///Speck\%202 004\%20A\%20oportunidade, $\% 20 \mathrm{a} \% 20$ modalidade $\% 20 \mathrm{e} \% 20 \mathrm{a} \% 20$ viabilidade $\% 20 \mathrm{da}$ \%20reforma\%20pol\%edtica\%20\%5BJustilex\%5D.pdf . (2004g) "Teses sobre a reforma do financiamento político no Brasil" in Revista Jurídica Consulex, ano VIII, nº178, 15 de junho de 2004, pp. 32-34. [Consultado em 21/05/2006].

Disponível na internet:

http://www.ead.unicamp.br/ teleduc/cursos/diretorio/apoio_429_253///Speck\%202 004\%20Teses\%20Sobre \%20a\%20reforma\%20do\%20financiamento\%20pol\%edtico \%20\%5BConsulex\%20178\%5D.pdf (2004h) "Sobre a reforma do financiamento eleitoral" in Folha de São Paulo Coluna Opinião. São Paulo, 24 de março, [Consultado em 21/05/2006]. 
Disponível na internet:

http://www.ead.unicamp.br/ teleduc/cursos/diretorio/apoio 429 253///Speck\%202 004\%20Sobre $\% 20 \mathrm{a} \% 20$ reforma $\% 20 \mathrm{do} \% 20$ financiamento $\% 20$ eleitoral $\% 20 \% 5 \mathrm{BFol}$ $\underline{\text { ha\%2024mar04\%5D.pdf }}$

. (2003a) “O financiamento político no Brasil - normas e práticas vigentes" in Relatório de pesquisas para projeto comparativo da OEA/IDEA. São Paulo, julho, [Consultado em 22/05/2006]. Disponível na internet:

http://www.ead.unicamp.br/ teleduc/cursos/diretorio/apoio_429_253///Speck\%202 003\%200\%20financiamento\%20pol\%edtico\%20no\%20Brasil $\% 20 \% 5 \mathrm{BOEA}-$

$\underline{\text { IDEA\%5D.PDF }}$

. (2003b) "A integridade do financiamento de partidos e campanhas eleitorais levantamento sobre problemas enfrentados e sistemas regulatórios." Relatório para Transparency Internacional. São Paulo, junho de 2003.

STOKES, Susan C. (1998) "Pathologies of Deliberation" in Deliberative Democracy, Jon Elster (Org.). Cambridge: Cambridge University Press.

URBINATI, Nadia. (2006a) "O que torna a representação democrática?" in Revista Lua Nova, São Paulo, n67, pp. 191-228.

(2006b) Representative Democracy: principles and genealogy. Chicago: The University of Chicago Press. 
VALENTE, Rubens. (2007) "Bancada ruralista cresce 58\% e barra combate à escravidão" in Folha de São Paulo de 21/10/2007, [Consultado em 27/10/2007]. Disponível na internet: http://www1.folha.uol.com.br/fsp/brasil/fc2110200702.htm

VITA, Álvaro de. (2003). "Democracia deliberativa ou igualdade de oportunidades políticas?", in Novos Estudos Cebrap, São Paulo, N66, jul., pp. 111-128.

. (2000) “Democracia e justiça”, in Revista Lua Nova, São Paulo, nº50, pp. 5-23.

(1999). "Uma concepção liberal-igualitária de justiça distributiva", in Revista Brasileira de Ciências Sociais, Vol.14, N³9. Fevereiro 1999.

VON PARIJS, Philippe. (1995) “A justiça e a democracia são incompatíveis?”, in Estudos Avançados, №23, Vol. 9. Jan/Abr.

WALZER, Michael. (2003) Esferas da Justiça. São Paulo: Ed Martins Fontes.

WRIGHT, John R. (1990) "Contributions, Lobbyng, and Committee Voting in the U.S. House of Representatives" in The American Political Science Review, vol. 84, n², jul., pp. 417-438. 
ZOVATTO, Daniel. (2005) "Financiamento dos partidos e campanhas eleitorais na América Latina: uma análise comparada” in Opinião Pública, Campinas, vol. XI, nº 2, out., pp.287-336. 